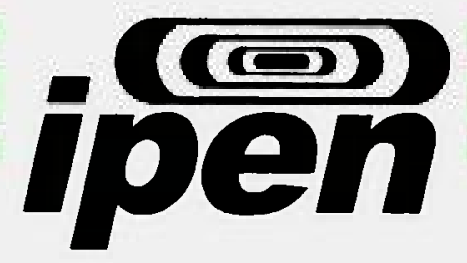

AUTARQUIA ASSOCIADA À UNIVERSIDADE DE SÃO PAULO

\title{
PROPOSTA DE IMPLANTAÇÃO DE UM SISTEMA DE GESTÃO AMBIENTAL NO LABORATÓRIO DE REJEITOS RADIOATIVOS DO IPEN-SP
}

\section{LUIZ ANTÔNIO ABDALLA DE MOURA}

Dissertação apresentada como parte dos requisitos para obtenção do Grau de Mestre em Ciências na Área de Tecnologia Nuclear - Aplicações.

Orientador:

Prof. Dr. Goro Hiromoto 


\section{(())}

ipen

INSTITUTO DE PESQUISAS ENERGÉTICAS E NUCLEARES

Autarquia associada à Universidade de São Paulo

PROPOSTA DE IMPLANTAÇÃO DE UM SISTEMA DE GESTÃO AMBIENTAL NO LABORATÓRIO DE REJEITOS RADIOATIVOS DO IPEN-SP

\section{LUIZ ANTÔNIO ABDALLA DE MOURA}

Dissertação apresentada como parte dos requisitos para obtenção do Grau de Mestre em Ciência na Área de Tecnologia Nuclear Aplicações.

Orientador:

Prof. Dr. GORO HIROMOTO

SÃo PAUlo 
DEDICATÓRIA

Dedico este trabalho à Andréa Márcia, pelo estímulo e apoio que ela sempre me passou para a realização deste trabalho, pelo seu carinho, amor e pela compreensão com todo o tempo utilizado em sua realização. 


\section{AGRADECIMENTOS}

Ao meu orientador, Prof. Dr. Goro Hiromoto, pelo apoio, amizade, paciência, conhecimento profundo na orientação e incentivo durante o curso e a realização deste trabalho.

Ao Centro Tecnológico da Marinha em São Paulo (CTMSP), pela oportunidade na realização do mestrado, em particular aos Almirantes Engenheiros Navais Alan Paes Leme Arthou e Carlos Passos Bezerril.

Aos Professores do IPEN em todas as matérias cursadas, que me deram uma base maior de compreensão dos problemas relacionados à radiação, aos rejeitos nucleares e à análise de risco.

Á minha grande amiga Ederli Mendes, que me auxiliou de maneira extremamente dedicada nas etapas finais de preparação deste texto. 
“ $A$ radiação ionizante é, ao mesmo tempo, benéfica e perigosa. Ela é usada para beneficiar a humanidade em medicina, pesquisa e indüstria. Porém, as pessoas ficam também apreensivas em relação à radiação. A natureza da radiação é tal, que nós não podemos vêla, senti-la, tocá-la, e isso assusta muitas pessoas."

Sommestad. L., Ministro do Meio Ambiente da Suécia. em 6.10.2003 


\title{
PROPOSTA DE IMPLANTAÇĀO DE UM SISTEMA DE GESTÃO AMBIENTAL NO LABORATÓRIOD E REJEITOS RADIOATIVOS DO IPEN-SP
}

\author{
Luiz Antônio Abdalla de Moura
}

\section{RESUMO}

Constata-se, atualmente, um uso crescente da energia nuclear no Brasil, para geração de eletricidade e outras aplicações (na medicina, na indústria, em agricultura, em técnicas ambientais, em radio-esterilização). Na realização das atividades de pesquisa do ciclo do combustível nuclear, em outras atividades de pesquisa, nas atividades industriais de produção de combustível e de energia e em todas as aplicações da energia nuclear, são gerados rejeitos radioativos, de atividades alta, média ou baixa. Atualmente, existem técnicas adequadas e seguras para o tratamento e armazenagem desses rejeitos, comentadas neste trabalho e que, sendo aplicadas, facilitam a aceitação da energia nuclear pela Sociedade.

Com a crescente preocupação com o meio ambiente, a Organização Internacional de Normalização preparou e emitiu a Norma ISO 14.001 - Sistemas de Gestão Ambiental, aplicável a todos os tipos e portes de organizações, visando a melhoria de seu desempenho ambiental. Seus requisitos foram detalhadamente comentados neste trabalho, sendo particularizados para a sua aplicação no Laboratório de Rejeitos Radioativos do IPEN, como um estudo de caso. 


\title{
PROPOSAL OF IMPLEMENTATION OF ENVIRONMENTAL MANAGEMENT SYSTEM THE LABORATORY OF RADIOACTIVE WASTE IN IPEN-SP
}

\author{
Luiz Antônio Abdalla de Moura
}

\begin{abstract}
An increasing use of nuclear technology in the form of its several applications (electricity generation, medical, industrial, agricultural, environment and radiosterilization) is currently being observed in Brazil. Radioactive waste of high, medium or lower activity is produced in all fuel cycle and other research activities, industrial activities of fuel production and electricity generation. Appropriate and safe technologies are available for the treatment and storage of radioactive waste and, when applied, contribute for the acceptance of nuclear energy by the Society.

With the increasing importance of demands related to environmental issues, the International Organization for Standardization issued the Standard ISO 14.001 Environmental Management System, applied to all types and size of organizations, helping them to increase their environment performance. In this research, the standard requirements were commented in detail, being particularized to the Laboratory of Radioactive Waste from IPEN, as a case study.
\end{abstract}




\section{SUMÁRIO}

Página

1 INTRODUÇÃO............................................................................................

1.1 As necessidades de energia no Brasil...................................................................

1.2 Energia Nuclear e Desenvolvimento Sustentável.................................................. 3

1.3 Outras aplicações da energia nuclear..................................................................... 6

1.4 Objetivos.............................................................................................

2 REJEITOS RADIOATIVOS.............................................................................. 9

2.1 Normas aplicáveis e definições................................................................................... 10

2.2 Tipos de rejeitos.........................................................................................

2.3 Classificação dos rejeitos radioativos................................................................ 16

2.4 Disposição de rejeitos radioativos........................................................................ 18

2.5 Novas tecnologias para reduzir a quantidade de rejeitos a estocar........................ 30

3 IMPLANTAÇÃO DE UM SISTEMA DE GESTÃO AMBIENTAL................. 32

3.1 Vantagens em melhorar o desempenho ambiental................................................... 32

3.2 Sumário da implantação de um sistema de gerenciamento ambiental................... 34

3.3 As etapas planejamento...................................................................................... 37

3.3.1 Política ambiental.......................................................................................

3.3.2 Recursos para implementação................................................................................ 43

3.3.3 Identificação de requisitos legais............................................................................

3.3.4 Aspectos e impactos ambientais....................................................................... 50

3.3.5 Objetivos e metas........................................................................................

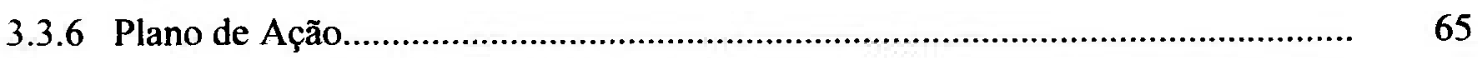

$3.4 \quad$ As etapas de execução...................................................................................... 66

3.4.1 Alocação de recursos financeiros..................................................................... 67

3.4.2 Funções, responsabilidades e autoridade............................................................... 68

3.4.3 Recursos humanos: competência, conscientização e treinamentos....................... 70

3.4.4 Comunicações.............................................................................................

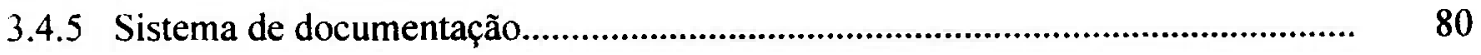

3.4.6 Controle operacional........................................................................................ 83

3.4.7 Preparação e resposta a emergências..................................................................... 84 
3.4.8 A cultura de segurança

3.5 As etapas de verificações e correç̃es.................................................................... 92

3.5.1 Monitoramentos e medições................................................................................. 93

3.5.2 Não-conformidades, aç̃es corretivas e ações preventivas..................................... 93

3.5.3 Registros................................................................................................... 97

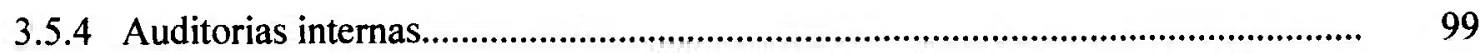

3.6 As etapas de avaliação..................................................................................... 101

4 PROPOSTA DE IMPLANTAÇÃO DE UM SISTEMA DE GESTÃo 103 AMBIENTAL NO LABORATÓRIO DE REJEITOS RADIOATIVOS DO IPEN

4.1 O Laboratório de Rejeitos Radioativos do IPEN....................................................... 103

4.2 Política Ambiental........................................................................................ 105

4.3 Comprometimento com a Política Ambiental.................................................... 106

4.4 Identificação dos aspectos e impactos ambientais.................................................. 107

4.5 Proposta de objetivos e metas.......................................................................... 113

4.6 Proposta de um Plano de Ação............................................................................. 113

4.7 Comunicações internas e externas..................................................................... 115

4.8 Conscientização e treinamento ........................................................................... 116

4.9 Estrutura de preparação e controle de documentos............................................... 118

4.10 Resposta em situações de emergência...................................................................... 120

4.11 Monitoração e medições................................................................................ 121

4.12 Controle de registros..................................................................................... 123

4.13 Indicadores de desempenho........................................................................ 124

4.14 Auditorias internas.......................................................................................... 125

4.15 Tratamento de não-conformidades................................................................ 139

5 PROGRAMAS DE GESTÃO ESPECÍFICOS............................................. 141

5.1 Gestão de resíduos sólidos comuns....................................................................... 141

5.2 Gestão do uso da energia........................................................................... 144

5.3 Gestão do uso de água.................................................................................... 145

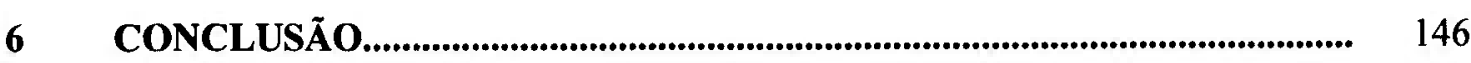

7 REFERÊNCIAS BIBLIOGRÁFICAS 


\section{LISTA DE TABELAS}

\section{CAPÍTULO 2}

Tabela 2.1 Classificação de rejeitos liquidos........................................................... 16

Tabela 2.2 Classificação de rejeitos sólidos.................................................... 17

Tabela 2.3 Classificação de rejeitos gasosos.................................................... 17

Tabela 2.4 Classificação de rejeitos liquidos com emissores alfa....................................... 17

Tabela 2.5 Classificação de rejeitos sólidos com emissores alfa........................................... 18

Tabela 2.6 Rejeitos produzidos por uma central nuclear de $1000 \mathrm{MWe}$ operando durante 1 ano............................................................... 19

\section{CAPÍTULO 3}

Tabela 3.1 Categorias de gravidade dos impactos ambientais............................ 54

Tabela 3.2 Niveis de freqüência ou probabilidade de ocorrência........................ 54

Tabela 3.3 Treinamentos recomendados......................................................... 72

Tabela $3.4 \quad$ Ficha de registro de treinamentos................................................. 74

\section{CAPÍTULO 4}

Tabela 4.1 Planilha de controle de fluxogramas de processo............................ 109

Tabela 4.2 Planilha de avaliação dos impactos ambientais................................ 111

Tabela 4.3 Plano de ação............................................................................. 114

Tabela 4.4 Plano de monitorações e medições.................................................. 123

Tabela 4.5 Modelo de Relatório Interno de Auditoria........................................ 136

Tabela 4.6 Modelo de Relatório de Acompanhamento de Auditoria................. 137

Tabela 4.7 Relatório de Não-Conformidade Ambiental..................................... 138 


\section{LISTA DE FIGURAS}

\section{CAPÍTULO 1}

Figura 1.1 Fontes de geração de energia elétrica no mundo............................... 2

Figura 1.2 Fontes de geração de energia elétrica no Brasil ................................. 2

Figura 1.3 Visão noturna da Terra e distribuição de plantas nucleares.................. 5

\section{CAPÍTULO 2}

Figura 2.1 Barreiras para o material radioativo.

Figura 2.2 Calor gerado por diferentes elementos radioativos em combustível nuclear queimado.

Figura 2.3 Radioatividade produzida pelos produtos de fissão de um CNQ, em função do tempo.

Figura 2.4 Casco de aço com aletas para armazenagem de CNQ........................ 25

Figura 2.5 Armazenamento de superficie de combustível nuclear queimado....... 25

Figura 2.6 Silos verticais de concreto armado para armazenagem de combustivel nuclear queimado.

Figura 2.7 Armazenagem de rejeitos radioativos de alta atividade em poços (em Hanford, USA - foto à esquerda) e Cascad, na França - foto à direita).

Figura 2.8 Entrada Sul do depósito de Yucca Mountain, USA........................... 28

Figura 2.9 Centro de Armazenamento de Rejeitos de Média e Baixa Atividade de El Cabril, Espanha...

Figura 2.10 Contêineres de armazenagem de rejeitos de baixa atividade em Drigg (UK) (à esquerda) e em tambores na França (à direita).

\section{CAPÍtulo 3}

Figura 3.1

Ciclo PDCA

PDCA aplicado a um Sistema de Gestão Ambiental.

Formulário sugerido para identificação dos requisitos legais

Figura 3.3

Figura 3.4

Figura 3.5

Figura 3.6

Figura 3.7

Figura 3.8
Diagrama de Ishikawa.

Matriz de Risco

Planilha de avaliação dos impactos ambientais. Análise de riscos.

Etapas de uma análise de riscos quantitativa. 


\section{CAPÍTULO 4}

Figura 4.1 Fluxograma de processo de tratamento de sólidos compactáveis.. 108 


\section{LISTA DE ABREVIATURAS}

ABNT - Associação Brasileira de Normas Técnicas

AIEA - Agência Internacional de Energia Atômica

ANEEL - Agência nacional de Energia Elétrica

ARAMAR - Centro Experimental ARAMAR da Marinha

CDTN - Centro de Desenvolvimento da Tecnologia Nuclear

CETESB - Companhia de Tecnologia de Saneamento Ambiental

CIPA - Comissão Interna de Prevenção de Acidentes

CNEN - Comissão Nacional de Energia Nuclear

CTMSP - Centro Tecnológico da Marinha em São Paulo

IAEA - International Atomic Energy Agency

IBAMA - Instituto Brasileiro do Meio Ambiente e dos Recursos Naturais Renováveis

IBGE - Instituto Brasileiro de Geografia e Estatística

I.C.R.P. - International Commission on Radiological Protection

IEN - Instituto de Engenharia Nuclear

INB - Indústrias Nucleares do Brasil

IPEN - Instituto de Pesquisas Energéticas e Nucleares

LABGENE - Laboratório de Geração Núcleo Elétrica em ARAMAR

ISO - International Organization for Standardization

LRR - Laboratório de Rejeitos Radioativos

SGA - Sistema de Gestão Ambiental

SMA - Secretaria do Meio Ambiente

ONGs - Organizações Não-Governamentais

TQC - Total Quality Control 


\section{LISTA DE SÍMBOLOS}

$$
\begin{aligned}
& \mathrm{Bq} \text { - becquerel } \\
& \mathrm{Ci} \text { - curie } \\
& \mathrm{CO}_{2} \text { - dióxido de carbono } \\
& \mathrm{h} \text { - hora } \\
& \mathrm{kg} \text { - quilograma } \\
& \mathrm{m} \text { - metro }
\end{aligned}
$$$$
\text { MWe - megawatt elétrico }
$$$$
\mathrm{R} \text { - rem }
$$ 


\section{INTRODUÇÃO}

\subsection{As necessidades de energia no Brasil}

O Brasil, como se observa por meio de indicadores sócio-econômicos, é um país com enormes carências. E, para conseguir melhorar a qualidade de vida de grande parte de sua população, precisa aumentar as suas taxas de crescimento econômico, gerando emprego e renda, incorporando uma grande parcela de sua população ao consumo e proporcionando melhores condições de vida. E, para se desenvolver, o país precisa de energia, obtida de forma econômica, confiável e cuja produção seja aceitável do ponto de vista ambiental.

A utilização da energia está diretamente associada à qualidade de vida de um povo. Necessitamos de energia, durante praticamente todo o tempo de nossa existência, sob as formas de eletricidade, combustíveis para transporte, aquecimento ou refrigeração de alimentos, produção ou tratamento de água etc., sendo a energia um insumo importante em praticamente todos os produtos que consumimos.

Imaginemos uma pessoa que mora em um pais do terceiro mundo. Por exemplo, no Brasil, em uma propriedade rural no interior, longe de cidades. Para obter energia, ela usa lenha, precisa caminhar para realizar a coleta e, em seguida, transportar essa lenha com grande esforço físico. Com a queima da lenha, ela obtém somente energia térmica, para preparar alimentos (cozinhar) e, no máximo, um pouco de água quente para um banho com pouco conforto. Não pode dispor de refrigeradores para preservar alimentos. Não dispõe de TV, rádio, ar condicionado, banho quente com chuveiro. Ao usar a lenha, ela provoca danos à sua saúde por respirar fumaça (particulados e outros gases nocivos). Cerca de 2 bilhões de pessoas no mundo vivem assim, sem conforto quase nenhum, por não disporem de energia elétrica. Além de energia para uso doméstico, a indústria, o comércio e a área de transportes utilizam intensamente energia.

Pode-se dizer que um povo, para ter uma qualidade razoável de vida deve ter à sua disposição uma capacidade instalada de geração de energia elétrica de cerca de 1 KW por habitante. Aqui no Brasil, com aproximadamente 189 milhões de habitantes e cerca de 100.000 MW disponíveis, estamos muito abaixo desse valor ideal, estando disponível aproximadamente a metade (dados de junho de 2007, fontes IBGE e ANEEL). 
As figuras apresentadas, a seguir, mostram as fontes de geração de energia elétrica, no mundo (Figura 1.1) e no Brasil (Figura 1.2).

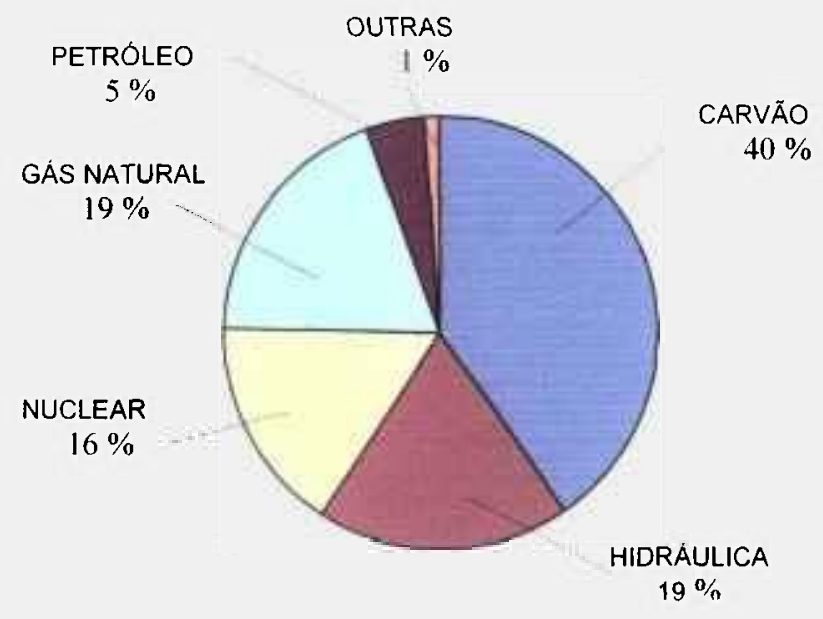

Figura 1.1 Fontes de geração de energia elétrica no mundo Fonte: Department of Energy USA. Energy Outlook 2007, May 2007

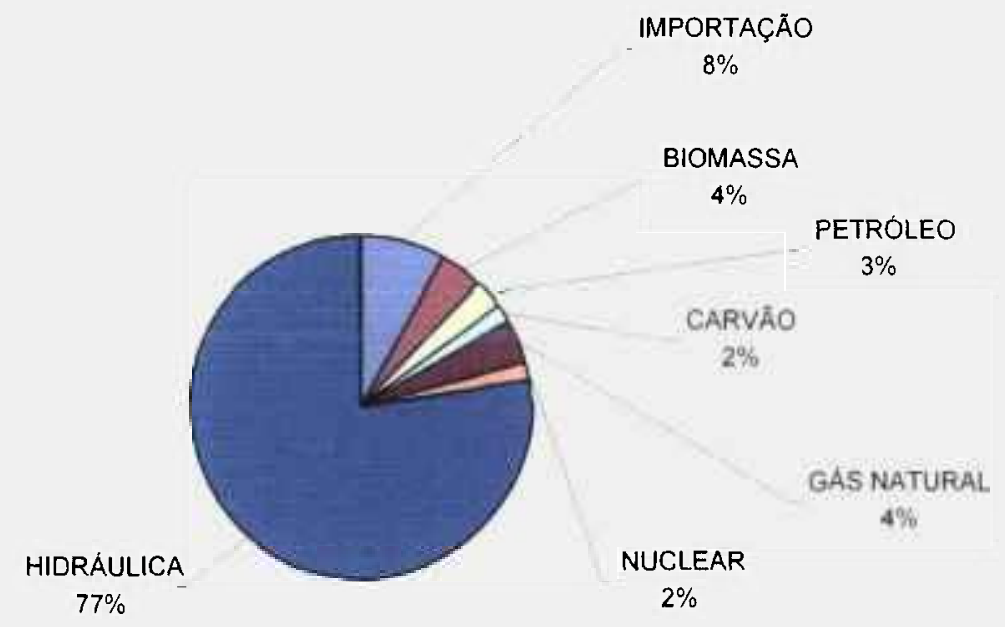

Figura 1.2 Fontes de geração de energia elétrica no Brasil Fonte: Balanço Energético Nacional 2005 (MME, 2005)

Verifica-se que, no Brasil, há uma dependência muito grande da energia de origem hidráulica, da ordem de $85 \%$ (soma da geração por fontes hídricas com a quantidade importada do Paraguai, gerada pela Usina de Itaipu). Apesar de ser considerada uma energia limpa, embora existam muitos impactos associados, a 
dependência elevada dessa forma de geração gera uma grande fragilidade para o país. Em 2002, por falta de chuvas, os reservatórios das usinas praticamente se esgotaram, levando a um difícil e oneroso programa de racionamento. Além disso, na região sudeste, que é a maior consumidora de energia, o potencial hidráulico foi praticamente esgotado, somente comportando pequenas centrais hidroelétricas (PCHs). Na Amazônia, onde há potencial, como se trata de uma planície, existiria a necessidade de formação de enormes reservatórios, alagando-se uma quantidade expressiva de terras, o que não é aceitável do ponto de vista ambiental. Além disso, para se transportar a energia gerada a longas distâncias, há uma perda considerável, além de custos elevados. A tendência atual é a de se construir usinas de fluxo, sem grandes reservatórios, porém em épocas de secas a vazão fica reduzida, comprometendo o fornecimento de energia (confiabilidade do sistema).

De acordo com a projeção do Intergovernmental Pannel on Climate Change (IPCC,2007), considerando as taxas médias de crescimento populacional, será necessário quintuplicar o fornecimento de energia para atender a demanda estimada até 2050 e, neste cenário, a contribuição da geração nucleoelétrica deverá aumentar significativamente (MOREIRA \& ABE, 2006).

Observamos que a energia nuclear pode vir a desempenhar um papel relevante, no futuro, para atender às necessidades do país.

\subsection{Energia Nuclear e Desenvolvimento Sustentável}

O modelo de desenvolvimento econômico a ser adotado no Brasil precisa, necessariamente, ser sustentável. E, entre as várias vertentes do desenvolvimento, existe a variável ambiental, ou seja, desenvolver respeitando os limites da natureza, sua capacidade de suporte, tanto em termos de uso dos recursos quanto do descarte de resíduos e outros sub-produtos gerados nos processos industriais. $\mathrm{O}$ relatório da Comissão Brundtland, formada pela Organização das Nações Unidas após a Conferência de Estocolmo, em 1972, definiu com precisão o conceito de desenvolvimento sustentável, qual seja, o de utilizarmos os recursos de que necessitamos no presente para atendimento de nossas necessidades, porém assegurando-se que as gerações futuras tenham condições de uso desses mesmos recursos, mantidas as condições de qualidade de vida no futuro (BRUNDTLAND, 1987). O relatório "Nosso Futuro Comum" cita: “Contudo, no fim, o desenvolvimento sustentável não é um estado de harmonia constante, mas, sim, um processo de mudança em que a utilização dos recursos, a 
dependência elevada dessa forma de geração gera uma grande fragilidade para o país. Em 2002, por falta de chuvas, os reservatórios das usinas praticamente se esgotaram, levando a um difícil e oneroso programa de racionamento. Além disso, na região sudeste, que é a maior consumidora de energia, o potencial hidráulico foi praticamente esgotado, somente comportando pequenas centrais hidroelétricas (PCHs). Na Amazônia, onde há potencial, como se trata de uma planície, existiria a necessidade de formação de enormes reservatórios, alagando-se uma quantidade expressiva de terras, o que não é aceitável do ponto de vista ambiental. Além disso, para se transportar a energia gerada a longas distâncias, há uma perda considerável, além de custos elevados. A tendência atual é a de se construir usinas de fluxo, sem grandes reservatórios, porém em épocas de secas a vazão fica reduzida, comprometendo o fornecimento de energia (confiabilidade do sistema).

De acordo com a projeção do Intergovernmental Pannel on Climate Change (IPCC,2007), considerando as taxas médias de crescimento populacional, será necessário quintuplicar o fornecimento de energia para atender a demanda estimada até 2050 e, neste cenário, a contribuição da geração nucleoelétrica deverá aumentar significativamente (MOREIRA \& ABE, 2006).

Observamos que a energia nuclear pode vir a desempenhar um papel relevante, no futuro, para atender às necessidades do país.

\subsection{Energia Nuclear e Desenvolvimento Sustentável}

O modelo de desenvolvimento econômico a ser adotado no Brasil precisa, necessariamente, ser sustentável. E, entre as várias vertentes do desenvolvimento, existe a variável ambiental, ou seja, desenvolver respeitando os limites da natureza, sua capacidade de suporte, tanto em termos de uso dos recursos quanto do descarte de resíduos e outros sub-produtos gerados nos processos industriais. $\mathrm{O}$ relatório da Comissão Brundtland, formada pela Organização das Nações Unidas após a Conferência de Estocolmo, em 1972, definiu com precisão o conceito de desenvolvimento sustentável, qual seja, o de utilizarmos os recursos de que necessitamos no presente para atendimento de nossas necessidades, porém assegurando-se que as gerações futuras tenham condições de uso desses mesmos recursos, mantidas as condições de qualidade de vida no futuro (BRUNDTLAND, 1987). O relatório "Nosso Futuro Comum" cita: “Contudo, no fim, o desenvolvimento sustentável não é um estado de harmonia constante, mas, sim, um processo de mudança em que a utilização dos recursos, a 
alocação dos investimentos, a orientação do desenvolvimento tecnológico e a mudança institucional são compatíveis com as necessidades futuras e presentes... As escolhas dolorosas são inevitáveis. Assim. em última análise, o desenvolvimento sustentável deve basear-se na vontade politica" (BRUNDTLAND, 1987).

A utilização do petróleo, carvão, gás natural e outros hidrocarbonetos não é uma solução sustentável, a longo prazo. Além dos recursos serem finitos, esgotáveis, geram efeitos deletérios, como, por exemplo, o aquecimento global e modificações climáticas resultantes das emissões de $\mathrm{CO}_{2}$. Muitos materiais perigosos são descarregados na natureza a partir de diferentes fontes, com baixo nível de controle.

Nesse contexto, a energia nuclear pode vir a desempenhar um papel relevante, complementando ou substituindo outras formas de energia, atendendo às necessidades da Sociedade.

O uso da energia nuclear, quando comparado a outras formas de energia, apresenta algumas vantagens (ainda pouco exploradas), no tocante ao conceito de desenvolvimento sustentável, aqui explorado em suas três vertentes (resultados econômico, ambiental e social):

- existe grande abundância desse combustível na Terra, disponível por muitos séculos, para atender às necessidades sociais;.

- segurança elevada, quando comparada com outras fontes de energia, observada pelo seu baixo histórico de acidentes (sobretudo quando comparável à exploração e uso de carvão);

- seu emprego causa baixo nível de poluição, com baixíssima colaboração para o aquecimento global do planeta;

- preserva o uso dos combustíveis fósseis para o uso de gerações futuras, em aplicações mais nobres que a simples queima;

- seus custos são competitivos em relação a outras fontes;

- seus rejeitos podem ser tratados, controlados com muito rigor e precisão, e armazenados com segurança por muito tempo.

Quando observamos uma fotografia noturna da Terra, apresentada à esquerda da Fig. 1.3, que foi montada com a superposição de fotos de satélites, é possível observar quais as regiões em que é maior o uso de eletricidade, que são as regiões mais iluminadas. Na parte direita da Fig. 1.3 é mostrada a distribuição de usinas nucleares, sendo possível concluir que, onde é maior a demanda de energia, foi necessário construir usinas nucleares para garantir esse suprimento. 

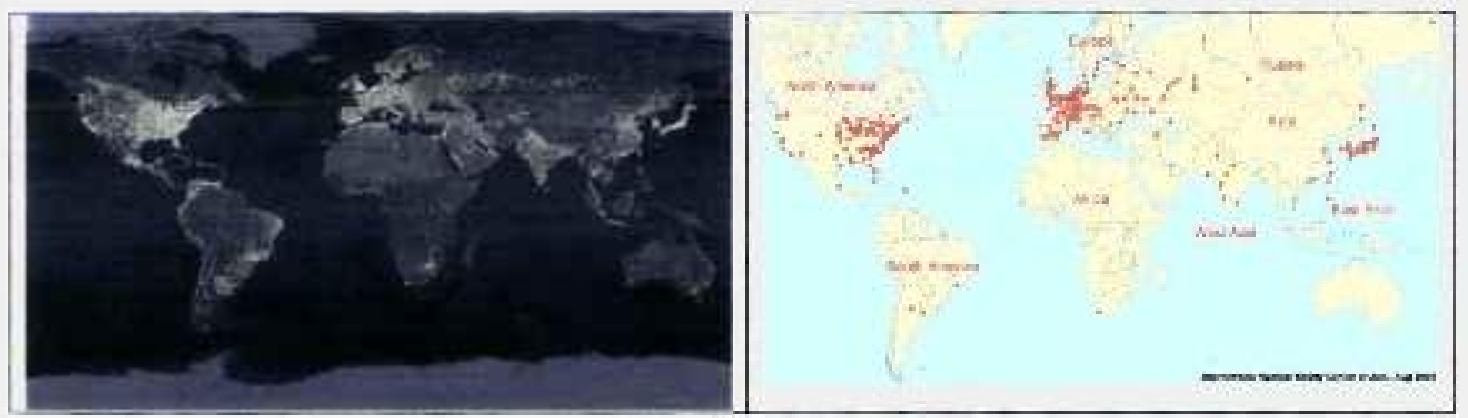

Figura 1.3 - Visão noturna da Terra e distribuição de plantas nucleares.

Fontes: NASA (2007) e International Nuclear Safety Center, 2005

O Brasil dispõe de grandes reservas de urânio (é o sexto país do mundo, com reservas comprovadas de 309 milhões de toneladas de concentrado de urânio), dispõe de tecnologia para a fabricação de combustível nuclear, dispõe de pesquisadores de nível elevado, dispõe de capacidade de projeto e capacidade industrial para a fabricação de componentes de usinas nucleares, e está, no momento, trabalhando em um projeto de um reator de pequeno porte para ser usado como um laboratório de geração núcleo elétrica (LABGENE).

As relações da energia com o meio ambiente são muito intensas. A produção de energia, seu transporte, sua armazenagem, sua distribuição e o próprio uso final, causam significativos impactos sobre o meio ambiente. Em particular, a energia nuclear causa impactos relacionados à radioatividade emitida pelos rejeitos e materiais contidos nas instalações.

Existem dois grandes problemas em ampliar o uso da energia nuclear, não somente no Brasil, mas também em muitos países do mundo: os riscos associados a uma usina nuclear e a questão dos rejeitos. Existe um risco inerente ao uso de material radioativo, referente aos perigos em operar uma instalação que contém fluidos e materiais em alta temperatura e alta pressão, porém esses riscos têm sido reduzidos, ao longo do tempo, graças a projetos cuidadosos, baseados em normas nacionais e internacionais bastante rigorosas.

A questão dos rejeitos e riscos associados à produção do combustível nuclear ganha relevância. sendo freqüentemente apontada como a principal causa da baixa aceitação pública à energia nuclear. Mesmo em aplicações médicas e outras aplicações, a palavra "nuclear" nem sempre é bem aceita. Basta ver que o nome "ressonância nuclear magnética" passou recentemente a ser apenas "ressonância magnética". Em alguns 
países, a irradiação de alimentos para esterilização é mencionada no rótulo como "alimento tratado por irradiação".

O desenvolvimento de novas técnicas de projeto, com o uso de ferramentas computacionais e análises de risco e de confiabilidade, o uso de novos materiais e processos de fabricação, são fatores que colaboraram para o aumento da segurança das instalações nucleares. A geração núcleo-elétrica também tem competitividade econômica quando comparada a outras formas de geração de energia elétrica, principalmente ao se considerar os limites de emissão de carbono e sua taxação, resultantes dos compromissos assumidos pelos países signatários do Protocolo de Kyoto. Todos esses fatores têm colaborado para aumentar a aceitação pública da atividade nuclear, inclusive entre participantes de ONGs anteriormente críticos ferrenhos da energia nuclear, como James Lovelock (ambientalista criador da hipótese de Gaia) e Patrick Moore, este sendo um dos fundadores do Greenpeace, que hoje a defendem por considerar a não emissão de gases causadores do aquecimento global.

O Painel Internacional para Mudanças Climáticas, patrocinado pela ONU, em reunião realizada em Bagkok, na Tailândia, em 4 de maio de 2007, divulgou em seu relatório intitulado "Mitigation of Climate Changes", projeções referentes às possibilidades de redução de emissões de $\mathrm{CO}_{2}$ e outros gases causadores do efeito estufa, citando a geração nuclear como uma das possibilidades a serem exploradas. (IPCC, 2007).

\subsection{Outras aplicações da energia nuclear}

A energia nuclear proporciona uma série de benefícios para a Sociedade, além da produção de energia:

a) dessalinização de água salgada do mar, para a produção de água doce. Existem regiões no Brasil onde é crítico o suprimento de água doce para as populações, como, por exemplo, em Recife, Pernambuco. A utilização de reatores nucleares para gerar energia elétrica e água, colocando-se trocadores de calor para atuar como evaporadores, pode ser uma solução interessante e econômica para produzir água doce.

b) Irradiação de alimentos. Trata-se de uma tecnologia, aprovada internacionalmente e utilizada em 37 países. Com a utilização de radiação nuclear (usualmente ${ }^{60} \mathrm{Co}$ ou feixe de elétrons), os alimentos são submetidos a doses que matam ou esterilizam bactérias e outros organismos patogênicos, aumentando-se a durabilidade dos alimentos. Essa técnica também evita o brotamento precoce de batatas, feijão e 
outros produtos, aumentando seu tempo de vida em prateleira. Entre as vantagens, podese citar que a aplicação da radiação não deixa resíduos nos alimentos (ao contrário da aplicação de alguns gases), é feita a frio, e com o produto já embalado.

c) aplicações na indústria, como gamagrafia de peças para detectar imperfeições e fissuras; esterilização de produtos farmacêuticos; beneficiamento de materiais poliméricos, melhorando as suas propriedades; controle de processo industriais, por meio da utilização de traçadores; aceleração da cura de tintas e vernizes; e melhoria da cor de algumas pedras preciosas;

d) aplicações em medicina, para diagnóstico e tratamento de doenças. Uso de radiofármacos, por exemplo, para diagnóstico e acompanhamento terapêutico no combate ao câncer; diagnose de doenças da tireóide, avaliações neurológicas e cardiológicas; análise de disfunções cérebro-vasculares; estudo do metabolismo cerebral nas doenças de Parkinson. Alzheimer e Tourettes.

e) uso em radioesterilização, irradiação de produtos sangüíneos destinados a transplantes, prevenindo possíveis rejeições; esterilização de tecidos humanos destinados a implantes; esterilização de válvulas cardiacas, rejeitos biomédicos, dispositivos contraceptivos intra-uterinos, preservativos masculinos e outros produtos e materiais descartáveis:

f) uso em meio ambiente. Os traçadores radioativos permitem estudar o metabolismo de plantas e o comportamento de insetos. Com isso, podem ser empregadas técnicas para eliminação de pragas por meio dos predadores naturais, sem o uso de inseticidas. Também é possível determinar a quantidade de agrotóxicos retida nos alimentos, além de identificar sua presença na água, solo e atmosfera. Radioisótopos permitem acompanhar o trajeto de poluentes no ar, no mar, nos rios ou no solo. Assim, são detectados danos ao meio ambiente que possam ser causados por agentes poluidores e rejeitos industriais. Também permitem determinar a permanência da água nos reservatórios de usinas hidroelétricas e mapear aqủiferos subterrâneos.

Entretanto, existem ainda muitas reações à plena utilização da energia nuclear, causada principalmente pela falta de informações acessíveis e confiáveis e desconhecimento do assunto. A radiação não pode ser detectada pelos nossos sentidos, o que aumenta o temor das pessoas em relação às instalações nucleares e aos usos da energia nuclear. Além disso, infelizmente, a energia nuclear foi apresentada à humanidade com as explosões de Hiroshima e Nagasaki, em 1945, esse fato pesando bastante na opinião pública, predispondo-a contra esse tipo de energia. Somente 
aumentando a necessidade de sua utilização (por exemplo, as utilizações na área médica são plenamente aceitas), controlando-se melhor os riscos e gerenciando-se os rejeitos de forma adequada, é que será possível melhorar a aceitação pública.

Em todas as formas de aplicação da energia nuclear, tanto na produção dos materiais (combustível e radioisótopos) quanto no uso da energia nuclear, são gerados rejeitos e são emitidas radiações ionizantes. Percebemos uma necessidade de se realizar esclarecimentos à população sobre a geração de radiação (fontes) e seus efeitos sobre o organismo, bem como sobre as formas de trabalho adequadas e medidas preventivas.

\subsection{Objetivos}

$\mathrm{Na}$ área empresarial, a partir de 1998, tem sido crescente a utilização da Norma Internacional ISO 14.001 - Sistemas de Gestão Ambiental, para se obter uma melhoria de desempenho ambiental, objetivando atender às demandas da Sociedade e dos Órgãos Ambientais. Dessa forma, aplicar esses conceitos em instalações que processam e armazenam rejeitos radioativos pode ser um fator de aumento de eficácia da gestão dessas instalações, reduzindo-se os riscos e colaborando para aumentar a aceitação da energia nuclear pela Sociedade.

Este estudo tem como objetivo propor sugestões para a implantação desta norma em instalações industriais e de serviços. Como um estudo de caso, aprofundando as sugestões de uma forma mais específica, é avaliada a aplicação dessa norma nas instalações do Laboratório de Rejeitos Radioativos do IPEN. 


\section{REJEITOS RADIOATIVOS}

Os rejeitos radioativos, produzidos como resultado das aplicações da energia nuclear, constituem-se em um dos principais fatores que inibem o crescimento do emprego da energia nuclear para geração elétrica, e do uso de radiaçð̃es ionizantes. Dessa forma, promover um melhor gerenciamento desses materiais irá se refletir em uma melhor aceitação da energia nuclear por parte do público leigo.

Ao longo das últimas décadas, foram realizados acordos internacionais para estabelecer regras a respeito dos cuidados com o manuseio de rejeitos radioativos, como a Convenção de 29 de setembro de 1997 (IAEA, 1997). Essa Convenção, denominada "Convenção Conjunta sobre Segurança no Gerenciamento de Combustível Nuclear Usado e sobre Segurança no Gerenciamento de Rejeitos Radioativos" foi aberta para assinaturas na sede da Agência Internacional de Energia Atômica em Viena. O Brasil assinou a Convenção em 11 de outubro de 1997 e ratificou-a por meio do decreto legislativo n. 1.019 de 14 de novembro de 2005, depositando o instrumento de ratificação no Depositário em 16 de fevereiro de 2006. Seu objetivo é alcançar e manter o alto nivel de segurança no gerenciamento de combustível nuclear usado e de rejeitos radioativos em todo o mundo. Uma das obrigações das Partes da Convenção é a preparação, a cada 3 anos, de um Relatório Nacional descrevendo as medidas tomadas a fim de cumprir os objetivos da Convenção, trabalho que vem sendo feito rotineiramente no Brasil, pela CNEN.

Rejeito radioativo é todo e qualquer material resultante de atividades humanas, que contenha radionuclídeos em quantidades superiores aos limites estabelecidos pela CNEN, cuja reutilização é imprópria ou não prevista (CNEN, 2001).

Atualmente, há três eixos de pesquisas referentes ao destino dos rejeitos nucleares:

a) separação e transmutação dos elementos radioativos, com reprocessamento para se produzir um novo combustível nuclear;

b) estocagem dos rejeitos em formações geológicas profundas ou em repositórios de sub-superfície; e

c) acondicionamento dos elementos radioativos e sua guarda por um período de tempo bastante longo. 


\subsection{Normas aplicáveis e definições}

Nesta seção, iremos apresentar as classificações atribuídas aos rejeitos, com base nas seguintes normas, estabelecidas pela Comissão Nacional de Energia Nuclear (CNEN), que são aplicáveis aos rejeitos radioativos, da sua origem ao destino final. Também são estabelecidos procedimentos em relação ao manuseio e armazenagem dos rejeitos:

NE - 6.05 - Gerência de Rejeitos Radioativos em Instalações Radiativas (CNEN, 1985);

NE - 6.06 - Seleção e Escolha de Locais para Depósitos de Rejeitos Radioativos (CNEN, 1989);

NN - 6.09 - Critérios de Aceitação para Deposição de Rejeitos Radioativos de Baixo e Médio Niveis de Radiação (CNEN, 2002a).

Os rejeitos são originários de unidades que produzem combustível nuclear (IPEN, CTMSP e INB), usinas como Angra I e Angra II, instalações que usam materiais radioativos, como clínicas, hospitais, indústrias, universidades, centros de pesquisa, entre outros. As normas citadas são aplicáveis a rejeitos de baixa e média atividade, que cobrem o escopo do presente trabalho.

Para efeito de gerenciamento, os rejeitos provêm de dois tipos de instalações (CNEN, 2001):

- as nucleares, que abrangem todas as instalações do ciclo do combustível, compreendendo a mineração do urânio; o beneficiamento; conversão; enriquecimento; reconversão; produção das pastilhas e elemento combustível; seu uso em usinas nucleares e armazenamento final:

- as radiativas, que são as demais instalações, como clínicas, hospitais, indústrias, universidades, centros de pesquisa etc.

As seguintes definições são aplicáveis: (CNEN, 2002a e 1985)

Acondicionamento - colocação de rejeitos radioativos em embalagem própria, visando cumprir os requisitos de segurança estabelecidos e minimizar os custos das etapas de gerenciamento posteriores.

Área Restrita - área sujeita a regras especiais de controle e supervisão e na qual as condições de exposição podem ocasionar doses equivalentes superiores a 1/10 (um décimo) dos limites ocupacionais para trabalhadores. 
Armazenamento - confinamento de rejeitos radioativos por um periodo definido.

Armazenamento Inicial - armazenamento temporário de rejeitos radioativos no espaço físico da instalação que os tenha gerado.

Deposição - colocação de rejeitos radioativos em instalação licenciada pelas autoridades competentes, sem a intenção de removê-los.

Depósito Intermediário - instalação licenciada pelas autoridades competentes e destinada a receber e, eventualmente, tratar e/ou acondicionar rejeitos radioativos até seu descarte ou remoção para o Repositório.

Depósito Provisório - instalação destinada a abrigar rejeitos radioativos provenientes de áreas atingidas por acidentes com materiais radioativos até sua transferência, para outro depósito, observando-se os requisitos de segurança estabelecidos pela CNEN.

Descontaminação - remoção ou redução da contaminação radioativa, com objetivo de reduzir a radioatividade a níveis estabelecidos pela CNEN.

Embalado - o conjunto formado pela embalagem e pelo seu conteúdo de rejeito.

Embalagem - recipiente fechado, com ou sem revestimento interno, que tem a finalidade de permitir o transporte e o armazenamento do produto e, se necessário, servir de barreira de engenharia com o objetivo de blindar a radiação e/ou reter radionuclídeos.

Estabilidade Estrutural - capacidade do produto ou do embalado de manter sua integridade física ao longo do tempo, isto é, suportar processos físicos e/ou químicos que possam resultar em sua decomposição e/ou degradação, ocasionando deformações, que levem a acomodações indesejadas dos materiais adjacentes e/ou sobrejacentes.

Exposição - irradiação intema ou externa de pessoas, com radiação ionizante.

Gerência de Rejeitos Radioativos (GRR) - Conjunto de atividades administrativas e técnicas envolvidas na coleta, segregação, manuseio, tratamento, acondicionamento, transporte, armazenamento, controle e deposição de rejeitos radioativos.

Instalação Radiativa (ou simplesmente Instalação) - estabelecimento onde se produzem, processam, manuseiam, utilizam, transportam ou se armazenem fontes de radiação. Excetuam-se desta definição:
a) as
Instalações
Nucleares
definidas
na
Norma
CNEN-NE-1.04, 
"Licenciamento de Instalações Nucleares" (CNEN, 2002b);

b) os veículos transportadores de fontes de radiação.

Material Explosivo - qualquer composto, mistura ou artigo que possa produzir uma substancial liberação de gás ou calor, com ou sem contato com chama ou faísca, provocando aumento repentino de volume.

Material Radioativo - material que contém substâncias emissoras de radiação ionizante.

Monitoração - medição de atividade ou de outras grandezas relativas à radiação, para fins de avaliação ou de controle de materiais radioativos ou de exposiçães, e para interpretação das medidas.

Programa de Controle de Processo (PCP): programa onde estão estabelecidos os parâmetros fundamentais de um determinado processo no âmbito da GRR, com o objetivo de atingir as faixas de valores aceitáveis com relação às propriedades e/ou requisitos de qualidade estabelecidos.

PGQ - Programa de Garantia da Qualidade

Produto - rejeito radioativo incorporado ou não em matriz sólida, ou seja, o rejeito tratado na sua forma final sem a embalagem.

Rejeito Radioativo (ou simplesmente Rejeito) - qualquer material resultante de atividades humanas, que contenha radionuclídeos em quantidades superiores aos limites de isenção especificados na Norma CNEN-NE-6.02, e para o qual a reutilização é imprópria ou não prevista. (CNEN, 1998).

Rejeitos de Baixo e Médio Niveis de Radiação - rejeitos contendo predominantemente, radionuclídeos emissores Beta e Gama com meia-vida da ordem de 30 anos, com quantidades de emissores alfa iguais ou inferiores a $3,7 \times 10^{3} \mathrm{~Bq} / \mathrm{g}$, e cujas taxas de calor não ultrapassem a $2 \mathrm{~kW} / \mathrm{m}^{3}$.

Repositório ou Depósito Final - instalação licenciada pelas autoridades competentes e destinada à deposição dos rejeitos, em observância aos critérios estabelecidos pela CNEN, os rejeitos radioativos provenientes de armazenamentos iniciais, depósitos intermediários e depósitos provisórios.

Segregação - separação dos rejeitos, de acordo com suas características fisicas, químicas, biológicas e radiológicas, de modo a facilitar a gerência.

Substância Pirofórica - qualquer substância ou material capaz de inflamarse e incendiar-se espontaneamente em presença de ar.

Trabalhador - pessoa que, em conseqúëncia de seu trabalho, possa receber, 
anualmente, doses superiores a 1/10 (um décimo) dos limites ocupacionais estabelecidos em normas da CNEN.

Transporte Externo - transporte de material radioativo realizado em áreas externas à instalação licenciada.

Transporte Interno - transporte de material radioativo realizado em áreas internas à instalação licenciada.

Tratamento - qualquer operação ou procedimento que modifique as características originais do rejeito radioativo (por exemplo, redução de volume, mudança da composição, remoção de radionudídeos), visando aumentar a segurança e minimizar os custos das etapas posteriones de sua gerência.

Em todas as etapas do ciclo de vida são necessários grandes cuidados ao ocorrer qualquer liberação no meio ambiente. Esses cuidados devem englobar todo o ciclo de vida do rejeito, desde a sua geração, em uma instalação nuclear ou radiativa, segregação dos diferentes tipos, sua coleta, transporte, tratamento, armazenamento e deposição final. Devem ser estudadas as concentrações e doses emitidas, as rotas percorridas pelos radionuclídeos, os usos que a população faz dos recursos naturais naquelas rotas, seus hábitos alimentares e de recreação, os tempos decorridos entre o lançamento e as exposições. Com esses dados, devem ser calculadas as doses resultantes. As liberações somente poderão ser autorizadas quando as doses forem suficientemente baixas, não representando riscos.

Quando não for possível ou adequada a liberação dos rejeitos para o meio ambiente, existem duas possibilidades de ação:

a) armazenamento por longo período de tempo, e

b) tratamento e destinação final dos rejeitos.

No primeiro caso, os rejeitos devem ser armazenados em condições controladas, por um período de tempo suficientemente longo para permitir o decaimento dos radionuclídeos presentes no rejeito, até que sejam atingidos níveis seguros de radiação para as pessoas e para o meio ambiente. $\mathrm{O}$ armazenamento implica no isolamento dos radionuclídeos e a restrição de sua liberação para o ambiente.

No segundo caso, os rejeitos são submetidos a modificações nas suas propriedades físicas e químicas, para que seja aumentada a segurança no transporte e destinação final, eventualmente isso resultando também em uma redução dos custos dessas etapas. 


\subsection{Tipos de rejeitos}

Os principais geradores de rejeitos no Brasil são:

a) usinas nucleares, que geram os seguintes tipos de rejeitos:

a1) rejeitos de baixo nível de atividade e vida curta: luvas, sapatilhas, aventais, máscaras, juntas, papéis e ferramentas contaminadas. São armazenados em tambores e, após o tempo de decaimento, podem ser considerados lixo comum, pois já não apresentam nenhum risco. As roupas contaminadas podem ser reutilizadas, sendo descartadas apenas quando a contaminação não possa ser retirada por lavagem (contaminação fixa).

a2) Rejeitos de médio nível de atividade e vida curta: resinas exauridas (usadas na remoção ou purificação da água contaminada), juntas e filtros utilizados para reter partículas radioativas. São acondicionados com a sua incorporação em matriz sólida por cimentação ou betuminização.

a3) Rejeitos de alto nivel de atividade e vida longa: elementos contidos nos combustíveis usados nos reatores nucleares que estejam exauridos. Nota: os combustíveis usados não são considerados como rejeito, pois podem ser reprocessados, gerando novos combustíveis. Embora o Brasil não realize o reprocessamento, há essa posição.

Os elementos combustíveis são removidos após uma permanência de 3 ou 4 anos dentro do reator. Em um primeiro estágio de gerenciamento, eles são armazenados em piscinas existentes no próprio reator, para que ocorra decaimento e resfriamento. Estes elementos combustíveis contém elementos radioativos com alto conteúdo energético (urânio e plutônio), que podem ser removidos, em instalações especiais, existentes em alguns países, para produzir um novo combustível. Além disso, são produzidos outros elementos (transurânicos e produtos de fissão), que se constituem em rejeitos de alta atividade e de vida muito longa.

Com base em dados obtidos na operação de usinas nucleares, uma usina como a de Angra 2 gera, anualmente, um volume entre 50 e $100 \mathrm{~m}^{3}$ de rejeitos de baixo e médio nivel de atividade (CNEN, 2001).

\section{b) Outras instalações do ciclo do combustível nuclear}

São as instalações que participam das várias fases da produção do combustível nuclear, cumprindo as seguintes etapas: a mineração e o beneficiamento do urânio produzindo-se o yellow-cake (concentrado de urânio, $\mathrm{U}_{3} \mathrm{O}_{8}$ ), também junto da 
mina, etapas realizadas no Brasil pelas Indústrias Nucleares do Brasil (INB), em Caetité, na Bahia; a conversão (técnica desenvolvida pelo Instituto de Pesquisas Energéticas e Nucleares (IPEN) e retomada pela Marinha com o projeto e a construção da Usina de Hexafluoreto de Urânio - USEXA, em Aramar); o enriquecimento do urânio, aumentando-se a concentração do isótopo ${ }^{235} \mathrm{U}$ (tecnologia desenvolvida pelo Centro Tecnológico da Marinha em São Paulo - CTMSP, utilizada em Aramar e na INB); reconversão, que consiste na transformação do $\mathrm{UF}_{6}$ enriquecido em $\mathrm{UO}_{2}$ (etapa realizada no Laboratório de Materiais Nucleares em Aramar e na INB); produção das pastilhas (em Aramar e na INB) e fabricação de elementos combustíveis (etapa realizada no Laboratório de Desenvolvimento de Instrumentação e Combustível Nuclear, do CTMSP, e na INB, em Resende). O ciclo do combustivel nuclear é completado com o uso do combustível em reatores nucleares e seu posterior armazenamento final, pois no Brasil não se realiza a etapa do reprocessamento.

Tais instalações armazenam temporariamente, ou de forma definitiva, os rejeitos gerados, no próprio sítio onde estão localizadas, seguindo normas de segurança estabelecidas pela CNEN.

É interessante lembrar a existência de rejeitos contendo elementos radioativos naturais, como urânio, tório e rádio, de atividade baixa, resultantes do tratamento de minerais, ou de trabalhos de desmantelamento de instalações que processavam esses materiais, como a antiga Usina de Santo Amaro, da Nuclemon.

\section{c) Hospitais, Clínicas e Institutos ou Centros de Pesquisa}

Os hospitais, laboratórios e clínicas que trabalham com material radioativo geram os seguintes rejeitos (CNEN, 2001):

c1) Equipamentos de radioterapia - Após o fim de sua vida útil, as fontes radioativas são substituídas e armazenadas em um dos três depósitos da CNEN. Com o objetivo de minimizar o volume de rejeitos no país, a CNEN orienta aos usuários que incluam nos contratos de aquisição de fontes, uma cláusula que garanta a devolução ao país de origem. Tratam-se de rejeitos de alta atividade e longo tempo de vida. São, normalmente, fontes de ${ }^{60} \mathrm{Co} \mathrm{ou}{ }^{137} \mathrm{Cs}$.

c2) Luvas, seringas, algodão, frascos e utensílios contaminados. Tratam-se de rejeitos de baixa atividade e vida curta. 
c3) Rejeitos biológicos, tais como tecidos humanos e de animais, carcaças de animais expostos à radiação, que são, em sua maior parte, compostos de matéria orgânica misturada a materiais radioativos. São rejeitos de atividade baixa e vida curta.

Os Institutos de Pesquisas geram rejeitos semelhantes ao das instalações do ciclo do combustível nuclear (luvas, aventais, filtros, ferramentas contaminadas), de atividade baixa e vida curta, armazenados nos próprios institutos.

\subsection{Classificação dos rejeitos radioativos}

Os rejeitos são classificados em categorias segundo o estado físico, natureza da radiação, concentração e taxa de exposição, conforme especificado na Norma CNEN-NE-6.05, itens 4.1 e 4.2 (CNEN, 1985):

\section{a) REJEITOS COM EMISSORES BETA/GAMA}

al) Rejeitos líquidos

Os rejeitos liquidos contendo emissores beta e/ou gama, e nos quais os eventuais emissores alfa tenham concentração total inferior a $3,7 \times 10^{8} \mathrm{~Bq} / \mathrm{m}^{3}\left(10^{-2} \mathrm{Ci} / \mathrm{m}^{3}\right)$, são classificados nas seguintes categorias, de acordo com os níveis de concentração, indicados na tabela 2.1:

Tabela 2.1 - Classificação de rejeitos liquidos

CATEGORIA

CONCENTRAÇÃO (c)

$$
\left(\mathrm{Bq} / \mathrm{m}^{3}\right) \quad\left(\mathrm{Ci} / \mathrm{m}^{3}\right)
$$

Baixo Nível de Radiação (LBN)

$\mathrm{c} \leq 3,7 \times 10^{10}$

$\mathrm{c} \leq 1$

Médio Nível de Radiação (LMN)

$3,7 \times 10^{10}<\mathrm{c} \leq 3,7 \times 10^{13}$

$1>\mathrm{c} \leq 10^{3}$

Alto Nível de Radiação (LAN)

c $>3,7 \times 10^{13}$

$c>10^{3}$

a2) Rejeitos Sólidos

Os rejeitos sólidos contendo emissores beta e/ou gama, e nos quais os eventuais emissores alfa tenham concentração total inferior a $3,7 \times 10^{8} \mathrm{~Bq} / \mathrm{m}^{3}\left(10^{-2}\right.$ $\mathrm{Ci} / \mathrm{m}^{3}$ ), são classificados nas seguintes categorias, de acordo com a taxa de exposição na superfície do rejeito, indicadas na tabela 2.2: 
Tabela 2.2 - Classificação de rejeitos sólidos

\begin{tabular}{lcc}
\hline \multicolumn{1}{c}{ CATEGORIA } & TAXA DE EXPOSIÇÃO (X) NA SUPERFICIE \\
\cline { 2 - 3 } & $\mu \mathrm{C} / \mathrm{kg} . \mathrm{h}$ & $\mathrm{R} / \mathrm{h}$ \\
\hline Baixo Nível de Radiação (SBN) & $\mathrm{X} \leq 50$ & $\mathrm{X} \leq 0,2$ \\
Médio Nível de Radiação (SMN) & $50<\mathrm{X} \leq 500$ & $0,2<\mathrm{X} \leq 2$ \\
Alto Nivel de Radiação (SAN) & $\mathrm{X}>500$ & $\mathrm{X}>2$ \\
\hline
\end{tabular}

a3) Rejeitos Gasosos

Os rejeitos gasosos são classificados nas categorias indicadas na tabela 2.3, de acordo com os níveis de concentração:

Tabela 2.3 - Classificação de rejeitos gasosos

\begin{tabular}{lcc}
\hline \multirow{2}{*}{ CATEGORIA } & \multicolumn{2}{c}{ CONCENTRAÇÃO $(\mathrm{c})$} \\
\cline { 2 - 3 } & $\left(\mathrm{Bq} / \mathrm{m}^{3}\right)$ & $\left(\mathrm{Ci} / \mathrm{m}^{3}\right)$ \\
\hline Baixo Nível de Radiação (GBN) & $\mathrm{c} \leq 3,7$ & $\mathrm{c} \leq 10^{-10}$ \\
Médio Nível de Radiação (GMN) & $3,7<\mathrm{c} \leq 3,7 \times 10^{4}$ & $10^{-10}>\mathrm{c} \leq 10^{-6}$ \\
Alto Nível de Radiação (GAN) & $\mathrm{c}>3,7 \times 10^{4}$ & $\mathrm{c}>10^{-6}$ \\
\hline
\end{tabular}

b) REJEITOS COM EMISSORES ALFA

b1) Rejeitos Líquidos

Os rejeitos líquidos contendo emissores alfa, em concentrações superiores a $3,7 \times 10^{8}$ $\mathrm{Bq} / \mathrm{m}^{3}\left(10^{-2} \mathrm{Ci} / \mathrm{m}^{3}\right)$ são classificados nas categorias indicadas na tabela 2.4 , de acordo com os niveis de concentração:

Tabela 2.4 - Classificação de rejeitos liquidos com emissores alfa

\begin{tabular}{|c|c|c|}
\hline \multirow{2}{*}{ CATEGORIA } & \multicolumn{2}{|c|}{ CONCENTRAÇÃO (c) } \\
\hline & $\left(\mathrm{Bg} / \mathrm{m}^{3}\right)$ & $\left(\mathrm{Ci} / \mathrm{m}^{3}\right)$ \\
\hline Alfa de Baixo Nível de Radiação (L $\alpha \mathrm{BN}$ ) & $3,7 \times 10^{8}<c \leq 3,7 \times 10^{10}$ & $10^{-2}<\mathrm{C} \leq 1$ \\
\hline Alfa de Médio Nível de Radiação (LaMN) & $3,7 \times 10^{10}<\mathrm{c} \leq 3,7 \times 10^{13}$ & $1<\mathrm{C} \leqq 10^{3}$ \\
\hline Alta de Alto Nível de Radiação (L $\alpha A N)$ & $c>3,7 \times 10^{13}$ & $c>10^{3}$ \\
\hline
\end{tabular}




\section{b2) Rejeitos Sólidos}

Os rejeitos sólidos contendo emissores alfa, em concentrações superiores a $3,7 \times 10^{8} \mathrm{~Bq} / \mathrm{m}^{3}\left(10^{2} \mathrm{Ci} / \mathrm{m}^{3}\right)$ são classificados nas categorias indicadas na tabela 2.5 , de acordo com os niveis de concentração:

Tabela 2.5 - Classifixacaño de rejeilux sólidos com enissores alta

\begin{tabular}{|c|c|c|}
\hline \multirow{2}{*}{ CATEGORIA } & \multicolumn{2}{|c|}{ CONCENTRAÇÃO (c) } \\
\hline & $\left(\mathrm{Bg} / \mathrm{m}^{3}\right)$ & $\left(\mathrm{Ci} / \mathrm{m}^{3}\right)$ \\
\hline $\begin{array}{l}\text { Alfa de Baixo Nível de Radiação } \\
(\mathrm{S} \alpha \mathrm{BN})\end{array}$ & $3,7 \times 10^{8}<\mathrm{c} \leq 3,7 \times 10^{11}$ & $10^{-2}<c \leq 10$ \\
\hline $\begin{array}{l}\text { Alfa de Médio Nível de Radiação } \\
\text { (SaMN) }\end{array}$ & $3,7 \times 10^{11}<\mathrm{c} \leq \leq 3,7 \times 10^{13}$ & $10<c \leq 10^{3}$ \\
\hline $\begin{array}{l}\text { Alfa de Alto Nível de Radiação } \\
\text { (SaAN) }\end{array}$ & $\mathrm{c}>3,7 \times 10^{13}$ & $\mathrm{C}>10^{3}$ \\
\hline
\end{tabular}

\subsection{Disposição de rejeitos radioativos}

A energia nuclear, por ser uma fonte muito concentrada de energia, e pelo fato de não existir "queima" (em seu sentido tradicional) gera uma quantidade muito pequena de resíduos, quando comparada a outras atividades industriais. Entretanto, em vista de sua periculosidade, esses resíduos precisam ser cuidadosamente armazenados e muito controlados, por muitos anos.

"Em termos de volume e peso de material, todo o setor nuclear, incluindo as usinas nucleares, hospitais, clínicas médicas e indústrias, produz muito menos rejeitos (lixo) que outras atividades industriais ou não-industriais. $O$ volume de rejeitos radioativos produzidos em um ano no mundo é aproximadamente $0,04 \%$ do volume total produzido de rejeitos de todos os tipos. Dos rejeitos radioativos, $95 \%$ referem-se a rejeitos de baixo ou médio nível de radioatividade, cujo tratamento e gerenciamento são de baixo custo e de pouca complexidade. Estes rejeitos são processados e necessitam ser armazenados em depósitos apropriados por alguns anos. A discussão, entretanto, está ligada aos $5 \%$ de rejeitos de alto nível de radioatividade, que precisam ser armazenados por milhares de anos para não causarem danos às pessoas" (Moreira e Abe, 2006).

Os rejeitos das atividades de mineração ficam retidos na própria mina e se caracterizam pela sua baixa atividade e grandes volumes.

Moreira e Abe (2006) apresentam uma tabela, reproduzida na Tabela 5.6, onde constam a quantidade ou o inventário de rejeitos gerados por uma central nuclear tipo PWR (Pressurized Water Reactor), operando com combustível de $\mathrm{UO}_{2}$ durante 
aproximadamente um ano. Os elementos provenientes principalmente da transmutação do urânio, denominados de transurânicos (plutônio e os actnídeos menores), representam a parcela mais perigosa dos rejeitos, sendo classificados como de alta atividade (HLW High Level Waste). Nessa mesma classificação foram enquadrados alguns produtos de fissão que possuem meia vida longa. Nesse mesmo trabalho, eles comentam, a título de comparação, que uma usina de geração de eletricidade com o uso de carvão, de porte semelhante à futura Usina Angra 3, libera para a atmosfera, em um ano, aproximadamente 2.000 toneladas de material particulado, 12.000 toneladas de compostos de enxofre, 6.000 toneladas de $\mathrm{NO}_{\mathrm{x}}$ e 8 milhões de toneladas de $\mathrm{CO}_{2}$ (Moreira e Abe, 2006).

Tabela 2.6 - Rejeitos produzidos por uma central nuclear de 1000 MWe operando durante 1 ano

\begin{tabular}{l|c}
\hline \multicolumn{1}{c|}{ Rejeitos } & Massa (kg) \\
\hline Plutônio & 288 \\
\hline Neptúnio e Amerício & 35 \\
\hline Produtos de fissão de meia vida longa & 120 \\
\hline
\end{tabular}

Os combustíveis nucleares usados, após serem retirados do reator, são constituídos, em média, em cerca de $95 \%$ de urânio residual, $1 \%$ de plutônio, $0,1 \%$ de elementos transurânicos e $4 \%$ de produtos de fissão (CEA, 2007).

Os elementos transurânicos presentes, também denominados de actinídeos menores, são o neptúnio (Np) e o amerício (Am).

Os produtos resultantes da fissão do ${ }^{235} \mathrm{U}$ e também do plutônio formado pelos isótopos 239 e 241 constituem a fonte mais importante de radioatividade do combustivel queimado, após sua descarga do reator. A maioria dos radionuclídeos perde a maior parte de sua radioatividade poucos anos após a irradiação, porém outros permanecem ativos por longo tempo. Entre os produtos de fissão, podem ser citados (CEA, 2007):

- os gases raros ( $\mathrm{Kr}, \mathrm{Xe})$;

- os alcalinos (Cs, $\mathrm{Rb})$;

- os alcalinos terrosos ( $\mathrm{Sr}, \mathrm{Ba}$ );

- o Ítrio (Y) e os lantanídeos; 
- o Se e o Te;

- os halogênios (incluindo o iodo)

-os metais nobres ( $\mathrm{Ru}, \mathrm{Rh}$ e o $\mathrm{Pd})$;

- outros elementos (Ag, Cd, Sn, Sb, In, Nd, Sm, Eu).

Romanato (2005), citando informações da AIEA, indica que, até 2003, foram geradas $2,5 \times 10^{5}$ ton de combustivel nuclear "queimado" nos reatores nucleares civis, restando cerca de $1,71 \times 10^{5}$ ton armazenadas, o restante tendo sido reprocessado.

Um dos maiores problemas relacionados à aceitação da energia nuclear refere-se à radiotoxicidade dos rejeitos radioativos produzidos nas centrais nucleares, que permanecem ativos por muito tempo.

"Os materiais que são ativados nos reatores nucleares, como as estruturas de aço no vaso do reator, requerem em torno de 100 anos para atingir níveis de radiação natural. Os produtos de fissão requerem cerca de 500 anos para atingir os mesmos níveis e os materiais transurânicos formados por plutônio, actinídeos menores (netúnio, amerício e cúrio) requerem na faixa de centenas de milhares de anos. Assim, a estratégia mais adequada é tratar os elementos transurânicos para reduzir de forma significativa a quantidade desses rejeitos" (Moreira e Abe, 2006).

A AIEA publicou em 1995 uma Safety Series (IAEA, 1995), em que ela estabelece nove princípios relacionados ao gerenciamento de rejeitos radioativos, que devem ser isolados do meio ambiente. Um deles orienta que "os rejeitos radioativos deverão ser gerenciados de tal modo que não imponham ônus indevidos para as futuras gerações". Como princípio ético, as gerações que receberem os benefícios da atividade deverão também assumir as responsabilidades decorrentes da atividade, neste caso cuidar dos rejeitos radioativos de forma eficiente. As tecnologias atualmente disponíveis podem garantir que os rejeitos radioativos podem ser armazenados de modo que haja proteção à saúde e segurança das pessoas e do meio ambiente.

O combustível nuclear queimado não é considerado um rejeito. No futuro, com a crescente escassez de disponibilidade de outras fontes de energia, haverá interesse em realizar uma "reciclagem" desse material. Atualmente, já existem muitas pesquisas no sentido de fabricar novos combustíveis com esse reaproveitamento, o que será comentado mais adiante neste trabalho. Com certeza existirão tecnologias para processamento de forma segura e economicamente viáveis. Entretanto, pela importância 
do tema e, por existir no público leigo uma associação direta desse combustível com os rejeitos, decidimos comentar alguns aspectos relacionados à sua armazenagem.

Romanato (2005) indica que existem dois métodos de armazenagem de combustível nuclear queimado: por via úmida, em que é utilizada a água como meio de refrigeração, e por via seca, na qual a refrigeração é feita por circulação de ar.

A Figura 2.1 apresenta, de uma forma sintética, as recomendações de armazenagem de rejeitos radioativos, preparadas pela Federação das Companhias de Energia Elétrica do Japão. 
Barriers for Radioactive Materials

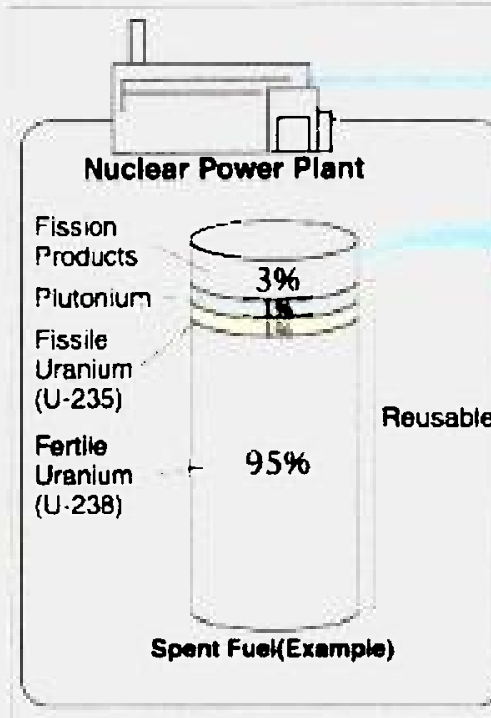

Disposal

Storage
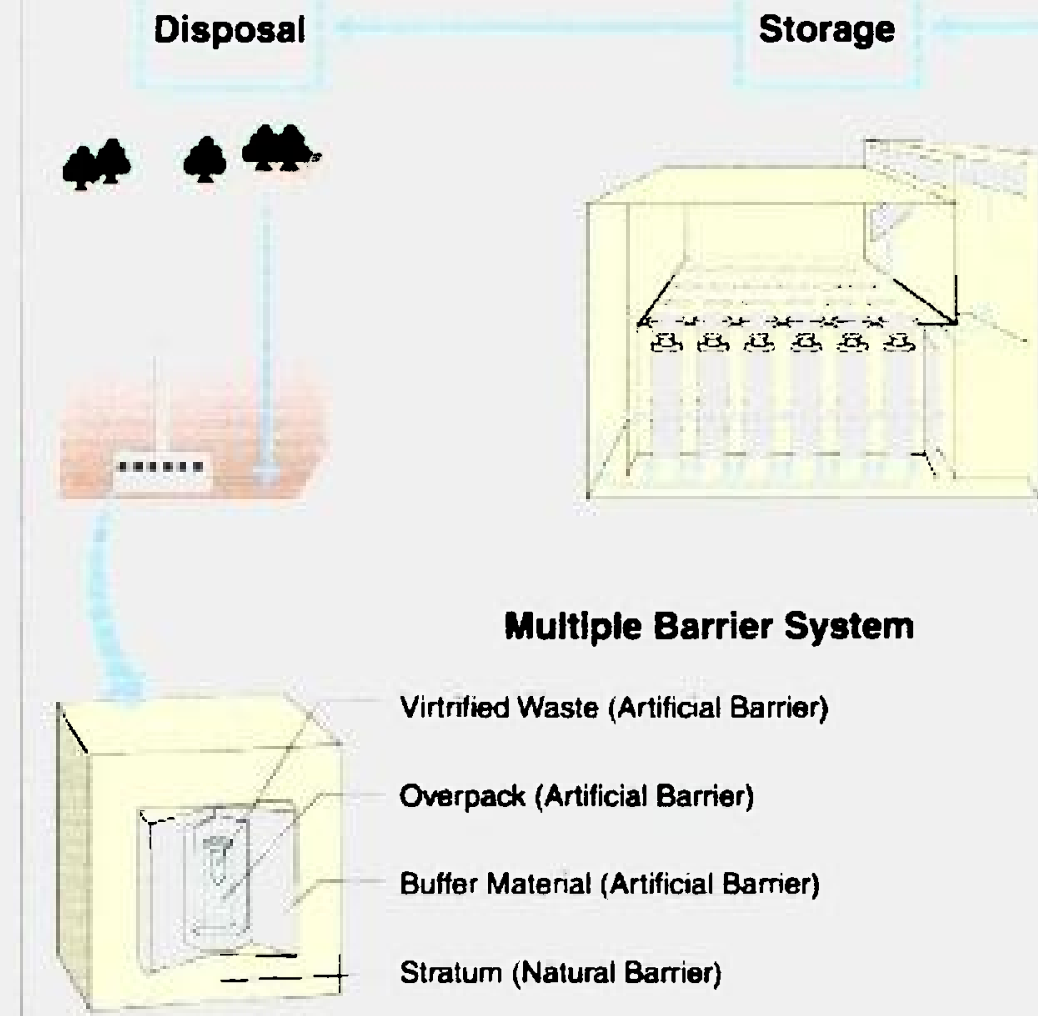

Vitutied Waste

High-level Hadioaclive

Waste

(t)ission

Products)

Multiple Barrier System

Virtrified Waste (Artifical Barrier)

Overpack (Artificial Barrier)

Buffer Material (Artificial Barrier)

Stratum (Natural Barrier)

Figura 2.1 Barreiras para o material radioativo

Fonte: http://www.fepc.or.jp/english/nuclear/cycle/disposal.html Acesso em 6.5.2007

Romanato (2005) apresenta uma curva, reproduzida na Figura 2.2, que mostra o calor gerado por diferentes elementos radioativos contidos no combustível 
nuclear queimado retirado de um reator, em função do tempo. Na Figura 2.3, reproduzida do mesmo autor, é apresentada uma curva que mostra a radioatividade gerada pelos produtos de fissão contidos no combustível nuclear queimado.

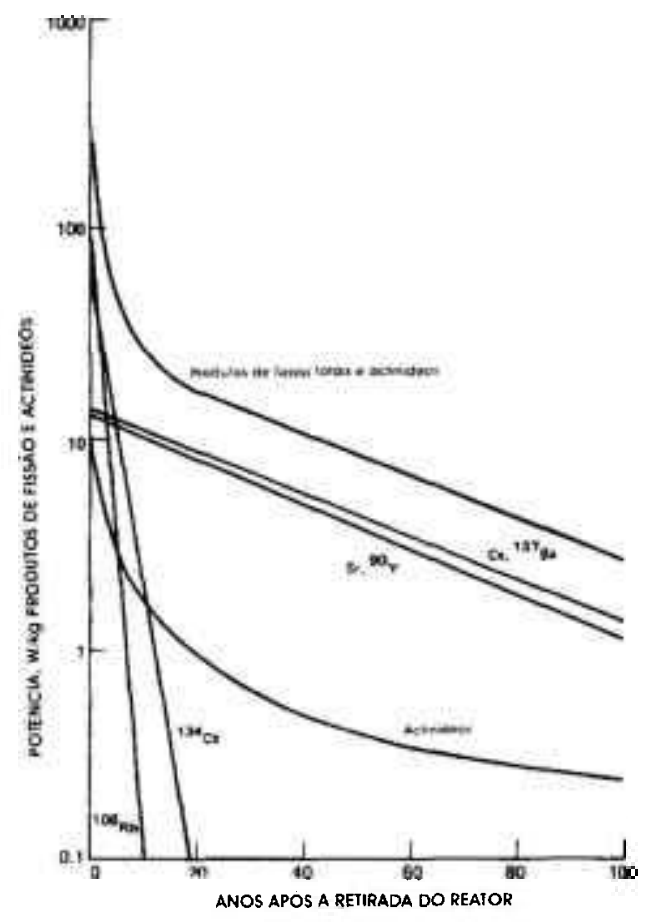

Figura 2.2 Calor gerado por diferentes elementos radioativos em combustivel nuclear queimado.Fonte: National Academy of Science, apud Romanato, 2005

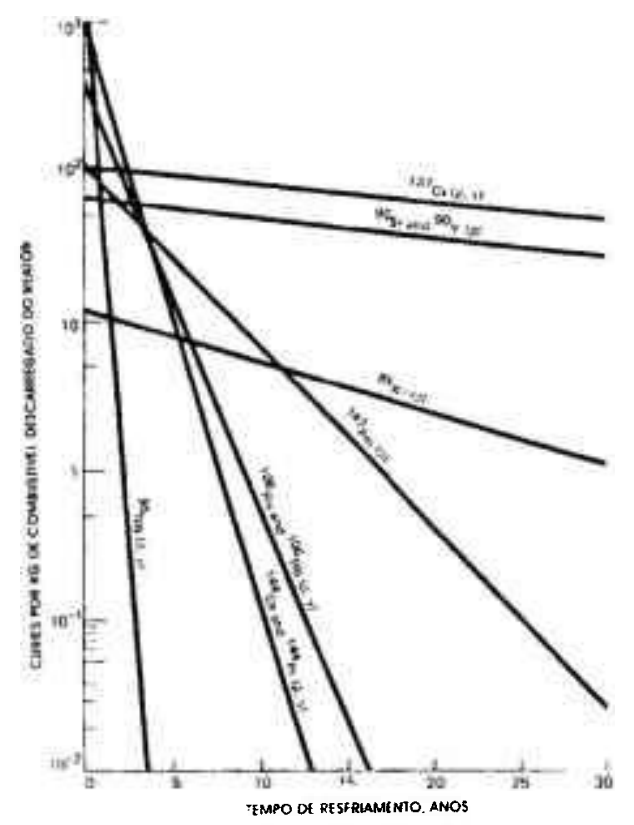

Figura 2.3-Radioatividade produzida pelos produtos de fissão de um CNQ, em função do tempo. Fonte: National Academy of Science, apud Romanato, 2005 
Observamos que, em muitos países, o uso intensivo da energia nuclear ocorreu antes de serem tomadas providências referentes à disposição correta dos rejeitos. Aumentando a quantidade de rejeitos, sem uma destinação mais apropriada, estes passaram a serem armazenados na superfície, em locais de acesso controlado, solução considerada provisória.

Grande parte do combustivel queimado, após a sua remoção do reator nuclear, fica armazenada em piscinas localizadas no mesmo prédio que o reator, usualmente por um periodo entre 3 e 5 anos. A água da piscina tem a função de refrigerar o combustível removendo o calor gerado pelas reações de decaimento radioativo e de prover blindagem biológica para os operadores.

Em alguns países, após esse período, o combustível queimado passa a ser armazenado a seco. Os elementos combustiveis são armazenados em cascos, que precisam ser muito duráveis, com resistência mecânica elevada (resistência aos esforços impostos e choque), além de resistência à corrosão e a outras formas de degradação, proporcionando blindagem à radiação e resfriamento do conteúdo (calor de decaimento). Em muitos casos, estes contêineres ficam guardados em estruturas de concreto, de forma a aumentar a segurança de armazenagem e prover uma blindagem adicional à radiação. Estas instalações devem ser construídas em local seguro, na superfície ou subsuperfície, em perímetro cercado, sendo vigiadas permanentemente.

Romanato (2005) recomenda que o material seja armazenado (ainda de forma provisória) por via seca, em poços ou silos, acondicionado em cascos especiais (Figura 2.4). 


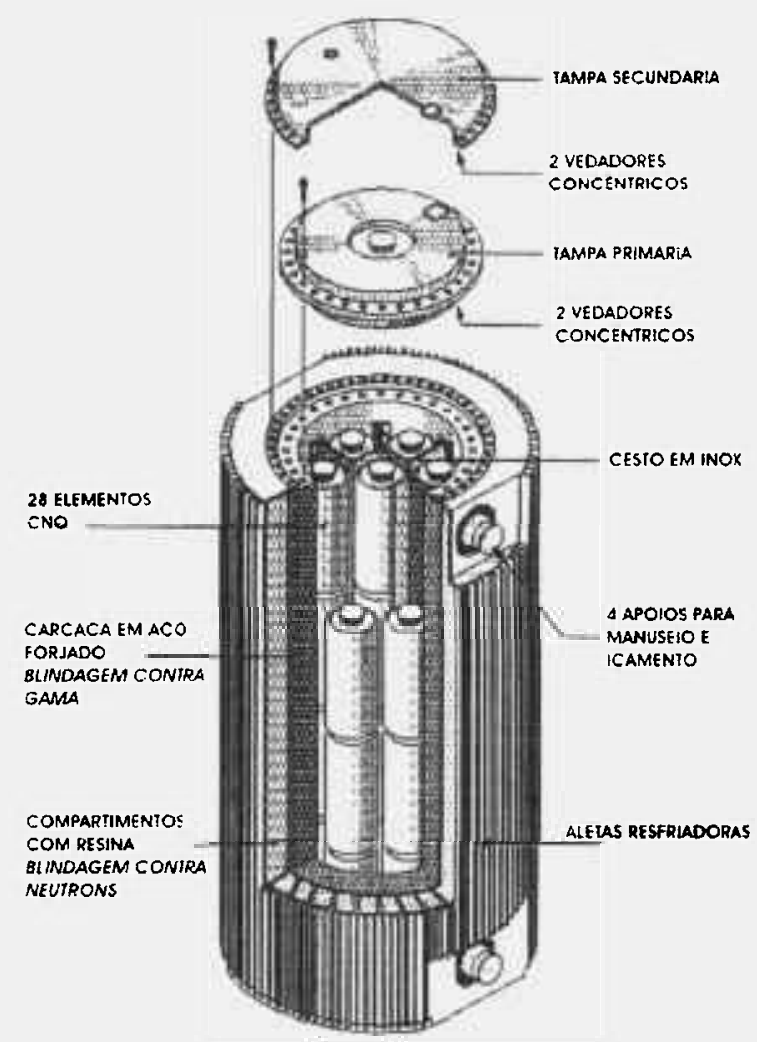

Figura 2.4 - Casco de aço com aletas para armazenagem de CNQ Fonte: http://www.fepc.or.jp apud Romanato, 2005

A Figura 2.5 mostra uma foto onde são observados contêineres de armazenamento de combustivel nuclear da Usina de Prairie Island, que possuem um revestimento de $23 \mathrm{~cm}$ de aço carbono. Cada contêiner pode receber até 16 toneladas de combustível queimado. (LONG, 2002, p.30).

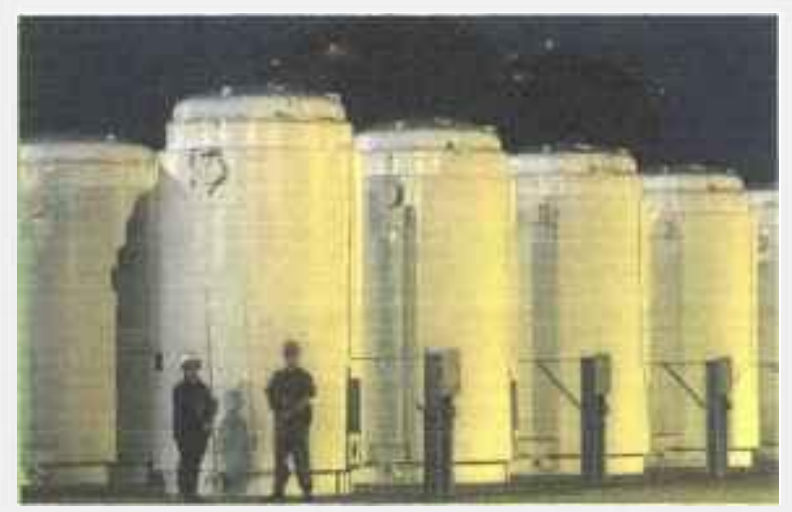

Figura 2.5 - Armazenamento de superfĩcie de combustivel nuclear queimado Fonte: Long, 2002

A Figura 2.6 mostra uma fotografia de uma instalação da empresa INVAP, na Argentina. 


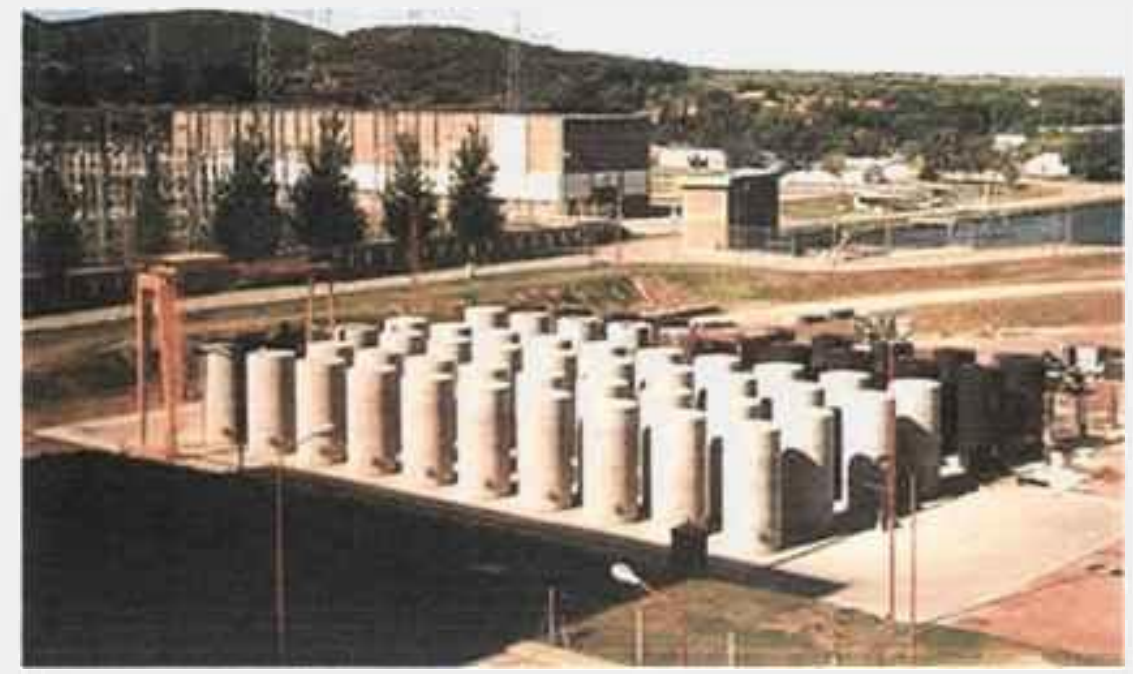

Figura 2.6 - Silos verticais de concreto armado para armazenagem de combustível nuclear queimado Fonte: http://www.invap.net/nuclear/asecq/intro-e.html. Acesso em 8.5.2007

Em alguns casos, as instalações de armazenagem são enterradas, poucos metros abaixo da superficie, de forma a aumentar a blindagem e a segurança. São instalados detectores de radiação e de vazamentos de contaminantes que possam, eventualmente, escapar dos contêineres.

Na figura 2.7 é apresentada a armazenagem de elementos combustíveis queimados em poços, próximo à superfície. É previsto o insuflamento de ar entre os cilindros ou resfriamento por convecção natural. Estas instalações são localizadas em Hanford (USA, foto à esquerda) e em Cascad (França, foto à direita).

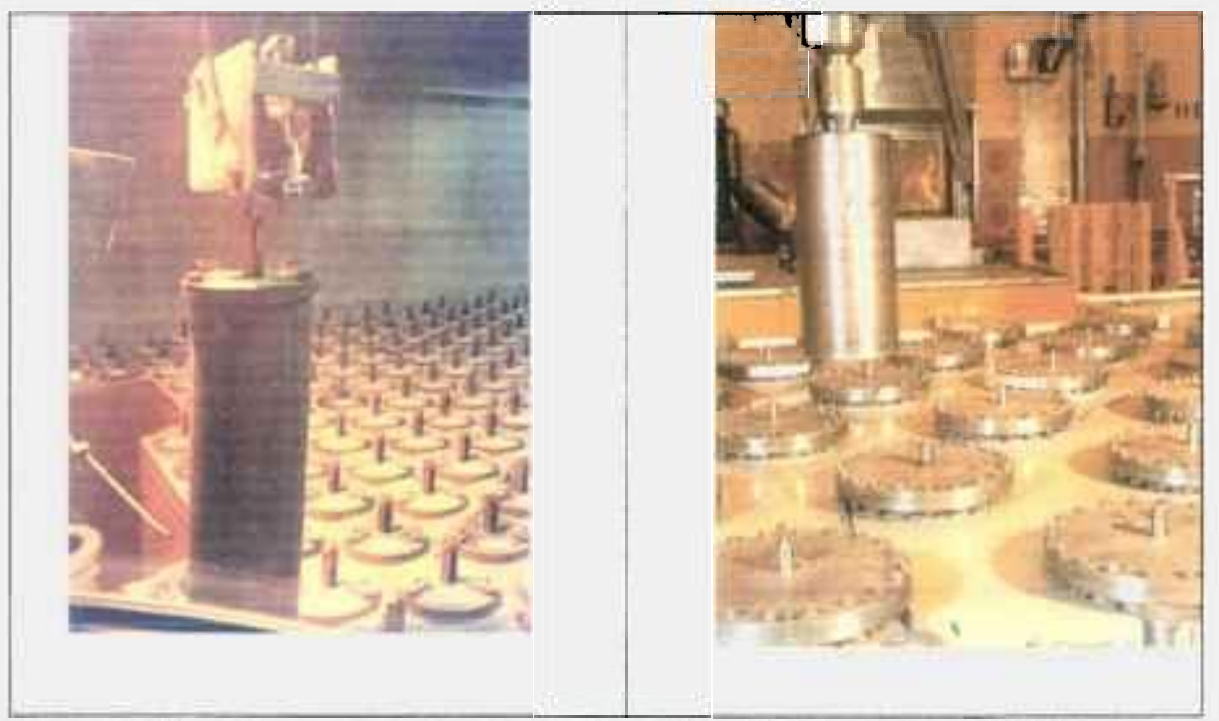

Figura 2.7 - Armazenagem de rejeitos radioativos de alta atividade em poços (em Hanford, USA - foto à esquerda) e Cascad, na França - foto à direita) Fontes: (www.qmetrics.com) e (www.cea.fr) (Acesso em 13.5.2007) 
Alguns rejeitos líquidos são armazenados em tanques subterrâneos, aguardando procedimento de vitrificação, como é o caso dos residuos do processamento de plutônio, em Hanford, Washington.

Caso o país disponha de instalações de reprocessamento (ou esse serviço seja contratado em países que disponham da tecnologia), o combustível pode ser enviado para essas instalações para ser submetido a processos físico-químicos, de forma a recuperar o plutônio e o urânio, que serão utilizados em um novo combustível (óxido misto), sendo separados os demais componentes (actinídeos menores e produtos de fissão), que devem ser armazenados e gerenciados em repositórios permanentes, por milhares de anos.

Um fato que preocupa muitas pessoas é a prática da armazenagem temporária nas piscinas se tornar uma armazenagem por tempo indeterminado, pela falta de outras instalações adequadas para a armazenagem definitiva. Essa solução não é uma prática sustentável, em vista do volume finito das piscinas e a existência de um risco mais alto.

Atualmente, a melhor técnica para a disposição permanente de rejeitos radioativos de alta atividade é a sua armazenagem em depósitos a grande profundidade, chamada de disposição geológica ou de repositório permanente. Ela é a mais indicada para países que dispõem de quantidades elevadas de rejeitos. Considera-se que essa solução é aquela mais consistente com a sustentabilidade, protegendo as gerações atual e futura.

Além da colocação dos rejeitos em cascos especiais, a disposição geológica proporciona uma série de barreiras, além da barreira natural representada pela rocha do local. As várias barreiras impedem a contaminação do ser humano ou outros seres vivos. A primeira barreira é a matriz onde está imobilizado o rejeito (blocos de concreto ou de vidro), seguida de barreiras técnicas (sistemas passivos, como alarmes de radioatividade), a geosfera (rochas) e, por último a biosfera, somente em seguida, caso violadas todas as barreiras, haveria a possibilidade da radiação atingir o meio ambiente e o ser humano.

A disposição geológica ocorre em túneis abertos em vários tipos de materiais, tais como depósitos de sal (projeto da Suécia), ou rochas como magma endurecido, rochas vulcânicas, granito, gnaisse, basalto ou outras. A profundidade escolhida irá depender da formação rochosa e da sua capacidade de isolamento. Por 
exemplo, em rochas duras recomenda-se uma profundidade entre 500 e $1000 \mathrm{~m}$, com poucas zonas de fraturas ou falhas (IAEA, 2003).

A disposição geológica visa um armazenamento definitivo, permanente, previsto para durar por muitas gerações, não havendo interesse em se recuperar futuramente o material, por exemplo, para reprocessamento. Essa instalação, após ser totalmente ocupada pelas embalagens de rejeitos, poderá ter seu acesso fechado na superfície. Nesse caso, será muito reduzida a atividade posterior de gerenciamento.

Atualmente, existe uma planta piloto de isolamento de rejeitos nos Estados Unidos (Waste Isolation Pilot Plant - WIPP), construida para armazenar com segurança rejeitos radioativos transurânicos. Ela fica localizada no deserto de Chihuahuan, próximo a Carlsbad, Estado do Novo México, estando operacional desde março de 1999. (Fonte: http://www.wipp.energy.gov, acesso em 5.12.2007). Outra instalação de maior porte, em construção é a de Yucca Mountain, também nos Estados Unidos, cuja entrada sul é mostrada na Figura 2.8 (LONG, 2002, p.30).

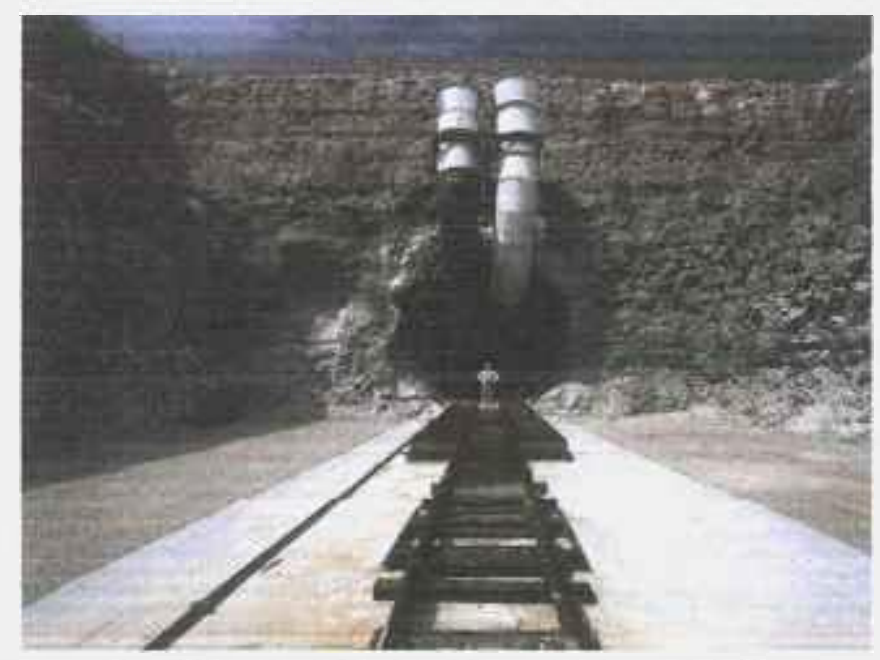

Figura 2.8 Entrada Sul do depósito de Yucca Mountain, USA

Fonte: Revista National Geographic Brasil, julho 2002, p.58

Com relação à estocagem dos rejeitos de atividade baixa, o depósito deverá cumprir as Norma NE - 6.06 - Seleção e Escolha de Locais para Depósitos de Rejeitos Radioativos (CNEN, 1989) e NN - 6.09 - Critérios de Aceitação para Deposição de Rejeitos Radioativos de Baixo e Médio Níveis de Radiação (CNEN, 2002). Todas as normas internacionais sobre o assunto mostram cuidados com os requisitos para a localização, projeto e operação dos depósitos de rejeitos, incluindo afastamentos em 
relação a vizinhanças. Segundo a Norma da U.S. Nuclear Regulatory Commission 10 CFR 61.7, o controle institucional de acesso é requerido por mais de 100 anos (NRC, 2007, item 61.7, parágrafo 4). Segundo essa mesma norma, para a escolha do local de disposição de rejeitos próximos à superfície, deverão ser consideradas as características do local em termos de um futuro indefinido, com a avaliação considerando pelo menos um horizonte de 500 anos (U.S.NRC, 2007).

A Figura 2.9 apresenta uma fotografia de um depósito deste tipo, localizado na Espanha, no Centro de Armazenamento de El Cabril, província de Córdoba. Outros desenhos esquemáticos mostram sua forma de armazenamento.

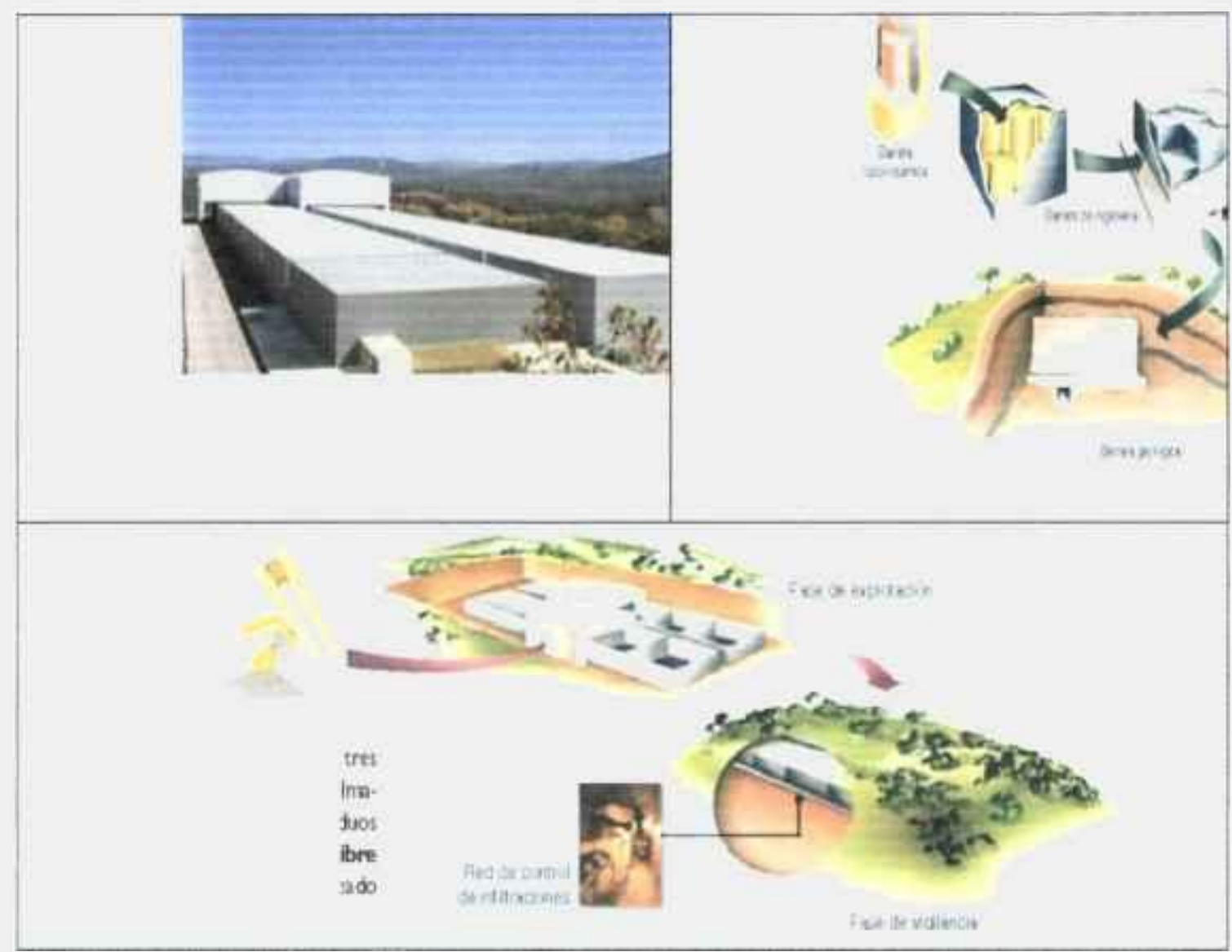

Figura 2.9 - Centro de Armazenamento de Rejeitos de Média e Baixa Atividade de El Cabril, Espanha.

Fonte: http://www.enresa.es/, acesso em 6.5.2007

Os ingleses possuem um repositório para rejeitos radioativos de baixa atividade em Drigg, West Cumbria, cerca de $7 \mathrm{~km}$ a sudeste de Sellafield, que opera desde 1959. Os rejeitos são armazenados em depósitos subterrâneos construídos em concreto. Quando possível, os rejeitos são compactados e colocados em contêineres, 
antes da armazenagem subterrânea. A Figura 2.10 apresenta fotos de armazenagens desse tipo, na Inglaterra e na França.

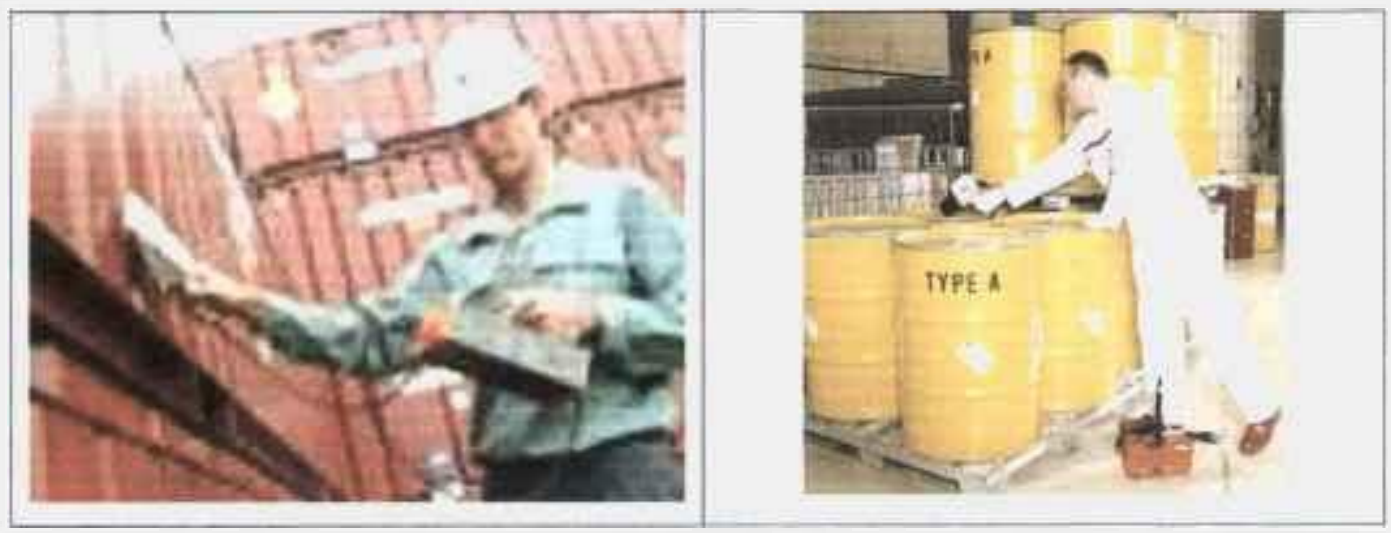

Figura 2.10 - Contêineres de armazenagem de rejeitos de baixa atividade em Drigg (UK) (à esquerda) e em tambores na França (à direita)

Fontes: http://www.britishnucleargroup.com e www.cea.fr (acessos em 6.5.2007)

$\mathrm{O}$ descomissionamento de reatores de potência e de pesquisa, bem como reatores de submarinos, constitui-se em uma operação delicada, sendo necessário um controle rigoroso das atividades, visando à proteção dos trabalhadores, do público e do meio ambiente. São gerados elevados volumes de rejeitos, principalmente de média atividade. Os materiais estruturais (aço e concreto) são considerados como sendo de baixa atividade. (IAEA, 2004a).

No Brasil, os rejeitos de atividades média ou baixa, resultantes do ciclo de produção do combustivel nuclear, operação de centrais nucleares, hospitais e outras instalações, são armazenados nos depósitos intermediários em instalações da CNEN, como o Instituto de Pesquisas Energéticas e Nucleares (IPEN), o Centro de Desenvolvimento da Tecnologia Nuclear (CDTN) e o Instituto de Engenharia Nuclear (IEN).

\subsection{Novas tecnologias para reduzir a quantidade de rejeitos a estocar}

Recentemente, vêm sendo estudadas duas técnicas para reduzir a quantidade dos elementos transurânicos, que consistem na transmutação e no reprocessamento.

Segundo Moreira e Abe (2006), a transmutação nuclear consiste no processo de um elemento transformar-se em outro, por meio de reações nucleares induzidas por partículas como nêutrons. Por meio da fissão nuclear e a captura de nêutrons, são obtidas 
as reações desejadas, submetendo determinados elementos a um campo intenso de nêutrons. Algumas das possiveis reações de transmutação, objeto de interesse, são:

Fissão:

nêutron $+{ }^{239} \mathrm{Pu}(24000$ anos $) \rightarrow{ }^{134} \mathrm{Cs}(2$ anos $)+{ }^{104} \mathrm{Ru}$ (estável) +2 nêutrons + Energia

Captura e Fissão:

nêutrons $+{ }^{240} \mathrm{Pu}(6600$ anos $) \rightarrow{ }^{241} \mathrm{Pu}(14$ anos $)+$ nêutron

nêutron $+{ }^{241} \mathrm{Pu}(14$ anos $) \rightarrow{ }^{134} \mathrm{Xe}$ (estável) $+{ }^{105} \mathrm{Rh}(35$ horas $)+$ nêutrons + Energia

Captura:

nêutron $+{ }^{99} \mathrm{Tc}\left(2.1 \times 10^{5}\right.$ anos $) \rightarrow{ }^{100} \mathrm{Tc}(15.8$ segundos $) \rightarrow{ }^{100} \mathrm{Ru}$ (estável)

Nota: os números entre parênteses representam as meias vidas dos vários isótopos.

Para reduzir a quantidade armazenada de elementos transurânicos, pode-se usar uma outra reação de transmutação, com um processo mais conhecido como "incineração". Ele pode ser realizado em reatores PWR (com baixa eficiência), em reatores rápidos (que apresentam um espectro de energia mais favorável para a transmutação dos transurânicos, denominados de reatores incineradores) ou em aceleradores de partículas de alta potência acoplados a reatores subcríticos e aceleradores de prótons de alta potência (Accelerator Driven Systems). Em uma reação de spallation, é possível transmutar grandes quantidades de elementos radioativos em elementos de vida curta ou, até mesmo, estáveis. As pesquisas atuais visam principalmente o neptúnio, o amerício e o cúrio, presentes nos combustíveis queimados de reatores. (CEA, 2007b)

O reprocessamento do combustível queimado é outra forma de evitar a necessidade de armazenagem desse material altamente radioativo, além de permitir um melhor aproveitamento energético. Com essa técnica, utilizada em instalações especiais, com blindagens e outros recursos de tratamento, remove-se o plutônio, que é misturado a urânio enriquecido, fabricando-se um novo combustível denominado óxido misto (MOX - mixed oxyde) ou $\mathrm{UO}_{2}-\mathrm{PuO}_{2}$, que é usado em reatores para a produção de energia elétrica. Essa tecnologia já vem sendo empregada em países como a França e o Japão. É necessário um cuidado elevado com os licores resultantes dos processos. Os materiais sólidos devem ser removidos, tratados e submetidos a um processo de vitrificação, para posterior disposição em repositórios permanentes. 


\section{IMPLANTAÇÃO DE UM SISTEMA DE GESTÃO AMBIENTAL}

Este capítulo, baseado em Moura (2004), visa definir as bases gerais para a implementação de um Sistema de Gestão Ambiental em uma organização. Apesar de conter requisitos da Norma ABNT NBR ISO 14.001 (ABNT, 2004) e sugestões de ações a tomar, aplicáveis a qualquer tipo e porte de organizações, particulariza a sua aplicação para uma instalação de armazenagem de rejeitos radioativos de atividades média e baixa. No capítulo 4, as sugestões se tornam mais específicas para esse tipo de instalação.

\subsection{Vantagens em melhorar o desempenho ambiental}

Qualquer organização deve, antes de tudo, atender às necessidades de seus clientes. Este deve ser sempre seu objetivo principal, sendo vital para que ela possa sobreviver. Os "clientes" de organizações como um Centro de Pesquisas ou uma instalação de armazenagem de rejeitos radioativos serão a Sociedade, os órgãos de controle ambiental (representando a Sociedade), vizinhos e outros interessados no desempenho ambiental daquela organização. E a sociedade, hoje, principalmente influenciada pela mídia (jornais, televisão, revistas), tem aumentado a sua participação nas decisões a respeito de empreendimentos nucleares, principalmente em razão do risco percebido. Nesse contexto, verifica-se que a proteção ambiental passou a ser uma necessidade das pessoas, e que, para sobreviver, as organizações estão se estruturando para atender melhor este aspecto, criando mecanismos especificos para atuar, interna $\mathrm{e}$ externamente, em melhorias de desempenho ambiental.

As razões que existem para a melhoria dos processos internos relacionados à estocagem de rejeitos radioativos são:

a) Maior satisfação das pessoas que interagem com a organização, como por exemplo, os representantes de órgãos ambientais, vizinhos, funcionários;

b) Melhoria da imagem da organização, junto aos clientes, órgãos governamentais, comunidade, vizinhos, ONGs e mídia. É muito importante que a organização tenha uma imagem positiva junto a essas entidades, essencial à sua aceitação pela sociedade. Sem dúvida, um bom desempenho ambiental auxilia no reforço da reputação e, ao contrário, problemas e acidentes ambientais irão colaborar negativamente 
para o conceito da organização;

c) Redução de custos, pela eliminação de desperdícios, obtida com uma análise cuidadosa dos processos, uso mais racional dos recursos, tais como água, energia e matérias primas, além de redução da produção de resíduos e poluição que, no fundo, são perdas de materiais e de energia. O tempo, e a quantidade de mão-de-obra utilizada na remediação de problemas ambientais, também têm um custo, principalmente na área nuclear, onde esses problemas são classificados como gravíssimos. Outro ponto de redução de custos em instalações bem projetadas e operadas sob o aspecto ambiental, são as reduções de prêmios de seguros e gastos menores com indenizações resultantes de acidentes;

d) Melhoria do desempenho da organização, com aumento da produtividade. A organização que tem um bom desempenho tem mais facilidades na obtenção de licenças de instalação e operação junto aos órgãos governamentais, obtendo com maior facilidade a aprovação dos seus Estudos de Impacto Ambiental - Relatório de Impactos Sobre o Meio Ambiente (EIA-RIMA). As melhorias de desempenho ambiental são conseguidas por meio de um processo estruturado de ações gerenciais, apoiadas por um forte programa de treinamento. Nesse programa, deverão ser aprendidas técnicas de administração e conceitos de qualidade, que fatalmente serão aplicados por todos em outras atividades de sua vida profissional, não somente em relação às questões ambientais, resultando em melhorias globais de desempenho da organização. Além disso, é estimulado um trabalho em equipe que serve de modelo para outros trabalhos na organização, refletindo-se em uma melhor integração das pessoas, com grandes ganhos de produtividade e eficácia;

e) Redução dos riscos, pois a organização que tiver sido bem estruturada para tratar dos seus aspectos ambientais apresenta um menor risco de ter que arcar com multas (cada vez mais pesadas), ações legais por descumprimento da legislação, menor probabilidade de acidentes ambientais sérios, menor passivo ambiental, melhor identificação das vulnerabilidades (ao serem realizadas as análises de confiabilidade dos processos, visando aspectos ambientais, ficam bem conhecidos os pontos fracos sobre os quais é interessante atuar), menor risco para os administradores (ao serem realizadas as auditorias ambientais aparecerão aspectos de risco que não eram visíveis e, na ocorrência de acidentes, os administradores poderiam ser criminalmente responsabilizados, embora desconhecessem os pontos fracos). Se a organização investir em ações preventivas a problemas ambientais, seguramente ela reduzirá seus riscos; 
f) Maior facilidade na obtenção de certificação. Uma organização que tenha uma administração preocupada com a variável ambiental e um sistema gerencial estruturado para administrar o seu bom desempenho está, em princípio, bastante mais próxima de obter uma certificação, que assegura que ela cumpre uma norma ambiental, por exemplo, a norma ABNT NBR ISO 14001 (ABNT, 2004). Sugerimos que as organizações, mesmo que não visem certificação em uma determinada época, tenham a preocupação de procurar melhorar seu desempenho ambiental, visando um interesse futuro em relação a este aspecto. Com a adoção de procedimentos e padrões de desempenho, monitoramento de efluentes e resíduos, entre outras ações, o processo de certificação ficará muito mais rápido, limitando-se à ajustagem de pontos específicos, realização de auditorias internas para confirmar o atendimento aos requisitos das normas e solicitaçăo de auditoria pela entidade certificadora.

\subsection{Sumário da implantação de um sistema de gerenciamento ambiental}

A implantação de práticas ambientais corretas em uma organização, ou em parte dela, é sempre interessante e necessária, trazendo inúmeros benefícios. Dependendo do seu porte, passa a ser necessário existir um setor específico voltado a essas atividades e que cuide dos aspectos ambientais dos produtos, serviços e processos industriais, eventualmente implantando-se um sistema de gerenciamento ambiental.

A decisão sobre a necessidade, ou não, de implantação de um sistema de gestão ambiental deve ser feita analisando-se, conforme foi apresentado anteriormente, se isto vai atender ou não a uma "necessidade dos seus clientes" e avaliando-se de que forma esse sistema irá colaborar para auxiliar no cumprimento da legislação ambiental. A implantação de um SGA é uma das melhores formas para conseguir obter melhorias de desempenho ambiental em uma organização e, nesse trabalho, serão cumpridos, basicamente, 3 grandes conjuntos de atividades:

a) Análise da situação atual da organização. Verificar "onde estamos" no momento, no tocante ao desempenho atual, quanto aos seus processos, produtos e serviços. Verificar os requisitos da legislação. É a fase de diagnóstico do problema, sendo identificados os impactos ambientais principais que resultam das atividades da organização;

b) Estabelecimento de Metas. Estudar as possibilidades fisicas, recursos materiais e humanos necessários e, a partir de diretrizes vindas da Política Ambiental, definir "onde queremos chegar" em termos de melhorias, em um certo período de tempo; 
c) Estabelecimento de Métodos. A palavra método tem uma origem grega que significa "caminho para se alcançar a meta". Ou seja, o estabelecimento de métodos, ou de um determinado modo de trabalho, vai definir "como chegar" aos resultados pretendidos, para que sejam atingidas as metas.

A implementação e operação de um SGA consiste, na realidade, na aplicação de conceitos e técnicas de administração, particularizados para os assuntos de meio ambiente. Existem, dessa forma, várias técnicas possíveis e que levam a resultados semelhantes, sendo interessante utilizar as ferramentas empregadas em Qualidade Total, associadas a conceitos e requisitos estabelecidos na norma internacional ISO 14001.

Uma reflexão sobre o assunto indica que a obtenção de QUALIDADE AMBIENTAL é resultado de uma série de fatores que, em conjunto, irão compor um sistema (conjunto interligado e harmonioso desses fatores):

a) resultado de existir uma POLÍTICA AMBIENTAL, originária da Alta Direção, que define uma linha de conduta para toda a organização quanto às questões ligadas ao meio ambiente;

b) resultado de se elaborar um PLANEJAMENTO ADEQUADO, definido a partir de um diagnóstico da situação ambiental da organização, com a identificação de impactos, atribuição de prioridades em sua solução, estabelecimento de metas e preparação de um Plano de Ação e atribuição de recursos para a consecução desse plano após uma análise econômico-financeira;

c) resultado da existência de um nível adequado de EDUCAÇÃO AMBIENTAL, aqui visto em seu sentido mais amplo, com formação das pessoas nos conceitos mais importantes de Ciência Ambiental, obtenção de um padrão elevado de motivação para que se consiga bons resultados e formação das pessoas nas técnicas necessárias para gerenciar o processo e realizar as atividades profissionais relacionadas ao desempenho ambiental. $O$ processo de educação deverá estimular o desenvolvimento de valores pessoais e institucionais e melhores padrões de comportamento;

d) resultado de um MODO DE TRABALHO, consequêencia de uma boa estruturação de procedimentos e instruções de trabalho, de forma que todos os participantes trabalhem de uma forma correta e com maior eficiência. Deverá ser assegurada a existência de um processo estruturado e transparente de tomada de decisões em todos os níveis da organização; 
e) resultado de um TRABALHO CONTÍNUO, sem se deixar abater pelas adversidades e dificuldades naturais, cujos resultados serão fruto principalmente de muita persistência e dedicação na busca de melhorias contínuas;

f) resultado de um processo bem estruturado de VERIFICAÇÕES e acompanhamento de todos os passos programados, com monitoramento constante das variáveis importantes dos processos industriais (evitando emissões de poluentes e descarte de resíduos fora dos níveis normais estabelecidos) e de um processo de auditorias sistemáticas e organizadas para assegurar o desempenho adequado do sistema;

g) resultado do estabelecimento de MECANISMOS EFICIENTES para identificar, em conjunto com os auditores, problemas e desvios de procedimento permitindo que sejam tomadas medidas corretivas ou, preferencialmente, ações preventivas, de forma a evitar tais problemas (que normalmente acarretam custos mais elevados de remediação).

Uma ferramenta gerencial importante, e que poderá resumir toda a implantação do processo do SGA é o ciclo PDCA, também conhecido como Ciclo de Shewhart-Deming, composto por quatro grandes passos: Plan (Planejar); Do (Realizar); Check (Verificar); e Act (Atuar para corrigir). Esse ciclo deve ser precedido por uma atividade de "Estabelecimento da Política Ambiental" da organização.

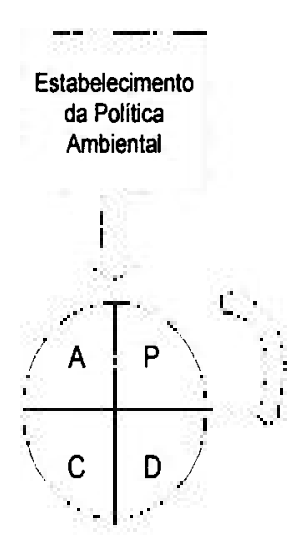

Figura 3.1 - Ciclo PDCA

Detalhando melhor as atividades de cada uma dessas etapas, para aplicar o PDCA a um Sistema de Gestão Ambiental, tem-se: 


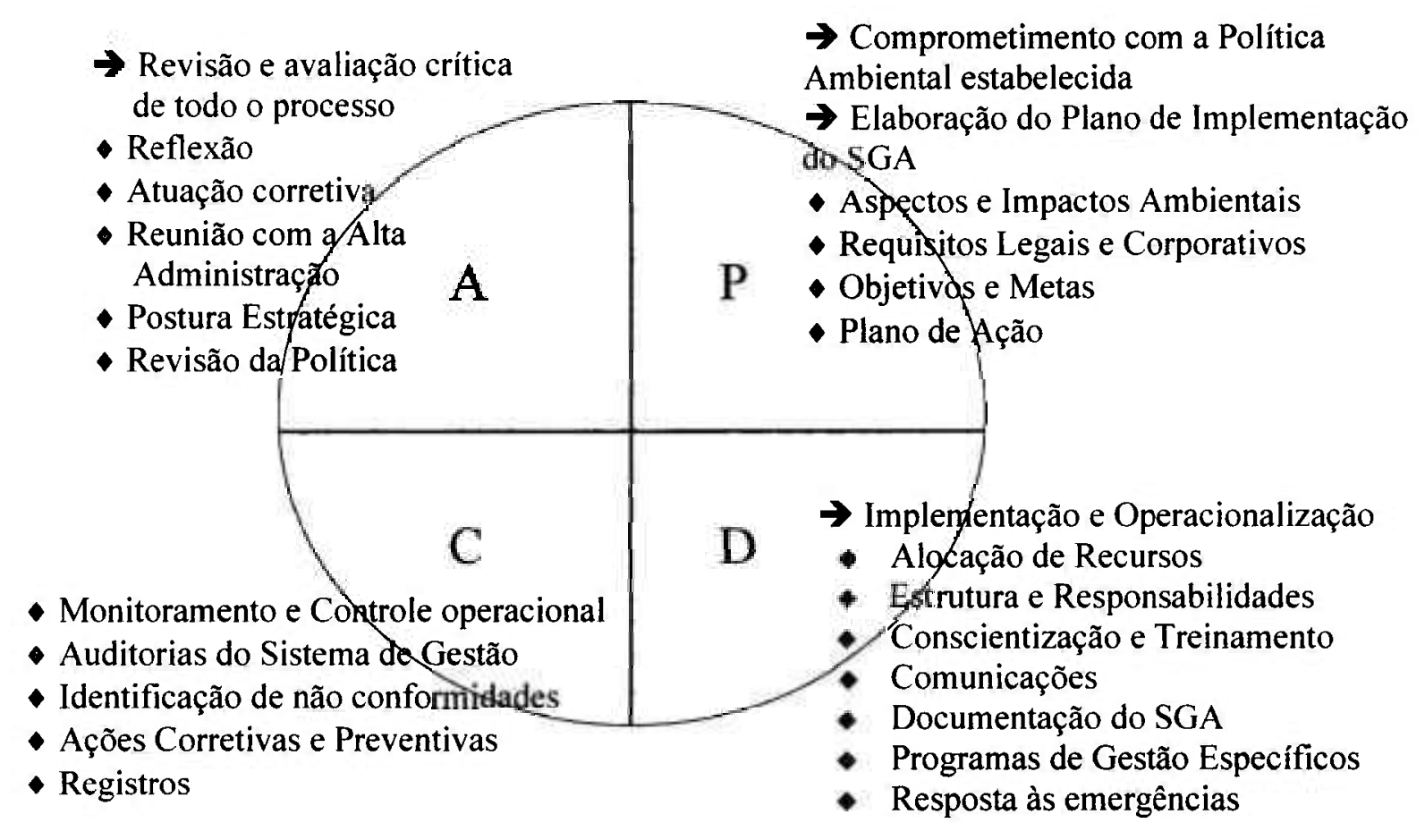

Figura 3.2 - PDCA aplicado a um Sistema de Gestão Ambiental

\subsection{As etapas de planejamento}

Antes de começar as ações que visam melhorar o desempenho das organizações que tratam dos rejeitos radioativos, é necessário que seja realizado um intenso trabalho de planejamento, a fim de que sejam identificados os problemas e seja preparada toda a infra-estrutura para a boa solução desses problemas, sobretudo em termos de recursos materiais, humanos e financeiros. Os gerentes de nível mais elevado deverão estabelecer os planos, objetivos e metas para definir as estratégias para a organização, consideradas de modo integrado a outras estratégias gerenciais, evitando-se conflitos.

\subsubsection{Política Ambiental}

Uma "política", em uma organização, é o conjunto de intençð̃es de sua alta administração sobre um determinado assunto, das quais irão decorrer uma série de medidas e procedimentos que orientam as condutas gerenciais. Ela determina um senso geral de orientação, fixando os princípios gerais a serem seguidos por todos. Reflete um conjunto de princípios que, nas pequenas organizações, normalmente não são escritos, mas constituem um código de conduta conhecido e respeitado. Na medida em que a 
organização cresce de tamanho e complexidade, as políticas passam a ser definidas com mais formalidade, forçando os gerentes a atuarem com mais uniformidade naquele assunto, segundo as diretrizes e vontades oriundas dos níveis hierárquicos mais elevados.

Uma organização que queira estabelecer um sistema de monitoramento do seu desempenho ambiental ou, mais apropriadamente, um Sistema de Gestão Ambiental, deve estabelecer sua "Política Ambiental". A alta administração usualmente é constituída de um indivíduo ou de um grupo de indivíduos que orientam e controlam uma organização em seu mais alto nível (ABNT, 2004), cabendo a ela estabelecer a Política, que deve ser feita por escrito, pelas seguintes vantagens:

a) ela permite que todas as pessoas da organização conheçam as intenções (o comprometimento) da alta administração, sem a distorção que poderia ocorrer em comunicados verbais feitos por meio dos vários niveis hierárquicos de chefia;

b) ela permite que as "partes interessadas", ou seja, o público externo, clientes, fornecedores, órgãos ambientais, entre outros, conheçam essas intenções e a importância na fixação de objetivos e prioridades;

c) faz-se necessário que os dirigentes reflitam sobre o assunto antes de formular uma definição, conduzindo a um comprometimento maior e mais realista de cumprimento de metas;

d) sem a existência de políticas escritas emanadas dos níveis mais altos, corre-se o risco de que os níveis mais baixos formulem políticas informais, ocupando o espaço deixado vago, formalizando práticas que poderiam, em alguns casos, estar em desacordo com as intenções da alta administração;

e) ela permite que as auditorias tenham um ponto de partida em relação aos pontos a verificar.

Conforme definido na Norma ABNT NBR ISO 14001 (ABNT, 2004), "a alta administração deve definir a politica ambiental da organização e assegurar que, dentro do escopo definido de seu sistema de gestão ambiental, a política:

a) seja apropriada à natureza, escala e impactos ambientais de suas atividades, produtos ou serviços;

b) inclua um comprometimento com a melhoria contínua e com a prevenção de poluição;

c) inclua um comprometimento em atender aos requisitos legais aplicáveis e outros requisitos subscritos pela organização que se relacionem a seus aspectos ambientais; 
d) forneça uma estrutura para o estabelecimento e análise dos objetivos e metas ambientais;

e) seja documentada, implementada e mantida;

f) seja comunicada a todos que trabalhem na organização ou que atuem em seu nome;

g) esteja disponivel para o público".

Além da importância do estabelecimento de uma política ambiental, os outros pontos a serem comentados são:

a) Política adequada à natureza, escala e impactos ambientais das atividades, produtos e serviços.

$\mathrm{Na}$ preparação da política de uma organização devem ser evitados textos excessivamente genéricos, bem como a inadequação das intenções à realidade da organização. Deve ser buscada uma grande coerência das ações com o tipo de atividade realizada.

Quando se diz "apropriada à natureza", devemos considerar o tipo de atividade, produto ou serviço; "adequada à escala", implica em considerarmos o porte da organização, a amplitude geográfica da empresa e o reconhecimento e grau de importância dos impactos em regiões vizinhas.

\section{b) Melhoria Contínua}

Em concordância com a política ambiental, trata-se da melhoria do desempenho ambiental, ano a ano, como resultado de um esforço continuado. Ou seja, haveria uma postura de não se aceitar que a organização dê um salto de melhoria e se acomode. Esta melhoria será conseguida por meio de medidas tais como:

- utilização de tecnologias mais limpas nos processos envolvidos;

- a aplicação de medidas com o objetivo de reduzir os efeitos adversos ao meio ambiente, correspondendo à aplicação viável da melhor tecnologia, sem acarretar custos excessivos.

\section{c) Cumprimento da legislação e regulamentos}

A política ambiental não pode nunca apresentar conflitos com a legislação e regulamentos de órgãos ambientais do país em que a organização estiver instalada. Ao se comprometer com o cumprimento dos requisitos legais, a organização reforça o 
compromisso em cumprir todos os limites de emissões estabelecidos pelas autoridades competentes para aquele país, estado ou município. Dessa forma, fica proporcionada ao auditor uma base sólida, quando ele constatar um requisito não atendido, abrindo-se uma não conformidade por desrespeito à Política, já que a organização declarou que cumpriria esses requisitos. $O$ atendimento à legislação pode estar sendo realizado como resultado de um acordo com a autoridade competente, normalmente o órgão ambiental, situação em que a organização eventualmente não esteja naquele instante totalmente cumpridora da lei, mas esteja em processo de adequação, por meio de um Termo de Ajustamento de Conduta (TAC).

\section{d) Cultura de segurança}

A Política deverá dar um passo inicial visando desenvolver uma cultura de segurança na organização e estabelecer mecanismos para reforçá-la. Essa cultura terá o propósito de aumentar a conscientização dos trabalhadores quanto à necessidade de realização de trabalhos mais seguros, evitando-se acidentes e a contaminação do meio ambiente.

\section{e) Revisão dos objetivos}

A Política deverá ser revista com uma certa periodicidade, em função dos resultados alcançados pela organização, bem como sua adaptação às mudanças impostas pelos governos e a novos objetivos impostos. A Política deve apresentar a estrutura geral do sistema a ser implantado para o estabelecimento dos objetivos e metas ambientais da organização, bem como o processo periódico de revisão desses objetivos e metas.

\section{f) Documentação e comunicação}

Conforme aspecto já comentado, a política deve ser registrada por escrito e comunicada internamente na organização e às "partes interessadas", que são, segundo a norma (ABNT, 2004), "indivíduos ou grupos interessados ou afetados pelo desempenho ambiental de uma organização". Inclui aqueles que exercem controle legal sobre a questão ambiental da organização, residentes locais, a força de trabalho, seguradores, clientes e consumidores, grupos de interesse ambiental e o público em geral. Há a necessidade de que os gerentes comuniquem a todos os trabalhadores essa Política e que ela seja perfeitamente compreendida e seguida. 


\section{g) Disponibilidade para o público externo}

Conforme exigido pela norma (ABNT, 2004), a política ambiental deve ser publicada de forma a ser acessível ao público (jornais, internet, folhetos distribuídos a visitantes ou outros meios), sendo também divulgada à comunidade interna e vizinha à empresa (convite para visitas e reuniões de divulgação). A organização deverá identificar as necessidades, requisitos e expectativas das "partes interessadas" (stakeholders), para verificar continuamente se essas demandas são atendidas e como melhorar a satisfação desses interessados.

\section{h) Integração com outras áreas da organização}

A política tem que estar coerente com as diretrizes estabelecidas para as outras áreas da organização, para evitar conflitos. $O$ processo fica muito mais eficiente quando se observa que, em todas as decisões estratégicas, esteja sendo considerada a variável ambiental, sendo analisadas as repercussões dessas decisões.

A política é uma declaração de intenções da alta direção, sendo a base para o estabelecimento de objetivos e metas ambientais da empresa. Ela é a "força motriz para a implementação e aprimoramento do sistema de gestão ambiental de uma organização, permitindo que seu desempenho ambiental seja mantido e potencialmente aperfeiçoado" (ABNT, 2004).

Assim, a existência de uma Política Ambiental, além de ser requerida pela Norma ISO 14001, é um dos fatores mais importantes na obtenção de melhoria de desempenho.

A Política Ambiental deve ser escrita em linguagem fácil e acessível a todos os níveis da organização, não ser muito longa (já que há uma necessidade de que todos tenham conhecimento razoável de seu conteúdo, posto que será certamente avaliado pelos auditores em um processo de certificação) e cumprir os requisitos explicitamente colocados na norma.

A Política definirá as grandes metas no tocante ao desempenho ambiental pretendido pela alta administração. Essas metas, consideradas de alto nível (ou seja, de grande abrangência, mas ainda pouco detalhadas) orientarão o grupo de pessoas de toda a organização em implantar o sistema; todas as diretrizes subseqüentes terão que estar 
coerentes com as orientações vindas da Política. Mas, antes de emití-la em definitivo, deve-se realizar uma análise crítica para verificar se aquela política é realista em termos de possibilidades de sua concretização, principalmente no tocante aos recursos financeiros e humanos. Todas as grandes mudanças exigirão modernização de equipamentos e sistemas de produção, contratação ou treinamento de profissionais para capacitá-los aos novos métodos de trabalho e, ao emitir a política, a alta direção deverá prever a fonte de recursos necessários para atingir essas grandes metas que foram colocadas.

Uma Política Ambiental nunca será definitiva. Ela é preparada no início de um processo de implantação do SGA e, com o tempo, gradualmente serão implantadas muitas modificações na organização, decorrentes dessa própria política e das atividades de cumprimento do Plano de Ação. Assim, com o tempo, a Política ficará superada, necessitando de uma revisão e atualização, quando serão colocadas novas metas, para um período seguinte, por exemplo, em um novo ciclo PDCA.

A Política Ambiental deve ser assinada pelo responsável pela organização, em nível mais elevado, para reforçar a sua importância. Estes devem mostrar aos componentes da organização a necessidade de cumprimento dos requisitos do Sistema de Gestão (IAEA, 2004b).

Os gerentes de nível mais elevado deverão desenvolver o pessoal e os valores institucionais e padrões de comportamento para apoiar a implementação do Sistema de Gestão, e deverão atuar como modelos na adoção visível desses valores e padrões de comportamento. Ao mesmo tempo, eles deverão assegurar a existência de um processo para identificar e integrar os requisitos das partes interessadas (IAEA, 2004b).

As gerências, em todos os níveis, deverão demonstrar um comprometimento com o desenvolvimento, implementação e melhorias no Sistema de Gestão Ambiental.

Devem ser declaradas as exigências a serem cumpridas e, antes de formular a política, devem ser examinadas, de um modo preliminar, as implicações em termos de modificações a realizar, custos e metas, bem como uma idéia sobre como medir o cumprimento das metas (objetivos), com base na magnitude dos impactos ambientais (e riscos) gerados pelas atividades. É claro que essa análise deve ser preliminar e relativamente grosseira, feita apenas para não gerar uma política ambiental muito fora da realidade, pois a análise detalhada e final será feita ao ser cumprido um primeiro ciclo completo de implementação do SGA. 


\subsubsection{Recursos para implementação}

Haverá a necessidade de montagem de uma infra-estrutura para se conseguir implementar o Sistema de Gestão Ambiental, em termos de recursos humanos, recursos materiais e determinação de um modo de trabalho adequado.

$\mathrm{O}$ dirigente que possua o nível mais elevado na organização deverá ser o responsável pelo estabelecimento do Sistema de Gestão Ambiental. Sem essa responsabilização e comprometimento, o sistema poderá perder eficiência. Essa responsabilidade não poderá ser delegada.

Deverá existir uma preocupação dos dirigentes de níveis mais elevados de que sejam implementados princípios que introduzam, na rotina diária das pessoas, boas práticas de trabalho, com ferramentas adequadas de informação para a realização de trabalhos com elevada qualidade.

Esse apoio visível e ativo, com uma forte liderança e comprometimento são fundamentais para o sucesso do Sistema de Gestão (IAEA, 2004b). Os gerentes deverão divulgar as suas crenças e reforçar a política por meio de seu próprio comportamento individual e práticas gerenciais.

Os seguintes tipos de recursos são necessários:

a) Recursos humanos

Dependendo do porte da organização, será importante implantar uma área funcional com responsabilidade direta na gestão ambiental. Esse setor pode ser pequeno, com poucos especialistas, que atuariam como consultores de outras áreas e se preocupariam em "fazer o plano andar". Para chefiar essa área, o dirigente da organização deverá nomear uma pessoa de nível gerencial, para ser responsável pela implementação do Sistema de Gestão Ambiental. Essa pessoa terá as seguintes funções:

- coordenar o desenvolvimento e implementação do Sistema de Gestão, as auditorias e melhoramentos;

- promover programas de treinamento e implementar processos de comunicações;

- relatar sobre o desempenho do Sistema de Gestão, inclusive quanto à influência da cultura de segurança e qualquer necessidade de melhoria;

- resolver conflitos no Sistema de Gestão.

Trabalhando em sintonia com os especialistas da área de gestão ambiental, devem ser agregadas pessoas de outros setores da organização envolvidos com a questão ambiental, designados como "facilitadores", formando um Comitê ou Grupo de Trabalho. 
Essas pessoas trabalhariam em tempo parcial no apoio à implementação do plano, representando as posições de seus departamentos e áreas, retornando das reuniões com ações a serem realizadas por esses departamentos. Não haveria subordinação dessas pessoas ao Gerente Ambiental, apenas uma designação para participação no Grupo. Para a implantação do setor ambiental, eventualmente, será necessário rever os organogramas, regulamentos internos, definir funções e responsabilidades, implantar mecanismos de controle de custos (centros de custo) para apropriação de despesas relacionadas ao plano. A implantação do plano pode ser feita por etapas, para facilidade de controle, pois ela depende do grau de maturidade da organização: se o sistema gerencial que está operando tiver um bom nível, fica mais fácil implementar um SGA. E, se possível e viável, é interessante escolher uma unidade relativamente pequena, ou processo mais simples, para aplicar o SGA como um piloto, aprendendo-se a resolver os problemas existentes e consolidando uma "cultura" na organização. E, posteriormente, usar essa experiência em unidades ou sistemas maiores, com as próprias pessoas que praticaram os conceitos auxiliando e orientando os colegas.

Os gerentes de nível intermediário deverão ser responsabilizados para assegurar que o pessoal que trabalha sob sua supervisão tenha recebido um treinamento adequado, recursos e orientação. Esses treinamentos devem ser fornecidos antes do início dos trabalhos (IAEA, 2004b).

Deverá ser implementado um processo estruturado e transparente de tomada de decisão, em todos os níveis da organização.

A organização deverá identificar se as necessidades das pessoas e suas expectativas estão sendo atendidas, visando promover a satisfação no trabalho e o desenvolvimento profissional e pessoal. Essa atenção ajuda a assegurar que o envolvimento e motivação das pessoas serão um ponto forte da organização. (IAEA, 2004b).

b) Recursos materiais.

Estes irão compreender os locais de trabalho necessários aos componentes da equipe, com todos os recursos de apoio (computadores, materiais de trabalho, transporte, comunicações etc.). Além disso, poderá ser necessário o uso de equipamentos de monitoração de processos (hardware e software), e o emprego de equipamentos e medidores para inspeções e testes, entre outros. 


\subsubsection{Identificação de Requisitos Legais}

A Norma ISO 14.001 fixa a exigência de que a organização deva estabelecer e manter procedimentos para identificar e ter acesso à legislação e outros compromissos de desempenho assumidos subscritos pela empresa (por exemplo, com a adesão ao sistema designado como "Compromisso Empresarial para o Desenvolvimento Sustentável"), que sejam aplicáveis aos aspectos ambientais de suas atividades, produtos e serviços (ABNT, 2004).

Para que não exista o risco de que não sejam cumpridos os requisitos legais, por falta de conhecimento ou desorganização de seus registros, será necessária a realização de um trabalho para identificar as leis promulgadas, decretos que se aplicam ao desempenho ambiental e, em seguida, que seja criado um banco de dados com essas informações, que permita o acesso rápido a esses requisitos legais. Para que esse trabalho seja bem elaborado, será necessário que sejam previstos alguns procedimentos que auxiliem a garantir a identificação e cumprimento dos requisitos da legislação. Inicialmente, porque toda organização precisa, no mínimo, cumprir os requisitos legais do país, estado e município e, além disso, lembra-se que foi declarado explicitamente no texto da Política Ambiental o compromisso em cumprir a legislação.

Para isso, os procedimentos devem indicar a responsabilidade pelo trabalho de compilar as leis, resoluções e deliberações que se aplicam àquela determinada atividade produtiva ou de serviços. Realizando um controle organizado de acesso (lista das leis, arquivamento de cópia em pastas ou arquivos eletrônicos), deve-se implantar um mecanismo de divulgação aos setores afetados, realizar treinamentos no assunto e, em seguida, elaborar listas de verificação (check lists) com os requisitos aplicáveis, de forma a programar auditorias para verificar o cumprimento desses requisitos. Dessas auditorias, certamente resultarão pontos não cumpridos, que demandarão outras ações de correção. De qualquer forma, terá sido atingido o objetivo de identificar esses pontos para que estes possam ser corrigidos. A realização dessas auditorias, consolidada em registros e relatórios, demonstrará o cumprimento das leis ou indicará não-conformidades que irão requerer ações corretivas e preventivas, e protegerá os gerentes e diretores da empresa em tribunais, na ocorrência de acidentes e incidentes (pela demonstração de interesse em 
tomar as ações preventivas e corretivas), resultando em uma atividade muito útil do Sistema de Gestão Ambiental para a empresa e seus Diretores.

É importante esse trabalho de acompanhamento da legislação ambiental, com a listagem de todas as leis e regulamentos (em níveis federal, estadual, municipal) que tenham alguma relação com as atividades e serviços. Esse material deve ser constantemente atualizado, divulgando-se as informações aos colaboradores (comunicação por escrito, seguindo um procedimento específico), aos quais caberá comparar o desempenho específico com aquilo que estiver estabelecido nos requisitos legais e outros. Esta documentação deve ser guardada em um único local, com um sistema centralizado de controle, para maior garantia de atualizações. O sistema gerencial precisa possuir mecanismos para garantir que a lei está sendo cumprida (por exemplo, listas de verificação, diretrizes, controle de rastreabilidade das informações).

Os requisitos legais não atendidos devem ser tratados de acordo com os procedimentos estabelecidos para a tomada de ações corretivas.

Outra atividade típica do grupo responsável pelo cumprimento de requisitos legais é a verificação dos requisitos de licenciamento. Se a organização exerce atividades potencialmente poluidoras, ela precisou passar pelo processo de licenciamento junto aos órgãos ambientais. Ela precisou preparar Estudos de Impacto Ambiental e Relatório de Impactos sobre o Meio Ambiente (EIA-RIMA), passar por audiências públicas e recebeu as licenças necessárias (Licença Prévia, Licença de Instalação e Licença de Operação). Essas licenças ambientais têm validade, precisam ser publicadas e, então, uma das tarefas do setor é verificar se elas continuam válidas e, caso seja necessário, interagir com o órgão ambiental para deixar sempre regularizada a situação, além de arquivá-las cuidadosamente. Ela precisa estar cadastrada no órgão ambiental fiscalizador e apresentar um responsável técnico junto a esses órgãos. Também será necessário verificar freqüentemente se os compromissos assumidos no EIA-RIMA (medidas mitigadoras etc.) estão sendo observados. Se houver alguma mudança no processo produtivo, essa modificação terá que ser comunicada e aprovada.

Apresentamos, a seguir, uma sugestão de procedimento para realizar esse trabalho de identificação dos requisitos legais (e manutenção desse processo) pelos próprios participantes do Grupo de Trabalho encarregado da implantação do SGA. 
a) Acesso e identificação dos requisitos legais

O Grupo de Trabalho deverá, em conjunto e por divisão de trabalho entre seus membros, identificar as leis e demais requisitos aplicáveis aos aspectos ambientais identificados, preparando e mantendo atualizada uma Lista de Requisitos Legais.

Em sequência, deverá ser feita uma divisão de trabalho, para que cada participante do Grupo examine, em detalhes, cada capítulo e inciso da legislação, extraindo os pontos onde fique evidenciada uma necessidade de ação para que o requisito legal seja cumprido. Preferencialmente, esse trabalho deverá ser realizado pelo componente do Grupo de Trabalho que elaborou ou examinou os fluxogramas de processo utilizados na identificação dos aspectos e impactos ambientais, assunto que será comentado mais adiante nesta dissertação.

Observado um item eventualmente não cumprido, este deverá ser transcrito para um formulário de registro.

b) Comunicação dos requisitos aos colaboradores

Após terem sido preparados, os registros de "Identificação dos Requisitos Legais", estes serão analisados pelo Grupo de Trabalho do SGA, sendo tomadas as ações necessárias, quais sejam:

- elaboração de projetos/atividades pelo Grupo de Trabalho no Plano de Ação, quando coerentes com os objetivos e metas estabelecidos;

- elaboração de Procedimentos e Instruções de Trabalho que visem orientar o cumprimento do requisito legal considerado;

- preparação do relatório à alta administração quando não for possível a realização das ações previstas em (a) ou (b) acima.

Após a preparação dos procedimentos ou instruções de trabalho, deverá ser previsto e realizado um treinamento formal de todos os colaboradores envolvidos com o cumprimento da conformidade legal considerada.

Sugere-se que o Programa de Auditorias do SGA contemple uma verificação semestral do cumprimento dos requisitos identificados nos registros da "Identificação de Requisitos Legais", por um período no mínimo de dois (2) anos, bem como no Procedimento ou Instrução de Trabalho, estabelecidos para cumprimento desse requisito. 
c) Acompanhamento dos requisitos legais

Após a implantação inicial do SGA, caberá ao Gerente de Meio Ambiente (ou cargo semelhante na organização) lançar tarefas para que os colaboradores realizem uma atualização da Lista de Requisitos Legais, bem como do trabalho descrito no item acima. Como sugestão, essa ação deverá ser tomada pelo Gerente de Meio Ambiente a cada 6 meses. A Figura 3.3 propõe um formulário que poderá auxiliar a realização deste trabalho. 


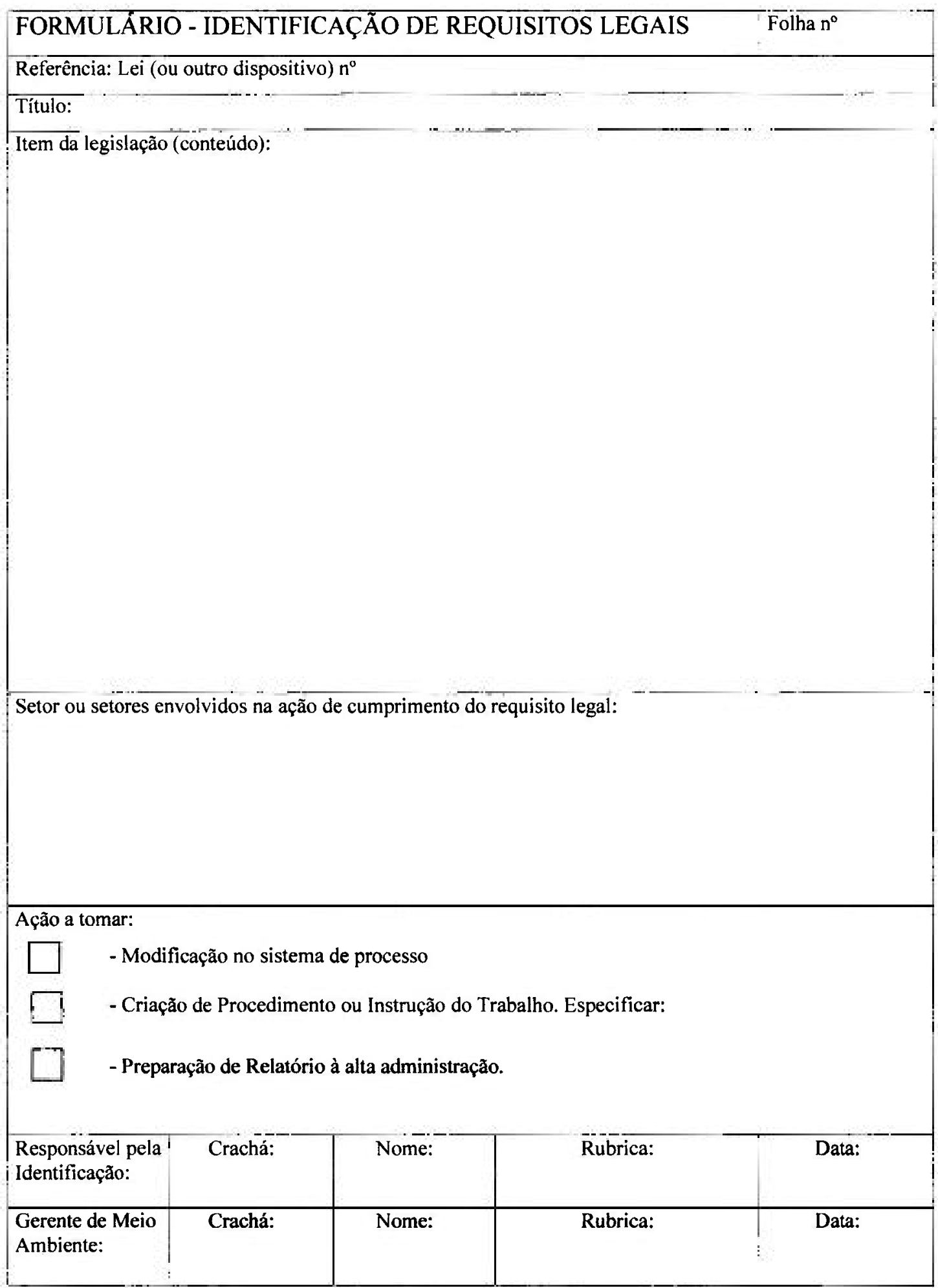

Figura 3.3 - Formulário sugerido para identificação dos requisitos legais 


\subsubsection{Aspectos e impactos ambientais}

Aspectos ambientais são todos os elementos das atividades de uma organização, de seus produtos ou serviços, que podem interagir com o meio ambiente. Como exemplos de aspectos ambientais em um produto ou processo, temos: matéria prima, consumo de água e energia, embalagem utilizada e emissão de efluentes.

Impactos ambientais: são quaisquer mudanças no meio ambiente (adversas ou benéficas) que ocorrem como resultado das atividades, produtos ou serviços de uma organização. A idéia de impactos ambientais é quase sempre associada à geração de eventos indesejáveis, ou seja, agressões ao meio ambiente.

A norma ISO 14001 (ABNT, 2004) define que a organização deve estabelecer e manter procedimentos para identificar os aspectos ambientais de suas atividades, produtos ou serviços que possam por ela ser controlados e sobre os quais se presume que ela tenha influência, a fim de determinar aqueles que tenham ou possam ter impacto significativo sobre o meio ambiente. A organização deve, ainda, assegurar que os aspectos relacionados a estes impactos significativos sejam considerados na definição de seus objetivos ambientais.

A identificação dos aspectos e impactos ambientais é importante para a realização da avaliação de desempenho ambiental da organização. Conforme comentamos anteriormente, um dos primeiros passos a serem realizados, antes de propriamente iniciar a implantação de um Sistema de Gestão Ambiental (ou mesmo apenas investir em melhorias isoladas, sem pretender implantar um SGA) é o de avaliar a situação atual da organização no tocante ao seu desempenho ambiental, realizar uma "fotografia" da situação, ou seja, responder à pergunta "onde estamos". Desempenho ambiental é entendido como sendo o conjunto de resultados alcançados com a gestão dos aspectos ambientais da organização. Essa avaliação é, na realidade, uma ferramenta gerencial para auxiliar a identificar e avaliar, com realismo e objetividade, se os processos produtivos, produtos e serviços estão de acordo com os padrões estabelecidos pela alta administração na Política Ambiental, pela legislação ou outros documentos e compromissos assumidos pela organização. A avaliação, feita nesta fase inicial, deve ser depois repetida ao longo do desenrolar das atividades, com a coleta de dados, sua análise e realização de registros, com o propósito de bem conhecer o problema e permitir fixar, de forma realística, os objetivos e metas, dentro de um processo de melhoria e aperfeiçoamento contínuos. Posteriormente, a avaliação de desempenho 
ambiental será verificada e refeita com mais dados pelas auditorias ambientais, internas e externas, para a verificação de "conformidades".

Deve ser preparada uma lista contendo todos os aspectos ambientais identificados e associados a impactos, com o propósito de fornecer subsídios à tomada de decisões quanto à priorização de soluções visando eliminar ou mitigar os impactos (redução das consequiências).

A organização deverá iniciar a identificação dos aspectos ambientais verificando as condições de operação normal da planta industrial. Porém, mais adiante, ela deverá considerar também os aspectos que ocorrem nas situações anormais de operação e nas condições de emergência, avaliando os possíveis acidentes que poderiam ocorrer. Deverá ser mantido um controle das interfaces com os fornecedores e clientes, de modo a identificar com clareza as responsabilidades dos impactos, sobretudo os indiretos.

Um processo é um conjunto de atividades inter-relacionadas. A partir de certas entradas, tais como materiais, mão-de-obra e energia, são produzidos resultados, que podem ser produtos finais ou intermediários, serviços, resíduos, energia ou outras saídas. Mas o processo industrial, para ser bem compreendido e analisado, precisa ser subdividido em partes menores. Entendendo-se as partes menores e a sua relação com as partes precedentes e subseqüentes poderemos bem compreender o processo. $O$ "fluxograma de processo" é uma ferramenta que representa essa quebra do processo. E também é uma das ferramentas mais interessantes para auxiliar na identificação dos aspectos e impactos ambientais. Indicando em cada bloco (na verdade uma quebra do processo em partes menores) as entradas de materiais e energia e as saídas de materiais e energia (entre os materiais os resíduos sólidos, líquidos e gasosos), estaremos identificando os aspectos e impactos ambientais.

Recomendamos que a equipe de gestão ambiental conheça bem os processos da empresa que possam gerar poluição. Esse conhecimento deve ser obtido estudando-se os documentos de engenharia (projetos, especificações dos sistemas, fluxogramas de engenharia), mas, principalmente, que seja construído um "fluxograma de processo", acompanhando-se o processo "no campo", perguntando-se aos técnicos que controlam as máquinas e o processo como funciona o sistema, como ocorre a transformação de matérias primas em produtos, ou como se desenvolve um serviço. Com esse método, será difícil que alguma emissão de poluentes fique despercebida.

A produção de resíduos e poluentes, em muitos casos, é resultado de falhas no processo, principalmente se os valores estiverem em níveis excessivos, ou seja, fora dos 
limites previstos nas leis, regulamentos ou normas (externas ou internas à organização). Essa produção de resíduos configura-se, assim, como uma conseqüência anormal ou problema, cujas causas precisam ser bem identificadas, para que seja possível tomar as medidas corretivas.

Uma ferramenta da qualidade total bastante útil, que pode ser usada para esta finalidade, é o "diagrama de causa e efeito", ou "diagrama de Ishikawa" (em homenagem ao Prof. Kaoru Ishikawa, seu idealizador), ou ainda "diagrama de espinha de peixe" (pela sua forma de apresentação). Esse diagrama registra, em um retângulo à direita (exemplo da Figura 3.4), a conseqüência indesejável do processo ou problema, ou "efeito ambiental" indesejável, do qual se pretende determinar as causas. Ligado a um eixo central, são desenhados seis eixos, cada um registrando um dos possíveis enquadramentos de causas genéricas de problemas, chamadas de "fatores de manufatura" ou "fatores de serviços", conforme o caso, todos iniciados com a letra "M", razão pela qual o diagrama também é chamado de "6Ms", e que representam grandes grupos de causas: Matérias Primas, Máquinas, Métodos, Mão-de-Obra, Meio Ambiente e Medidas. Esse seria um diagrama genérico, podendo-se, se houver uma idéia melhor, usar o diagrama com outras categorias de variáveis mais específicas e representativas do problema.

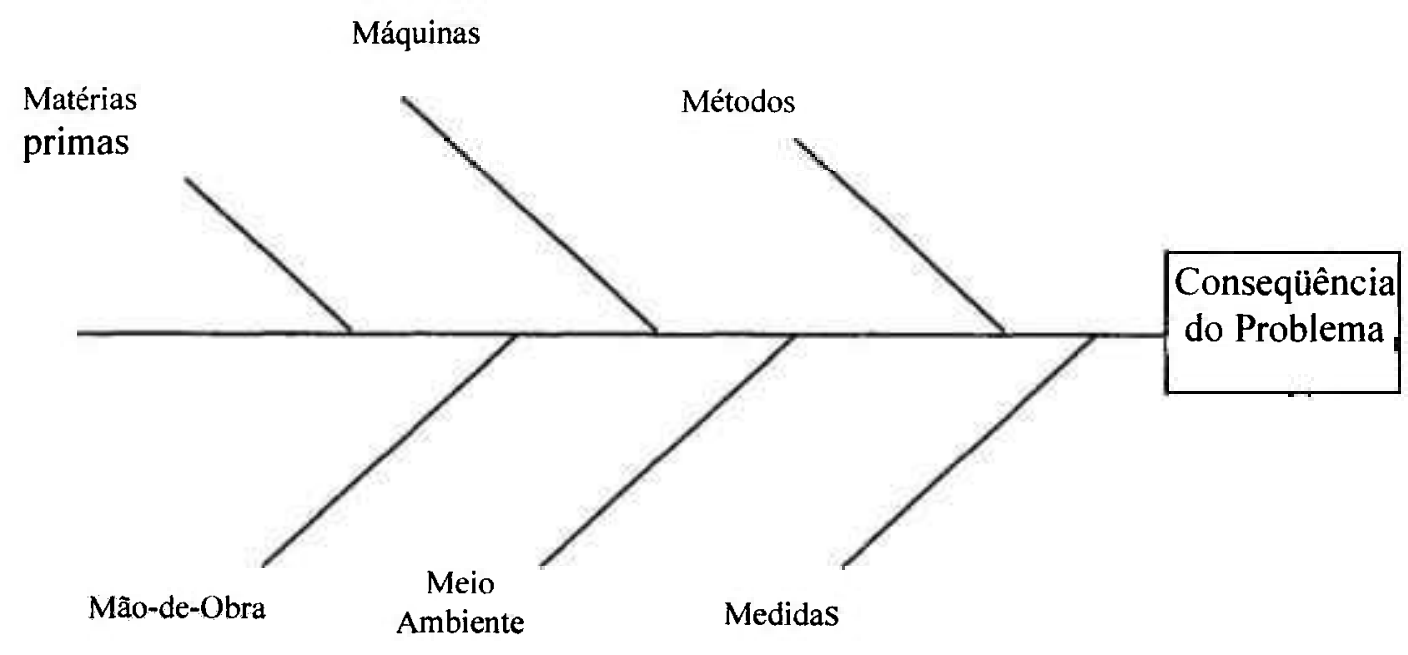

Figura 3.4 - Diagrama de Ishikawa

Em cada uma dessas categorias, identificadas por um trabalho de observação direta do processo, feito pelos profissionais ligados ao projeto ou operação daquela unidade particular sob análise, deverão ser exploradas e identificadas cada uma das possíveis causas, sendo registradas no diagrama. 
Ao ser implantado um SGA em uma determinada organização, uma das dificuldades que provavelmente terá que ser vencida pela equipe será a de definir uma prioridade para a solução dos impactos ambientais. Existirão dezenas ou centenas de impactos identificados, havendo a necessidade de que seja definida uma prioridade ou ordem de execução, já que não existirão recursos financeiros nem tempo para a realização de todas as atividades necessárias. Então, a ferramenta denominada "matriz de risco", que será vista a seguir, pode ser uma idéia interessante para indicar essa prioridade, com base nos riscos que os impactos ambientais apresentam.

$\mathrm{E}$, quando se pensa em riscos, sempre será necessário avaliar duas variáveis que compõem o risco:

a) a gravidade da consequiência daquele evento ou impacto, ou severidade, que dará uma graduação das consequiências, desde a morte de pessoas até conseqüências desprezíveis para pessoas e o meio ambiente, na ocorrência do evento ou daquele determinado impacto ambiental considerado;

b) a probabilidade ou freqüência de ocorrência daquele determinado impacto ambiental. A freqüência é avaliada quando se trata de um impacto que ocorre com uma certa constância (por exemplo, o lançamento de um determinado efluente industrial em um curso d'água), enquanto a probabilidade é considerada nos impactos potenciais (normalmente não ocorrem).

A "matriz de risco" se revela, dessa forma, como uma ferramenta interessante para priorizar os impactos ambientais. Veremos a forma de construí-la.

As categorias de gravidade (severidade) são definidas para indicar uma medida qualitativa do pior evento que esteja ocorrendo ou com risco de ocorrer, resultante de erros do operador, condições ambientais, projeto inadequado, procedimentos inadequados ou falhas e mau funcionamento de sistemas, subsistemas ou componentes: 
Tabela 3.1 - Categorias de gravidade dos impactos ambientais
Descrição
Categoria
Definição

\begin{tabular}{lcl}
\hline CATASTRÓFICA & I & $\begin{array}{l}\text { Coloca em perigo a vida das pessoas ao redor da área, } \\
\text { como resultado dos produtos e processos envolvidos. } \\
\text { Riscos elevadíssimos para o meio ambiente. } \\
\text { CRÍTICA }\end{array}$ II $\begin{array}{l}\text { Ameaça a saúde das pessoas que vivem ao redor da área. } \\
\text { Sério prejuízo ao meio ambiente em casos de acidentes. } \\
\text { Não conformidade com requisitos legais. Consumo } \\
\text { significativo de recursos naturais. }\end{array}$ \\
MARGINAL & III $\quad \begin{array}{l}\text { Não conformidade com requisitos internos (normas). } \\
\text { Prejuizo moderado ao meio ambiente. Não conformidade } \\
\text { com a política ambiental da organização. Possível prejuízo } \\
\text { à reputação da empresa. Consumo moderado de recursos } \\
\text { naturais. } \\
\text { Impacto baixo ou muito baixo sobre o meio ambiente. } \\
\text { Evento dificilmente detectado. }\end{array}$ \\
DEPREZÍVEL & IV
\end{tabular}

A frequiência de ocorrência de impactos ambientais, para condições normais e anormais de operação, ou a probabilidade de ocorrência do impacto ambiental no caso em que a análise esteja sendo feita para identificar riscos, é determinada por pesquisa, análise e avaliação do desempenho histórico do sistema (ou de sistemas semelhantes), podendo ser descrita em ocorrências reais ou potenciais por unidade de tempo, eventos, população, itens ou atividades. A classificação pode ser feita nas seguintes categorias:

Tabela 3.2 - Níveis de freqüência ou probabilidade de ocorrência

\begin{tabular}{lcl}
\hline \multicolumn{1}{c}{ Definicão } & Nível & \multicolumn{1}{c}{ Descrição } \\
\hline FREQÜENTE & A & $\begin{array}{l}\text { Ocorre freqüentemente (ou alta probabilidade), ou ocorre } \\
\text { permanentemente quando iniciada a atividade. }\end{array}$ \\
PROVÁVEL & B & $\begin{array}{l}\text { Irá ocorrer várias vezes na vida do sistema ou do item. } \\
\text { Irá ocorrer algumas vezes ao longo da vida do sistema ou } \\
\text { OCASIONAL }\end{array}$ \\
REMOTA & D & $\begin{array}{l}\text { Não se espera que ocorra (embora haja alguma } \\
\text { expectativa) ao longo da vida do item ou sistema. } \\
\text { Pode-se assumir que não irá ocorrer, ao longo da vida do } \\
\text { sistema ou do item. }\end{array}$ \\
IMPROVÁVEL & E
\end{tabular}

A combinação dos dados de frequiência ou probabilidade com os de gravidade das conseqüências gera a matriz de risco (Figura 3.5). Para a utilização desta matriz devem ser avaliadas, para cada impacto a gravidade das conseqüências e a freqüência ou probabilidade de ocorrência daquele impacto específico e registrar o impacto na matriz (Fig.3.5). 


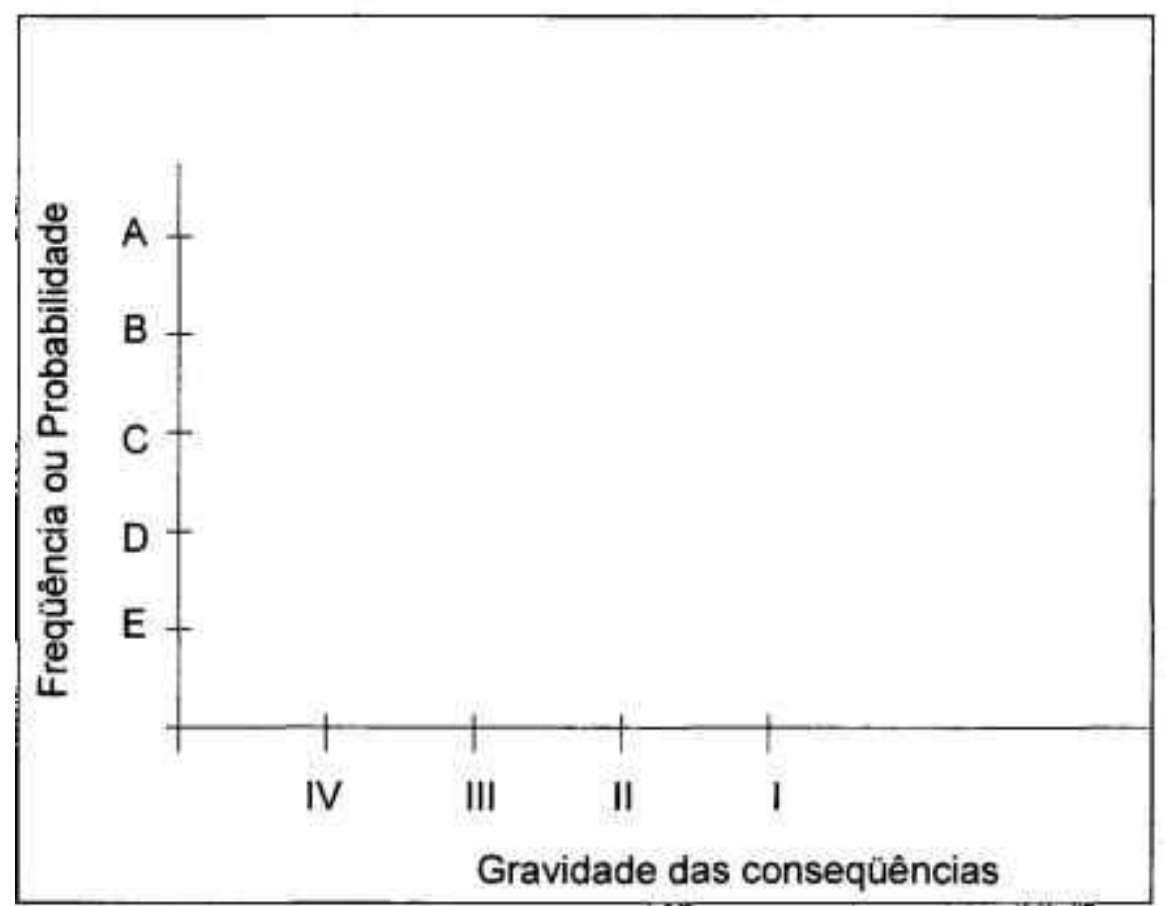

Figura 3.5 - Matriz de Risco

Observando-se os registros, serão identificadas regiões onde ocorre uma associação de situações de alta gravidade com probabilidade de ocorrência que sejam consideradas altas (condições inaceitáveis, quando cuidados mais expressivos deverão ser tomados, com ações para reduzir os riscos, modificando-se os sistemas), regiões onde é prudente realizar ações de gerenciamento de riscos, e outras regiões onde as condições são aceitáveis.

Uma outra possibilidade a ser considerada é agregar à análise uma terceira variável, ou seja, definir a extensão dos impactos, com a possibilidade de quatro enquadramentos:

- os impactos restringem-se somente ao local de ocorrência;

- os impactos restringem-se aos limites físicos da empresa;

- os impactos atingem a região adjacente à empresa;

- os impactos atingem amplas áreas externas à empresa.

Outra recomendação é de que os aspectos identificados sejam comparados com as exigências legais ou regras e regulamentos da empresa, além de outras avaliações que deixam o processo de priorização mais completo.

Em linhas gerais, sugere-se que sejam usados os mesmos procedimentos já apresentados, ou seja, usarmos o fluxograma de processo e a "matriz de risco", porém 
agregando informações que reflitam também a questão do atendimento à legislação aplicável e outras informações, com uma nova pontuação, conforme apresentado na planilha da Figura 3.6. 


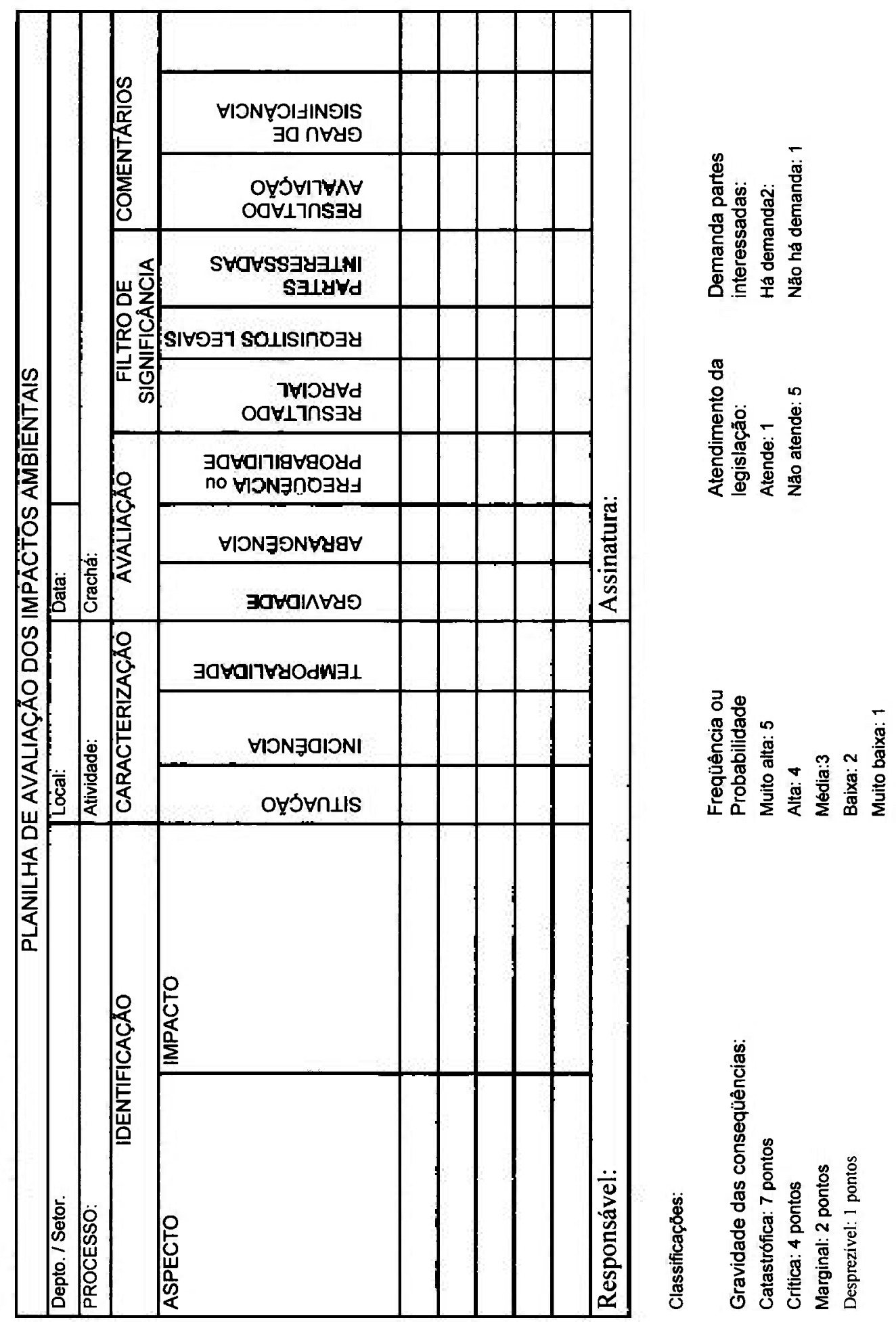

Figura 3.6 - Planilha de avaliaçăo dos impactos ambientais 
Para o preenchimento da planilha, são apresentadas sugestões de pontuação e registro de informações, com base na experiência:

\section{a) CARACTERIZAÇÃO DO IMPACTO}

a1) Situação. Refere-se a um indicativo para mostrar se o impacto é esperado, continuado ou referente a situações mais difíceis de serem observadas:

Regime Normal $(\mathrm{N})$ - relativos ao regime de operação normal (rotineiro), que ocorre com o funcionamento rotineiro das máquinas e processos empregados durante a realização normal dos serviços.

Eventual (E) - impactos eventuais, não existentes na condição normal de operação, mas que podem ocorrer em condições de partida de equipamentos da instalação, condições de parada (ao ser desligado o equipamento, podem ocorrer liberações intempestivas), ou durante manutenções (uso de solventes e outros materiais poluentes, descarte de peças gastas ou contaminadas etc.). Podemos classificar, neste item, as situações de risco, ou seja, impactos potenciais (acidentes, colapso operacional) e também impactos imagináveis como resultantes de manifestações da natureza (terremotos, enchentes etc.).

a2) Incidência. Trata-se de um indicativo (não pontuado), que irá refletir se a responsabilidade direta pela geração daquele determinado impacto é da própria organização, ou de organizações contratadas por ela.

Direta (D) - impacto associado a uma determinada atividade executada pela própria organização;

Indireta (I) - impacto associado a uma atividade realizada por empresas contratadas, fornecedores de material, prestadores de serviços e outras empresas que utilizam eventualmente as instalações e serviços da nossa organização, sobre as quais ela pode exercer influência.

a3) Temporalidade. Também um indicativo não numérico, que permite que o observador avalie quando aquele determinado impacto foi gerado.

Passado $(\mathrm{P})$ - impacto identificado no presente, porém resultante de atividade desenvolvida pela organização no passado (que tenha gerado algum passivo);

Atual (A) - impacto decorrente de atividade realizada no presente;

Futuro (F) - impacto previsto para ocorrer no futuro, como resultado de atividades previstas, provavelmente em instalações ainda não construídas, porém já 
projetadas. Como sugestão para identificar estes impactos, sugere-se consultar o EIARIMA, caso ele tenha sido feito, para aquela instalação.

\section{b) AVALIAÇÃO DO IMPACTO}

É proposta, a seguir, uma classificação um pouco mais completa das "gravidades das conseqüências" e da "probabilidade ou frequiência", em relação àquela apresentada anteriormente neste capítulo.

b1) Gravidade das consequiências. Esta avaliação visa definir, para o impacto considerado, quais são as consequiências para o meio ambiente. Nas classificações sugeridas, a seguir, foram descritos vários elementos, como o tipo de poluição produzida, o custo de recuperação após um acidente, entre outros. Deve-se enquadrar o impacto em um ou mais elementos de cada categoria, escolhendo aquela que se apresente como a mais adequada. Nota: os tipos de classificação, ou mesmo a descrição de cada tipo, podem ser criados pela equipe da própria organização, pois a Norma ISO 14.001 não fixa nenhum critério a este respeito.

Catastrófica ou muito alta: pode causar a morte de uma ou mais pessoas, como resultado dos produtos e processos envolvidos. Impactos elevadíssimos para o meio ambiente. Liberação de quantidades significativas de contaminantes para o meio ambiente (solo, águas e atmosfera). Esgotamento de um recurso natural. Extinção de uma espécie. Eventos que causem prejuízos (reparos) de substituição da ordem de $25 \%$ (ou superiores) em relação ao valor da instalação. Recuperação após um acidente ou avaria com prazo superior a 6 meses.

Crítica ou alta: pode causar ferimentos ou doenças graves. Sério prejuízo ao meio ambiente. Exposição a agentes tóxicos acima de valores estabelecidos por critérios específicos. Contaminação interna da planta, do solo, de águas e do ar, em níveis cerca de $10 \%$ acima dos valores permitidos pela legislação ambiental. Consumo exagerado de recursos naturais. Custos de recuperação da instalação entre $2 \%$ e $25 \%$ do custo total. Recuperação da instalação entre 3 e 6 meses.

Marginal ou baixa: Pode causar ferimentos ou doenças de gravidade baixa. Não conformidade com requisitos internos (normas). Prejuízo moderado ao meio ambiente. Não conformidade com a política ambiental da organização. Possível prejuízo à sua reputação. Contaminação interna à planta e mínima contaminação do solo. Consumo 
moderado de recursos naturais. Interrupções de parte da instalação para reparos por um período inferior a 90 dias. Custos de recuperação da ordem de $1 \%$ do valor da instalação;

Desprezivel: impacto baixo ou muito baixo sobre o meio ambiente. Evento dificilmente detectado. Não causa ferimentos ou doenças. Recuperação de parte avariada em período inferior a 15 dias. Custos de recuperação inferiores a $1 \%$ do valor da instalação.

Sugestões de pontuação:

Catastrófica: 7 pontos

Crítica: 4 pontos

Marginal: 2 pontos

Desprezível: 1 ponto

b2) Abrangência. Este item visa pontuar o alcance do impacto, em termos geográficos. Pontuações mais altas, ou seja, aquelas referentes a impactos que atingem áreas externas, colaborarão para que seja atribuída uma maior prioridade em sua solução.

Baixa (B) - impacto restrito ao local da ocorrência, às proximidades do gerador;

Média (M) - impacto que extrapola o local da ocorrência, mas que permanece dentro dos limites da organização;

Alta (A) - impacto que extrapola os limites da organização, atingindo áreas externas.

Sugestão de pontuação:

B - 1 ponto

M - 2 pontos

A - 3 pontos

b3) Freqüência ou probabilidade de ocorrência do impacto considerado. Esta é uma das variáveis de maior importância no julgamento de um impacto ambiental. Os pontos atribuídos deverão favorecer a solução de impactos que ocorram com maior freqüência, ou aqueles que, em situações de risco potencial, apresentam uma maior probabilidade de ocorrência. As classificações sugeridas são:

Muito alta: ocorre freqüentemente (ou alta probabilidade), ou ocorre permanentemente quando iniciada a atividade, em situação normal de operação. Em eventos potenciais, probabilidade maior ou igual a 1 caso por ano; 
Alta: irá ocorrer muitas vezes na vida do sistema ou item avaliado. Em situações de risco (eventos potenciais), as probabilidades avaliadas são menores que 1 e maiores ou iguais a $10^{-2}$ casos por ano;

Média: irá ocorrer algumas vezes ao longo da vida do sistema ou do item. Em situações de risco (eventos potenciais), ocorre com probabilidades menores que $10^{-2} \mathrm{e}$ iguais ou superiores a $10^{-4}$ casos por ano;

Baixa: não se espera que ocorra (embora haja alguma possibilidade) ao longo da vida do item ou sistema. Possibilidade remota de ocorrer aquele impacto. Em situações de risco (eventos potenciais), com probabilidades menores que $10^{-4}$ e iguais ou superiores a $10^{-6}$ casos por ano.

Muito baixa: pode-se assumir que não irá ocorrer, ao longo da vida do sistema ou do item. Em situações de risco (eventos potenciais), com probabilidades inferiores a $10^{-6}$ casos por ano.

Sugestōes de pontuação:

Muito alta: 5 pontos

Alta: 4 pontos

Média: 3 pontos

Baixa: 2 pontos

Muito baixa:1 ponto

\section{b4) Resultado parcial}

Podemos obter um resultado parcial da avaliação do aspecto/impacto considerado, que nos dará uma pontuação dos itens avaliados até esta fase, multiplicandose o valor do índice atribuido à FREQÜÊNCIA/PROBABILIDADE, com a soma dos índices GRAVIDADE e ABRANGÊNCIA.

c) FILTRO DE SIGNIFICÂNCIA. A aplicação de um filtro de significância é útil para permitir que sejam levados em conta alguns requisitos especiais, como o cumprimento da legislação, por exemplo. Neste caso, quando se observar que o impacto viola alguma lei, devem ser atribuídos pontos (pesados, neste caso), para que esse impacto acabe recebendo uma prioridade elevada para a sua solução.

c1) Requisitos legais: não cumprir a legislação é grave em qualquer organização, pois além de sujeitá-la a sanções diversas, existe a questão das repercussões na sociedade, na eventualidade de um acidente ou incidente com liberação de produtos. $\mathrm{E}$ 
também por comprometer a certificação, já que os auditores abrirão uma não conformidade pelo descumprimento da Politica Ambiental (onde foi declarado, como um dos compromissos, o cumprimento da legislação).

Sugestões de pontuação:

Atende: 1

Não atende: 5

c2) Demanda de partes interessadas. Partes interessadas, segundo a Norma ISO 14.001, "são os indivíduos ou grupos interessados no desempenho ambiental de uma organização", ou seja, os vizinhos, membros de ONGs, órgãos ambientais, mídia e outros. $\mathrm{Na}$ avaliação deste tópico, visamos influenciar a pontuação final dos impactos que chamam mais a atenção das partes interessadas.

Sugestão de pontuação:

Não há demanda: 1

Há demanda: 2

\section{d) Resultado da avaliação.}

O resultado da avaliação poderá ser obtido por meio de um cálculo, onde somaremos os pontos atribuídos a "Requisitos legais" com os pontos do item "Partes Interessadas". A seguir, podemos multiplicar o valor obtido pelo "Resultado Parcial" anteriormente calculado.

e) Grau de significância.

O grau de significância irá refletir, por meio de um enquadramento, os pontos obtidos pelos cálculos, separando os impactos em quatro categorias, às quais podemos atribuir prioridades para a sua solução.

Sugestões de enquadramento:

Efeito crítico (C): entre 350 e 260 pontos - prioridade 1

Efeito significativo (S): inferior a 260 pontos e igual ou superior a 170 pontos prioridade 2

Efeito reduzido (R): inferior a 170 pontos e igual ou superior a 80 pontos prioridade 3

Efeito desprezível (D): inferior a 80 pontos - prioridade 4 
Realizado esse trabalho, teremos um conhecimento grande dos impactos ambientais resultantes das atividades, produtos e serviços da organização. E teremos avaliado, com um método racional e rastreável, a prioridade com que devemos procurar eliminar ou reduzir os impactos para níveis aceitáveis. Nossa próxima etapa do SGA será a fixação de objetivos e metas.

\subsection{5 - Objetivos e Metas}

Objetivos ambientais são as metas globais de desempenho, originárias da política ambiental e da avaliação de efeitos e impactos significativos, que são estabelecidas por uma organização para si própria. Sempre que possível, os objetivos devem ser quantificados.

Metas ambientais são os requisitos detalhados de desempenho, sempre que possível sendo quantificados (metas mensuráveis), aplicáveis a uma organização ou parte dela, que se originam dos objetivos ambientais e que necessitam ser implementados de modo a atingir aqueles objetivos.

A norma ISO 14001 (ABNT, 2004) prevê que "a organização deve estabelecer e manter objetivos e metas ambientais documentados, em cada nível e função pertinentes da organização".

Os objetivos e metas devem ser específicos, coerentes com a política ambiental da organização, devem levar em conta os requisitos legais e outros códigos de conduta subscritos voluntariamente e devem colaborar para tornar realidade o comprometimento com a prevenção da poluição, estabelecido na Política Ambiental. Os objetivos são sempre metas de alto nível (gerais), enquanto as metas refletem exigências mais objetivas, mensuráveis sempre que possível. Também é possível que um objetivo, para que seja alcançado, tenha a necessidade de ser desdobrado em várias metas.

Conforme foi enfatizado, há a necessidade de que as metas sejam, sempre que possivel quantificadas, para remover a subjetividade quanto ao cumprimento. E, principalmente, há a necessidade de que sejam identificados os indicadores de desempenho ambiental, que se constituem em ferramentas para medir de forma objetiva os resultados, para garantir que a meta foi realmente cumprida. Em todos os processos, é necessário medir, para avaliar se os resultados apresentam, ao longo do tempo, melhorias de desempenho.

Na fixação dos objetivos e metas ambientais, será interessante considerar:

- redução de emissões radioativas; 
- redução de emissões não radioativas (tais como efluentes líquidos, gasosos e material sólido);

- prevenção da poluição;

- conservação de recursos (principalmente recursos naturais);

- minimização de rejeitos.

Alguns indicadores de desempenho ambiental que podem ser utilizados são:

- quantidade (ton) de resíduos sólidos estocados em um determinado periodo de tempo;

- quantidade de resíduos produzidos por $\mathrm{kg}$ de rejeito radioativo estocado;

- quantidade de energia utilizada por kg de rejeito estocado;

- quantidade de água utilizada por kg de rejeito estocado no período (ano);

- litros de água utilizada por funcionário, por ano;

- percentual de água reutilizada ou reciclada, em relação ao total utilizado de água;

- percentual de funcionários treinados em questões ambientais;

- percentual de funcionários que apresentam exigências ambientais na descrição de suas tarefas;

- percentagem de funcionários que participam de programas ambientais (por exemplo, sugestões de melhorias, programas de coleta seletiva, iniciativas de limpeza etc.);

- percentual de investimentos em melhorias ambientais em relação ao orçamento;

- número de objetivos e metas ambientais atingidos no ano;

- número de queixas da comunidade, por ano, relativas a problemas ambientais;

- quantidade de material perigoso utilizado no processo de produção;

- número de acidentes ambientais por ano;

- quantidade de exercícios de simulação de acidentes ambientais previstos e realizados no ano;

- número de incidentes ambientais por ano;

- percentagem das ações corretivas resolvidas em relação ao total de ações corretivas abertas;

- percentagem de fornecedores e prestadores de serviços que possuem certificação ISO 14.001; 
- tempo de reação das equipes, nas ações de resposta a emergências, em treinamentos de incidentes ambientais;

- número de ações corretivas identificadas;

- número de "não-conformidades" registradas nas auditorias ambientais (internas e externas);

- número de iniciativas relacionadas à redução de resíduos e ao aumento da reciclagem;

- percentual de combustível poupado em relação ao consumo total, como resultado de programas de uso racional de combustiveis.

\subsubsection{Plano de Ação}

Após terem sido definidos os objetivos e metas, a etapa seguinte consiste em planejar a implementação das diretrizes, realizando as modificações necessárias nos processos industriais que permitam atingir as metas, ou seja, definir com precisão o trabalho a ser realizado, os funcionários requeridos e as responsabilidades de cada um, os recursos necessários e o prazo de execução. O propósito das normas é garantir que, dentro da organização as metas, os objetivos e a própria política, sejam apoiados por um programa realista de implantação, sendo importante que esse programa esteja integrado ao plano estratégico da organização.

Os programas devem ser adaptados à atividade específica da área e os processos envolvidos, sendo revisados quando necessário. Por exemplo, o programa de uma instalação de armazenagem de rejeitos radioativos, cuja preocupação maior é com a segurança dos funcionários, do público externo e do meio ambiente, precisa ser mais exigente do que o de uma área administrativa da organização.

O Plano de Ação pode ter vários formatos, contendo as metas, as diretrizes, a forma de medida e um cronograma ou rede do tipo PERT de implementação de cada diretriz. Entre as várias metas possíveis, deve ser estabelecida uma prioridade de implantação pela alta administração (dependendo dos recursos envolvidos). Uma ferramenta interessante e simples para confecção e posterior gerenciamento do programa de gestão ambiental é o software "Project", da Microsoft. Porém, uma forma bastante prática, e ainda mais simples de elaboração desse plano, é construir um quadro com colunas, onde sejam abordadas as perguntas básicas denominadas " $5 \mathrm{~W} 1 \mathrm{H}$ ": 
-What: O que tem que ser feito? Quais são os aspectos ambientais e impactos ambientais que serão tratados?

-When: Quando será feito? Quais os prazos de execução de cada atividade planejada? Quais são as datas de início e fim previstas para cada atividade?

-Where: Onde serão executadas as ações programadas? Em qual setor da organização? Em qual processo?

-Why: Por que serão realizadas as ações? Quais são os requisitos legais que determinam a realização das ações?

-Who: Quem tem a responsabilidade de realizar aquela ação? Qual a pessoa ou a área da organização diretamente responsável pela ação a ser tomada?

-How: Como será realizada a ação necessária para atingir a meta? Qual o procedimento que terá que ser seguido para se chegar ao resultado pretendido? Nota: o próprio Plano de Ação define o "como fazer" para se atingir as metas estabelecidas, porém esta fase pode ser realizada de forma mais eficiente expandindo-se o planejamento, definindo-se tarefas bem específicas, por meio de Gráficos de Gantt, PERT-CPM etc., e não apenas os objetivos e metas globais. Poderá ser incluído no "How" uma coluna para que seja respondido o "How much", ou seja, apresentar sempre os custos e despesas envolvidas na realização daquele determinado Plano de Ação.

O Plano de Ação, por se apoiar em etapas anteriores, forçosamente deverá estar coerente com a Política Ambiental da organização e com seus objetivos. Se houver necessidade de maior aprofundamento das tarefas e atividades do Plano de Ação, poderá ser preparado um Programa de Gestão Ambiental, que apresentará um maior detalhamento das ações requeridas. Caso o conteúdo do plano já seja suficiente para a realização das ações, pode ser dispensada a elaboração do programa. O Programa de Gestão Ambiental deverá deixar bem claro de que forma as metas serão atingidas, com um detalhamento de todas as etapas (cronogramas detalhados), prioridades entre as ações, responsabilidades das pessoas envolvidas e interações entre elas (trocas de informações), necessidades de recursos (materiais e humanos), atividades de projeto, de produção (processos produtivos), de comissionamento, de garantia de qualidade e de uso e disposição final de produtos.

\subsection{As etapas de execução}

A implementação das ações e medidas planejadas na fase anterior requer: 
- designação pela alta administração de um representante específico para gerenciar o SGA e formar a equipe;

- definição clara das funções dos funcionários e colaboradores envolvidos, bem como das responsabilidades, por meio do Plano de Ação;

- previsão de recursos que estarão disponíveis para o programa, em função das necessidades identificadas no plano de ação, segundo uma determinada prioridade;

- documentação e comunicação do andamento do plano;

- comprometimento (por meio de palestras de motivação) de todos os níveis funcionais envolvidos;

- integração dos elementos do sistema de gestão ambiental com os outros elementos do sistema de gestão da organização.

Para a implementação do plano, será necessário mobilizar:

- recursos humanos, também denominados de "humanware", com pessoas específicas conhecedoras do assunto "meio ambiente", gerenciamento ambiental ou de higiene e segurança do trabalho, diretamente ligadas ao assunto meio ambiente, e também os funcionários de gerências e das áreas operacionais que participam das operações da organização, que possam causar efeitos ambientais. $O$ patrimônio que a organização dispõe do "humanware" é o conhecimento que as pessoas possuem do assunto, quase sempre difícil de ser obtido (envolve tempo de aprendizagem ou de experiência e, sobretudo, "vontade de aprender");

- recursos físicos, também denominados "hardware", ou seja, os sistemas, máquinas e instalações existentes ou a serem implementados para reduzir os impactos sobre o meio ambiente, conforme tenha sido planejado. $\mathrm{O}$ crescimento dos recursos físicos depende principalmente do aporte de capital (recursos financeiros);

- procedimentos, também denominados "software", que compõem o know-how da organização, expresso em normas internas, instruções de trabalho, rotinas operacionais e outras ações e hábitos de trabalho não documentados.

\subsubsection{Alocação de recursos financeiros}

A alta direção da organização deverá definir um orçamento a ser respeitado na implantação do programa de gestão ambiental, sem o qual não será possível cumprir aquilo que foi programado no plano de ação. A fixação desse orçamento será resultado das 
prioridades estabelecidas, ou seja, quais instalações deverão ser feitas naquele ano para atingir melhorias, quanto deverá ser gasto em treinamentos de pessoal, quais os investimentos para reduzir os riscos, alterações onde os desperdícios são mais significativos, conforme os objetivos e metas a serem atingidos e um plano de ação para a implantação dos empreendimentos.

Os recursos devem ser atribuídos nas quantidades necessárias e planejadas pois quando isso não ocorre, há muita perda de trabalho, de estudos e projetos, tempo utilizado em reuniões e na realização de planejamentos, que representariam despesas sem retorno.

Quando não for possível cumprir o plano de ação visando cumprir os objetivos e metas ambientais, como resultado de dificuldades orçamentárias, deverá ser realizada uma análise crítica desse fato pela alta administração, onde sejam explicitadas essas limitações, registradas as justificativas e propostas ações mitigadoras.

É importante que sejam elaborados os procedimentos que possam orientar a forma de acompanhamento dos dispêndios e de análise dos benefícios obtidos, comparando-se com os custos.

Com relação aos custos, verifica-se que as decisões de projeto influem consideravelmente nos custos finais do projeto, razão pela qual existe um interesse grande da alta administração com relação às decisões tomadas nesta fase. Um projeto divide-se, de forma geral, em "Projeto Básico" e "Projeto de Detalhamento", seguindo-se as demais etapas relativas à construção e colocação em serviço da instalação. Se quisermos aumentar o nível de observação, podemos dividir o projeto básico em "projeto de concepção", onde é estudada a exeqüibilidade da instalação (viabilidade), projeto preliminar (onde são aprofundadas as definições de concepção) e projeto de contrato (onde são preparadas as especificações de aquisição dos equipamentos principais, sendo também prontificadas a especificação técnica final e minuta de contrato com o construtor). Ou seja, em cada fase são aprofundadas as definições da configuração selecionada, sendo "congeladas" algumas decisões e critérios de projeto. Esse "congelamento", feito por alguém com poder de decisão, impede que continuamente sejam feitas alterações de requisitos, que provocam muitos atrasos e aumento de custos.

\subsubsection{Funções, responsabilidades e autoridade}

O representante da Direção deverá nomear uma pessoa para que esta, com responsabilidades e autoridade bem definidas, tenha a atribuição de implantar e gerenciar a execução do sistema de gestão ambiental e o cumprimento dos requisitos da norma ISO 
14.001 (se esta for a norma adotada), relatando à alta direção o andamento do programa e a avaliação de desempenho do sistema de gestão ambiental.

Será importante incluir no organograma a função de gerente ambiental, ou de um outro cargo equivalente, subordinado, de preferência, a a áreas que não tenham envolvimento direto com processos que geram poluição ou à produção de resíduos. Essa pessoa deverá gozar da confiança da alta administração, ter a competência requerida no assunto e ter bom trânsito junto a ela, conhecimento das normas ambientais e bom acesso aos órgãos oficiais de controle, de modo que suas opiniões, idéias e reivindicações sejam levadas em consideração.

O gerente de meio ambiente será o responsável por propor o núcleo do sistema de gerenciamento ambiental e redigir as normas e procedimentos de caráter geral e mais especializado, prestar assessoria às demais áreas da organização no assunto, acompanhar e monitorar o planejamento e implantação do sistema de gestão, analisar os dados resultantes de medidas para fazer o monitoramento de sua implementação, e fazer o contato mais direto com os órgãos oficiais de controle do desempenho ambiental, além de reportar os resultados aos níveis mais altos da organização. Ele deve ser o motivador e animador da equipe envolvida com o assunto ambiental.

Além de ter a responsabilidade mais direta, esse profissional deve atuar como "consultor" para outras áreas da organização, respondendo a questões específicas. Para a solução dos problemas e implementação do Plano, é bastante comum que sejam formados Grupos de Trabalho, sob a condução de uma pessoa da área ambiental, compostos de funcionários das várias áreas, responsáveis por mudanças de processos e também da alta administração (chamado de "representante da administração", com papel relevante no processo). Esses funcionários, oriundos das várias áreas, são chamados de "facilitadores" (à semelhança dos processos de Qualidade Total ou de implementação da ISO 9000) e devem trabalhar em tempo parcial no assunto. É muito importante que seja dado apoio a esses funcionários por seus chefes imediatos (a quem eles representam, efetivamente, nas reuniões de trabalho) e que haja algum tipo de reconhecimento, ao final de cada etapa bem sucedida (elogios, promoções na carreira, prêmios). Os chefes imediatos, ou gerentes, devem definir claramente as responsabilidades do seu pessoal operacional quanto aos aspectos ambientais nas rotinas de trabalho, procedimentos e normas internas. Não deve ser esquecida nesse grupo a participação do representante da área de garantia da qualidade, que irá compatibilizar as ações de qualidade ambiental com aquelas referentes aos sistemas da 
qualidade (ISO 9000). Deve ser considerada a presença de funcionários das áreas de comunicação social (para a necessária divulgação) e de treinamento.

Dessa forma, verifica-se que as responsabilidades de implementação e monitoramento do sistema de gestão ambiental não se limitam ao pessoal do setor ambiental, devendo abranger outros funcionários e várias áreas da empresa.

A organização deverá possuir um sistema de avaliação da qualificação e do desempenho do pessoal que atua em seu Sistema de Gestão Ambiental.

\subsubsection{Recursos humanos: competência, conscientização e treinamentos}

É fundamental que exista na organização uma conscientização adequada quanto à importância da questão ambiental para o sucesso na realização de suas atividades, incluindo metas relacionadas à própria sobrevivência da empresa. Para que seja conseguido um nível satisfatório de conscientização e conhecimento do problema, e do conhecimento da importância do cumprimento da política ambiental e exigências de um sistema de gestão ambiental, deverá ser proporcionado um treinamento formal sobre:

- as funções e responsabilidades de cada um no processo;

- os aspectos e os impactos ambientais resultantes das atividades, reais ou potenciais;

- as penalidades e riscos, com as consequiências do não cumprimento dos procedimentos especificados;

- os beneficios resultantes para a organização e para seus componentes, quando ocorrer um bom desempenho ambiental.

A conscientização ambiental está muito ligada à motivação, ou seja, à vontade que as pessoas têm de realizar seus trabalhos da melhor maneira possível, enquanto o treinamento refere-se a preparar as pessoas para que elas bem desempenhem suas funções. Ou seja, a conscientização diz respeito a "querer fazer" enquanto o treinamento a "saber fazer". De nada adianta um funcionário possuir todo o conhecimento necessário para fazer seu trabalho gerando poucos resíduos se ele não estiver motivado, "querendo" trabalhar daquela forma correta, e da mesma forma, um funcionário que queira fazer da melhor forma (conscientizado em problemas ambientais e motivado), porém não saiba como trabalhar da melhor forma, não saiba como ajustar sua máquina de forma gerar menos resíduos ou evitar vazamentos. 
É importante ressaltar o papel-chave a ser desempenhado pela alta administração na conscientização e motivação dos empregados, mostrando o seu comprometimento com a política ambiental e a importância de um bom desempenho ambiental, de modo a que o sistema de gestão ambiental não fique somente no papel, mas se transforme em realidade.

O treinamento deve ser previsto (e sua realização posteriormente comprovada), para todos os profissionais cujas funções e tarefas tenham a possibilidade de causar impactos ambientais significativos, independentemente de seu nível hierárquico.

As pessoas com envolvimento profissional exclusivo na questão ambiental deverão receber um treinamento mais aprimorado, já que elas irão dar assistência especializada aos outros setores, agindo como os principais motivadores na busca de uma melhoria contínua no desempenho ambiental. Os "facilitadores", por sua vez, deverão receber um treinamento mais reduzido e direcionado às suas áreas de atuação, sendo considerados como transmissores de conhecimento para as suas áreas específicas de trabalho. Neste nível, o treinamento deverá ser mais prático e objetivo, mais limitado, feito na época da real utilização, pois qualquer lapso de tempo implica em esquecimento rápido dos conceitos, ou seja, prejuízos financeiros decorrentes do tempo (neste caso perdido) utilizado em treinamentos, perdas de produção, ou seja, baixo retorno do treinamento.

Deverão ser identificadas as necessidades de treinamento quanto à questão ambiental, referentes às diversas áreas e níveis funcionais. Deverão receber algum tipo de treinamento todas as pessoas que tenham um nível funcional de decisão, quanto à priorização de atividades de melhoria de processos ligados a aspectos ambientais e de recursos financeiros, ou diretamente ligados ao setor ambiental e, principalmente, aqueles funcionários cujas atividades causem impactos sobre o meio ambiente, principalmente se essas atividades forem realizadas de uma forma incorreta.

O treinamento é particularmente importante para os novos funcionários, que devem ser avaliados com relação ao conhecimento na realização de seus trabalhos de forma ambientalmente responsável, principalmente quando a organização já realizou a implantação do SGA e treinou seus próprios funcionários na adoção de práticas corretas. A entrada de novos funcionários não conscientizados e treinados nesses assuntos pode levar à rápida deterioração de todo o sistema, por contaminação. Uma das idéias muito colocada em prática por algumas empresas bastante conceituadas tem sido somente fornecer o crachá definitivo aos novos funcionários (que lhes dá direito a muita facilidades, entrada fácil no refeitório, nos locais de trabalho, por exemplo) somente quando esses funcionários recebem 
algum tipo de treinamento sobre a postura ambiental a ser adotada, a Política Ambiental e as principais práticas de trabalho. $\mathrm{O}$ próprio recrutamento e seleção devem levar em conta estes aspectos.

Deverão ser elaborados procedimentos específicos quanto às necessidades de treinamento, assegurando que todas as pessoas cujas tarefas possam criar um impacto significativo sobre o meio ambiente, recebam um treinamento apropriado. Essas pessoas deverão, com treinamento, se tornarem competentes, por meio da educação formal, de treinamentos específicos e do ganho de experiência, com o tempo.

Os procedimentos deverão enfocar as possibilidades de treinamentos a serem feitos dentro ou fora da organização, bem como a respeito do seu controle, registros de treinamento e verificação da sua eficiência. Por ação da alta gerência, deverão ser reconhecidas as realizações ambientais obtidas pelos funcionários.

A Tabela 3.3 apresenta algumas sugestões de treinamento.

Tabela 3.3 - Treinamentos recomendados (Sugestões e exemplos):

\begin{tabular}{lll}
\hline Nível Funcional & \multicolumn{1}{c}{ Treinamento } & Objetivos do Treinamento \\
\hline Direção & - Importância estratégica da gestão & - Determinação da política \\
& ambiental & ambiental \\
& - Análise das vantagens para a & - Obter o comprometimento \\
& organização & da alta direção (quebrar o \\
& - Custos envolvidos & ceticismo, originário de \\
& & experiências anteriores \\
& & desfavoráveis) \\
Funcionários da & & - Aumentar o conhecimento \\
área de gestão & & do problema com vistas à \\
ambiental & - Sistemas de Gestão Ambiental & atribuição de prioridades e de \\
& - Ciência ambiental e sistemas da & recursos \\
& planta (associados a aspectos & operacionalização do SGA \\
& ambientais) & - Solução de problemas \\
& - Conhecimentos de requisitos legais & ambientais da organização \\
& e normas ambientais & procedimação de \\
& - Auditoria ambiental & trabalho instruções de \\
& - Análises de riscos & - Formação de auditores \\
& - FMEA e análises de risco dos & ambientais internos \\
& sistemas & - Melhoramento contínuo de \\
& & métodos \\
\hline
\end{tabular}


Tabela 3.3 - Treinamentos recomendados (Sugestões e exemplos). Conclusão

\begin{tabular}{|c|c|c|}
\hline Nível Funcional & Treinamento & Objetivos do Treinamento \\
\hline $\begin{array}{l}\text { Gerentes, } \\
\text { Executivos e } \\
\text { Encarregados de } \\
\text { Processos, } \\
\text { Engenharia, } \\
\text { Planejamento, } \\
\text { Compras. }\end{array}$ & $\begin{array}{l}\text { - Conhecimentos básicos sobre a } \\
\text { questão ambiental } \\
\text { - Sistemas de gestão ambiental } \\
\text { - Identificação dos aspectos e } \\
\text { impactos ambientais } \\
\text { - Qualidade total e gestão ambiental } \\
\text { - Inventários de poluentes e resíduos } \\
\text { - Análise dos sistemas da planta } \\
\text { industrial e seus impactos sobre o } \\
\text { meio ambiente } \\
\text { - Legislação ambiental e seus } \\
\text { impactos para a organização } \\
\text { - Ações em emergências com riscos } \\
\text { ambientais }\end{array}$ & $\begin{array}{l}\text { - Implantação e } \\
\text { operacionalização do SGA } \\
\text { - Conhecimento da política. } \\
\text { - Definição(em grupos de } \\
\text { trabalho designados) dos } \\
\text { objetivos e metas } \\
\text { - Solução de problemas } \\
\text { ambientais da organização } \\
\text { - Preparação de } \\
\text { procedimentos e instruções } \\
\text { de trabalho } \\
\text { - Melhoramento contínuo } \\
\text { de métodos } \\
\text { - Formação de auditores } \\
\text { ambientais internos } \\
\text { - Orientação ao pessoal sob } \\
\text { sua responsabilidade }\end{array}$ \\
\hline $\begin{array}{l}\text { Pessoal } \\
\text { operacional } \\
\text { (sobretudo os que } \\
\text { têm relação com o } \\
\text { cumprimento de } \\
\text { conformidades) }\end{array}$ & $\begin{array}{l}\text { - Conscientização no assunto } \\
\text { (conhecimentos básicos sobre a } \\
\text { questão ambiental) } \\
\text { - Treinamento específico em } \\
\text { processos (relacionados a aspectos } \\
\text { ambientais) } \\
\text { - Inventários de poluentes e resíduos } \\
\text { - Técnicas de medição de variáveis } \\
\text { ambientais } \\
\text { - Soluções para economia de energia } \\
\text { e de matéria prima } \\
\text { - Treinamento específico quanto ao } \\
\text { cumprimento de normas e leis } \\
\text { - Aferição e calibração de } \\
\text { instrumentos } \\
\text { - Treinamentos específicos em } \\
\text { sistemas de emergência } \\
\text { - Manuseio de produtos perigosos. }\end{array}$ & $\begin{array}{l}\text { - Ampliação da } \\
\text { conscientização e do senso de } \\
\text { responsabilidade } \\
\text { - Conhecimento e } \\
\text { compreensão da política } \\
\text { ambiental } \\
\text { - Cooperação na identificação } \\
\text { dos aspectos e impactos } \\
\text { ambientais relacionados aos } \\
\text { processos industriais } \\
\text { - Conhecimentos com vistas a } \\
\text { cumprir os objetivos e metas }\end{array}$ \\
\hline
\end{tabular}

Deverá ser realizado um controle simples, porém eficiente, para comprovar junto aos auditores, a efetiva realização dos treinamentos. Desta forma, além de outros registros, sugere-se que o setor de treinamento abra uma ficha para cada funcionário, inserindo-se informações como as indicadas na Tabela 3.4, por exemplo. 
Tabela 3.4 - Ficha de registro de treinamentos

\begin{tabular}{|c|c|c|c|c|c|c|}
\hline \multicolumn{6}{|c|}{ FICHA DE CONTROLE DE TREINAMENTO } & \multirow{2}{*}{$\begin{array}{l}\text { Referência: } \\
\text { ISO 14001 } \\
\text { Item } 4.4 .2 \\
\text { A.4.2 } \\
\end{array}$} \\
\hline \multicolumn{3}{|c|}{ Funcionário: } & \multicolumn{2}{|l|}{ Crachá: } & Setor: & \\
\hline Nome do curso & Data & $\begin{array}{l}\text { Carga } \\
\text { horária }\end{array}$ & $\begin{array}{l}\text { Aprovação } \\
\operatorname{Sim} / \text { Não }\end{array}$ & $\begin{array}{l}\text { Nota de } \\
\text { aprovação }\end{array}$ & $\begin{array}{l}\text { Nome do } \\
\text { instrutor }\end{array}$ & $\begin{array}{l}\text { Rubrica do } \\
\text { instrutor }\end{array}$ \\
\hline & & & & & & \\
\hline & & & & & & \\
\hline
\end{tabular}

A preparação do treinamento deverá levar em conta os hábitos e costumes da organização, contando-se com as seguintes possibilidades:

- treinamento em sala de aula, ou em escolas (adquirir conhecimentos técnicos, para depois aplicar em problemas práticos);

- treinamento "on the job" pelos supervisores, este sendo um dos melhores métodos;

- auto-treinamento por manuais e documentos escritos (principalmente para nível superior e alta gerência);

- cursos de treinamento na própria organização ;

- cursos com a colaboração de Universidades, Escolas Técnicas e Consultorias.

Para os funcionários de nível mais elevado, uma boa forma de aprender e conhecer bem a situação ambiental da empresa é acompanhar os trabalhos de uma auditoria ambiental, analisando cada resposta da lista de questões respondida por cada setor auditado.

As experiências de treinamentos de funcionários da alta gerência indicam algumas dificuldades que devem ser conhecidas para serem superadas, resultando em treinamentos eficientes. Em primeiro lugar, será necessário vencer o descrédito com o treinamento, pois é comum a crença de que já se conhece bem o problema e o treinamento é uma perda de tempo e de dinheiro, e que somente deva ser feito para "os outros" (operários, engenheiros, média gerência). Somente uma atmosfera de crise colabora para mudar esse modo de pensar. Lembra-se que, na implantação do SGA, o ideal é que o treinamento seja iniciado pela alta gerência, para obtenção de apoio.

No nível operacional, considera-se que a formação "on the job" e outros treinamentos (como em salas de aula) constituem uma responsabilidade do supervisor. $O$ 
operário deve estudar os procedimentos e outros documentos antes de iniciar o trabalho, e o supervisor deve orientá-lo (aprendizado por indução); constitui-se em uma boa prática realizar uma rotação entre os postos, para que o operário fique com um conhecimento mais completo.

Para que haja eficiência no processo de treinamento, lembra-se que os alunos não devem ir para cursos onde eles já estão super-qualificados ou sub-qualificados.

O treinamento é um trabalho profissional que deve ser bem preparado, como qualquer outro trabalho da organização. Assim sendo, devem ser providenciados todos os recursos materiais e humanos necessários, tanto relativos à apresentação da matéria (projetor, transparências, filmes, ambiente silencioso e com temperatura adequada) bem como prevendo um bom material didático, para que o treinando possa, após a aulas, consolidar os conhecimentos apresentados em salas de aulas.

A auto-instrução, por manuais ou livros também pode ser realizada, ou complementada, pelos seguintes recursos:

- aulas gravadas: usualmente suplementadas por um livro. O mais interessante é assistir em grupos, para que seja fomentada uma discussão sobre o assunto;

- filmes de treinamento: por exemplo, que apresentem sistemas e técnicas gerenciais de gestão ambiental, métodos estatísticos e confiabilidade;

- instrução programada: o aluno recebe um manual e vai prosseguindo os estudos de forma isolada, realizando testes durante todo o tempo. Se as respostas não forem corretas, haverá indicações de retorno, para repetir o aprendizado, Dessa forma, o próprio estudante julga a absorção que está conseguindo obter, durante todo o treinamento.

Outras formas de complementação à instrução formal são:

- estudo detalhado e orientado do Manual do SGA, pois este documento apresenta um resumo didático com uma visão geral do assunto na organização, além de citar e direcionar o leitor para outras instruções e procedimentos;

- visitas a empresas, sobretudo a fornecedores;

- participação em eventos como congressos, simpósios, seminários e cursos;

- obtenção de publicações especializadas, tais como livros, artigos de jornais que registram casos e experiências.

As seguintes perguntas precisam ser respondidas, ao ser preparado um programa de treinamento ( $5 \mathrm{~W} 1 \mathrm{H}$ com pequenas adaptações):

- quem deverá ser treinado (Who)?

- por que deverá ser treinado, treinamento em que (Why)? 
- quanto tempo vai durar o treinamento? Quando se inicia, quando termina (When)?

- onde será feito o treinamento, na própria empresa ou fora? Onde será obtido o material de treinamento (Where)?

- quais são as prioridades, objetivos e metas? Definir aquilo que vai ser feito (What).

- como será feito o treinamento (How)?

- quanto vai custar o treinamento (How much)?

A maioria dos funcionários acredita que já está fazendo o seu trabalho corretamente. Ao se preparar o treinamento, é necessário responder à seguinte pergunta "O que é que você quer que eu faça de forma diferente do que eu estou fazendo, e o que isso vai resultar em melhoria"?

Para realizar com sucesso um programa de treinamento, é interessante analisar as principais causas de insucesso, visando evitá-las. Segundo Juran (1988), as principais causas são:

1) Resistência cultural dos gerentes. Juran avalia que uma grande parte dos gerentes acredita que, tanto eles próprios quanto as pessoas de seu grupo, já conhecem bem o problema, possuem todas as informações necessárias e que, portanto, não há a necessidade de treinamento adicional, considerado uma perda de tempo. Para corrigir essa falha, a solução mais indicada é obter o apoio da alta administração, começando o treinamento a partir dos níveis mais altos. Neste caso, os gerentes irão, provavelmente, mostrar um maior envolvimento.

2) Dúvidas sobre a utilidade do treinamento. A solução é procurar exemplos de não-conformidades e problemas dentro da própria empresa, citando-os.

3) Falta de participação dos gerentes. Associado ao item 1, os gerentes acham que as horas dispendidas pelos funcionários em treinamento são horas perdidas de produção. A solução é envolver alguns gerentes nas equipes de treinamento.

4) Mistura de níveis hierárquicos em um mesmo grupo. Essa mistura pode inibir as discussões e a formulação de dúvidas. A solução é formar grupos homogêneos.

5) Falta de aplicação prática durante o curso. Cursos teóricos e somente conceituais podem ser aplicados nos níveis mais altos, onde não haja muito tempo disponivel para aplicações práticas. Em todos os outros niveis devem ser previstas aplicações práticas, preferencialmente com exemplos e projetos da própria empresa, 
concebidos para o curso. O TQC e Círculos da Qualidade são fortemente apoiados por exemplos práticos, a partir de uma identificação dos maiores problemas da área em estudo.

6) Inadequação dos instrutores. Os instrutores precisam demonstrar credibilidade profissional, além de serem bons professores, que utilizem técnicas de ensino apropriadas.

7) Linguagem muito complexa. A linguagem e conceitos empregados devem ser adequados à audiência. Por exemplo, termos de estatística são bastante simples para aqueles que os conhecem e inacessiveis para os outros. A solução para isso é prever uma preparação cuidadosa, com realimentação por parte dos alunos.

8) Deficiências logísticas e operacionais. Ruído excessivo no local de treinamento, calor, falta de recursos de apoio, como equipamentos multimídia e outros, falta de um cafezinho nos intervalos, por exemplo.

\subsubsection{Comunicações}

Os sistemas de gestão ambiental definem que as organizações estabeleçam e mantenham procedimentos para:

- a comunicação interna entre os vários níveis e funções da organização (por exemplo, em relação ao planejamento, o monitoramento do SGA, resultados de auditorias, divulgação das metas e resultados alcançados);

- o recebimento, documentação e resposta às comunicações pertinentes das partes interessadas externas (identificar suas principais preocupações, demonstrar o funcionamento do SGA, o desempenho ambiental atingido).

Um cuidado especial deverá ser tomado em relação às comunicações com as autoridades públicas para planejar as ações requeridas em situações de emergência e outras questões relevantes.

O grande objetivo das comunicações consiste em motivar os empregados, divulgar as ações da administração, definir o fluxo interno de informações e documentos e melhorar o relacionamento com a comunidade. As comunicą̧ões, especialmente as próativas (ou seja, aquelas feitas sem demanda, sem nenhum pedido pelas partes interessadas), colaboram para aumentar a confiança na organização, permitindo que sejam explicitados e reconhecidos os seus esforços na melhoria de seus sistemas e procedimentos.

É necessário estabelecer um sistema de tratamento das perguntas das partes interessadas, ou seja, gerar normas que definam as responsabilidades e orientações sobre como responder, arquivar e controlar o assunto. Os procedimentos devem definir 
formalmente o nível de comunicação pró-ativa, que deve ser implementado, ou seja, estabelecer o que deve ser comunicado, e a quem.

Como sugestão, os relatórios que forem preparados para divulgação pública, com o objetivo de demonstrar que a organização busca uma melhoria de desempenho ambiental, devem, em princípio, conter:

- dados gerais sobre a organização (organogramas, objetivos, resultados);

- a política ambiental;

- os principais objetivos e metas ambientais em linguagem compreensível (não muito técnica);

- os principais programas de gestão ambiental;

- as metas e intenções de melhoramento contínuo;

- uma descrição simplificada dos processos industriais, aspectos e impactos ambientais (sem violar sigilos industriais);

- uma declaração e demonstração do cumprimento de requisitos legais, normas corporativas e normas ambientais próprias (por exemplo, um quadro registrando os limites legais máximos de emissões e os valores reais medidos em um certo período de tempo especificado);

- dados sobre conservação de recursos (água, energia e matéria prima).

As informações devem ser transmitidas em linguagem simples, acessível e de fácil compreensão pelos interessados.

As formas de comunicação mais comuns são:

- com o público externo: boletins, relatórios anuais, folhetos explicativos (folders) página na Internet, anúncios pagos em jornais, divulgação de um telefone para consultas e reclamações, reuniões e outros eventos abertos ao público;

- com o público interno: boletins, quadros-murais, reuniões, mensagens pelo correio eletrônico, jornais internos, intranet, folhetos;

- do público com a organização: reuniões, cartas, e-mails e telefonemas.

As informações prestadas pela organização devem ser comprováveis, ou seja, se for solicitado algum esclarecimento adicional, ela precisa estar preparada para mostrar seus registros com dados, permitir visitas guiadas às instalações, entre outras ações, para comprovar a veracidade daquilo que foi informado, sem que ocorra violação de sigilo tecnológico ou industrial.

É necessário que os responsáveis pelas comunicações conheçam o papel dos jornalistas, que é diferente do papel de cientistas. Muitos jornalistas tendem a ser 
individualistas e estão interessados em assuntos que vendam noticias, mais do que educar o público, como muitos cientistas esperam que deveria ocorrer, e nem sempre são atendidos. Os jornalistas trabalham sob intensa pressão do tempo, e competição para que o seu material seja incluído nos veículos de comunicação. Os cientistas, por sua vez, não são sujeitos a prazos tão estritos, e tendem a ser mais precisos. Portanto, quando houver a necessidade de interação de representantes da organização com a imprensa, é necessário um maior cuidado no tocante à solicitação de precisão, pois a área nuclear já vê, em boa parte do público, uma predisposição negativa, principalmente quanto à questão dos riscos.

A organização deve manter um arquivo com cópia de todas as comunicações realizadas (registro dos documentos recebidos e emitidos).

Um tópico essencial no tocante às comunicações refere-se à divulgação das situações de risco, que são informações de elevado interesse, principalmente para as comunidades vizinhas e os órgãos ambientais. Constata-se que é necessário muito cuidado com a terminologia empregada (recomenda-se que não seja muito técnica) e com a forma de expor o assunto.

Passaremos a apresentar, de forma resumida, alguns aspectos relacionados com a percepção (como as pessoas em geral percebem e se posicionam frente aos riscos) e com a comunicação dos riscos.

A avaliação de riscos tem por objetivo auxiliar a tomada de decisão com relação à implantação de empreendimentos. Uma das atividades importantes é a de "comunicação dos riscos", o que é bastante difícil, pois o público usualmente não dispõe de formação ou informações suficientes para avaliar corretamente o risco real existente.

O risco real é, quase sempre, diferente do risco imaginado ou percebido pelo público, ou partes interessadas, excetuando-se os especialistas dos órgãos ambientais (se estes forem considerados como "público", embora sejam tomadores de decisão e também se preocupem em como a sociedade vê e reage aos riscos). Se considerarmos como público a comunidade próxima ao empreendimento, os formadores de opinião, a imprensa, as ONGs e outros, verificamos que, em função de experiências anteriores, comportamentos, informações disponiveis e outros fatores subjetivos, a percepção que eles têm do risco pode ser falsa ou distorcida, subestimada ou superestimada, resultando em desvios em relação ao risco real existente. Normalmente são superestimados os riscos de vazamentos em indústrias químicas e de acidentes nucleares.

Um dos problemas da organização é, portanto, procurar fazer com que os riscos de seu empreendimento possam ser percebidos pelo público de uma maneira realista e seja 
explicada com argumentos técnicos, usando-se comparações, de modo que as resistências irracionais sejam contornadas. A comunicação de riscos é um processo interativo de troca de informações e opiniões entre indivíduos, grupos e instituições, ficando claro o caráter de mão dupla de troca de informações para a solução de tensões. Existem dúvidas sobre a eficácia de comunicados publicados pela imprensa como matéria paga, preferindo-se outras formas de comunicação como palestras, debates, artigos que permitem análise e resposta. A melhor abordagem técnica para convencimento do público normalmente consiste em relacionar a probabilidade de ocorrência do evento (muito baixa) com a conseqüência resultante.

Uma análise interessante consiste em comparar o risco objetivo com o risco subjetivo (avaliado). O risco objetivo é aquele baseado em cálculos matemáticos $\mathrm{e}$ estatísticos. O risco subjetivo é aquele baseado em julgamentos intuitivos das pessoas. Em muitos casos, a percepção do risco pode resultar em situações desconfortáveis ou de stress. Por exemplo, quando ocorreu em 1987 o acidente radioativo em Goiânia (abertura indevida de uma cápsula de césio), assim que foi noticiado o acidente, cerca de 5.000 pessoas procuraram os serviços de saúde, alegando, ou realmente apresentando sintomas de stress $\mathrm{e}$ alergias, quando nenhuma delas apresentava alguma contaminação.

\subsubsection{Sistema de documentação}

O objetivo da documentação é descrever os principais elementos do SGA, ou seja, registrar a política ambiental, objetivos, metas, programas, funções-chave e definição de responsabilidades. Os principais documentos relacionados a este assunto são o Manual de Gestão, os Procedimentos e as Instruções de Trabalho. É interessante que a documentação do SGA siga os padrões de documentos da organização, principalmente para facilitar a integração do sistema à administração e à política global.

É mais comum existirem tais documentos em papel, porém é cada vez mais crescente o uso de arquivos eletrônicos em computadores $\mathrm{PC}$, pelas inúmeras vantagens e economia. Entretanto, é necessário aumentar o nivel de controle sobre a atualização destes arquivos, sob risco de uso de documentos que já perderam validade e foram substituídos, bem como existir um bom controle de back-ups. Há uma tendência atual de que a documentação técnica das organizações passe a ser feita em arquivos eletrônicos, on line, para acesso por todos os interessados, em sistemas denominados EDMS (Electronic Data Management Systems). 
A documentação escrita constitui a maior fonte de informações para as auditorias.

Além de procedimentos específicos para os processos, há também necessidade de existirem procedimentos para controle dos próprios documentos previstos.

Os procedimentos e instruções de trabalho visam evitar a improvisação, que é uma fonte enorme de problemas e causa de grandes desperdícios, pois quase sempre as atividades não serão cumpridas da forma mais correta e eficaz, quando improvisadas. Ao se criar um procedimento, prevendo com antecedência e de forma bem pensada as ações a realizar, os resultados serão melhores, disseminando as boas práticas em toda a organização.

Deverá ser previsto um controle adequado dos documentos do sistema de gestão ambiental. Cada documento deve ser único, completamente legivel, escrito em linguagem clara e simples. Além disso, devem ser observados os seguintes aspectos:

- codificação (de modo a permitir fácil recuperação, usar de preferência o sistema WBS - Work Breakdown Structure, em que o empreendimento é "quebrado" em sistemas, com um sistema numérico ou alfanumérico que identifique os sistemas e seus elementos constituintes, equipamentos e acessórios);

- localização rápida, principalmente no decorrer de uma auditoria. É interessante que a edição original (matriz) dos documentos fique em um arquivo técnico central da organização;

- revisão quando necessário (controle de revisões);

- informações sobre as datas de aprovações e as datas de revisões;

- identificação clara de autores e revisores (nome legível ou rubrica, desde que exista um fichário de rubricas);

- aprovação por um gerente responsável (controle de autorizações para aprovar documentos);

- disponibilidade da versão atualizada em locais adequados (onde necessário, ou seja, onde sejam realizadas as operações que geram impactos e que exigem controle);

- remoção dos documentos obsoletos (e sua destruição ou arquivamento);

- existência de arquivos com cópias de segurança (para uso em caso de incêndio e outros eventos), e back-ups de arquivos eletrônicos;

- preservação de alguns documentos (identificando-os claramente) para fins legais.

Os tipos de documentos mais utilizados são: 
- manual de gestão ambiental;

- procedimentos sistêmicos;

- procedimentos operacionais;

- instruções de trabalho;

- rotinas operacionais.

Os documentos devem incluir:

- descritivo sumário e finalidade da organização (missão);

- a Política Ambiental;

- organogramas (com destaque para o posicionamento da área ambiental);

- definições das funções e responsabilidades;

- informações sobre os processos;

- padrões internos e procedimentos operacionais;

- padrões para registros;

- planos de emergência.

Devem ser implantados procedimentos para:

- indicar ações aos operadores de modo a evitar desvios que possam causar problemas ambientais;

- ações para os empreiteiros;

- monitoramento do processo;

- procedimentos para a contratação de pessoas e serviços;

- gerenciamento de registros, com registros de:

- requisitos legais;

- regulamentos;

- aspectos e impactos ambientais (emissões);

- controle de matérias primas;

- multas e infrações;

- acidentes e incidentes;

- consumos de recursos (água, energia, outros recursos);

- calibração e aferição de instrumentos de medidas;

- comunicação com partes interessadas (queixas, elogios);

- desempenho dos fornecedores;

- desempenho dos sub-contratados; 
- resultados de auditorias ambientais.

Os procedimentos relacionados às atividades principais do SGA, incluindo o registro das atividades causadoras dos impactos ambientais mais significativos, devem ser feitos por escrito (existência formal). Além de melhor consolidar os conceitos e registrar as obrigações dos funcionários, tais documentos constituem-se em uma excelente ferramenta de padronização das atividades e de processos de treinamento. Entretanto, para fins de certificação, quando a norma não se referir explicitamente a "procedimentos documentados", poderão ser aceitos procedimentos não documentados, vindos de usos e costumes, desde que fique evidenciada uma prática correta das ações implantadas e mantidas, bastante disseminadas na organização.

É desejável que exista um sistema simples, de fácil uso, e não complexo e trabalhoso. A existência do sistema de documentação auxilia, dessa forma, a formalização da responsabilidade das pessoas.

\subsubsection{Controle operacional}

Os controles devem ser concebidos para assegurar que os níveis de desempenho ambiental estejam de acordo com a política, objetivos e metas, ou seja, devem permitir uma verificação constante do cumprimento dos requisitos e metas estabelecidos.

A organização deverá, segundo a norma ISO 14.001 (ABNT, 2004), identificar as operações e atividades associadas aos aspectos ambientais significativos, para que seja dada uma maior atenção a essas atividades, sendo essas operações contidas no escopo do controle operacional.

$\mathrm{Na}$ falta de controles, poderiam ocorrer desvios em relação aos objetivos e metas ambientais, ou da própria política ambiental. Os procedimentos e requisitos que devem ser cumpridos pelos fornecedores e prestadores de serviços devem ser comunicados a estes participantes (importantes) do processo de melhoria de desempenho ambiental.

Para efetivar o controle, sugere-se elaborar listas de verificação (check lists), para orientar o monitoramento constante das características importantes dos processos, observando se as atuações são feitas sobre as causas e não sobre os efeitos. Os poluentes, em muitos casos, são emitidos de forma anormal como resultado de operações indevidas de máquinas, perdas de produtos, estocagem inadequada, entre outros fatores. Assim, os controles devem ser voltados às atividades de prevenção (prevenir a poluição) e conservação de recursos. As técnicas para controle de poluição (ou minimização de seus efeitos) devem ser bem conhecidas pelos gerentes e operadores dos processos industriais. 
Os controles estão, muitas vezes, relacionados à operação apropriada dos equipamentos, devendo-se assegurar:

- um elevado grau de disponibilidade e confiabilidade das máquinas, obtido por meio de um eficiente trabalho de manutenção;

- a realização de inspeções periódicas e rondas de verificação de segurança;

- a realização de treinamento dos funcionários, assegurando-se a operação correta dos equipamentos, bem como das ações a serem tomadas em situações de emergência;

- o registro e avaliação sistemática das interrupções ocorridas, referentes a acidentes e incidentes;

- a implementação das ações de proteção na utilização de materiais perigosos, como, por exemplo, instruções de operação de equipamentos e manuseio de material, uso de equipamentos de segurança e outras medidas de proteção.

\subsubsection{Preparação e resposta a emergências}

A organização deve estabelecer e manter procedimentos para indicar as ações a serem tomadas em acidentes e situações de emergência, bem como para prevenir e mitigar os impactos ambientais associados. Esses procedimentos devem ser revistos e atualizados, principalmente após uma eventual e indesejável ocorrência de acidentes, incorporando-se a experiência prática duramente obtida.

Em resumo, esses procedimentos devem detalhar as responsabilidades das pessoas e prever o material requerido para dar cobertura rápida às ações emergenciais, de forma a reduzir as conseqüências do acidente. Uma outra grande vantagem associada é que, ao serem preparados, obrigam a uma maior reflexão, aumentando o nível de conhecimento do problema. Dessa forma, as situações de risco ficam mais visíveis e permitirão a identificação de medidas que conduzam a modificações nos processos, instalações de dispositivos de segurança e um melhor treinamento dos operadores. Sempre que possível, devem ser aplicados os procedimentos em simulações e exercícios práticos (por exemplo, em mock-ups de exercícios contra incêndios).

Nota-se que, recentemente, em alguns acidentes em empresas com grandes repercussões ambientais, tem sido muito criticada a falta de Planos de Contingência, ou Planos de Resposta a Emergência, que preparam a organização para essas situações, indicando as ações a tomar na eventualidade do acidente. Mesmo pequenos vazamentos, cujas conseqüências sejam avaliadas como causadoras de impactos significativos, devem 
ser objeto de cuidados maiores, sendo previstas ações de preparação e resposta a essas emergências. Os planos deverão apresentar os procedimentos necessários, prevendo ações como o acionamento do plano, avaliação da situação, controle, rescaldo, descontaminação da área e assistência a eventuais vítimas. Deverão ser identificadas as possíveis emissões acidentais para a atmosfera, as emissões para as águas e as descargas em potencial para o solo, bem como as consequiências dessas emissões sobre o meio ambiente e os ecossistemas. Com essa análise, ficarão evidenciadas as emergências potenciais.

Sempre que possível, devem ser realizados testes com os sistemas previstos para atuar em situações de emergência (por exemplo, ativar periodicamente o sistema de combate a incêndios). Em situações onde não seja possível realizar os testes, será necessário buscar outros mecanismos para assegurar a disponibilidade e efetividade dos sistemas de segurança, por meio de simulações e realizando-se um planejamento bem elaborado, contemplando todas as possibilidades e situações.

Para controlar as situações de emergência, os procedimentos devem enfocar:

- identificação e caracterização de todos os possiveis cenários de acidentes, estudando-se as áreas de risco e processos críticos e sua classificação; dar ênfase na identificação dos riscos à saúde e segurança dos trabalhadores e do público externo;

- caracterização dos possíveis impactos ambientais resultantes dos diferentes cenários de acidentes;

- definição das responsabilidades de cada operador envolvido ou coordenador da ação; descrição da estrutura organizacional e funcional do controle de emergências (eventualmente para cada cenário acidental);

- mecanismos para localização e convocação rápida de pessoas-chave (telefone celular, BIPs, lista com telefones residenciais das pessoas);

- identificação dos equipamentos e materiais adequados para a resposta às emergências (para a monitoração, apoio a ações visando interromper o acidente, descontaminação e assistência a eventuais vítimas), providências para a sua aquisição, treinamentos no uso, ações visando sua correta manutenção e garantia de disponibilidade;

- lista de ações a serem rapidamente tomadas pela equipe, para cada tipo de acidente;

- preparação de Fichas de Emergência para os materiais perigosos envolvidos nos processos;

- procedimento para convocação rápida do Corpo de Bombeiros e de empresas especializadas, se for o caso; 
- descrição dos programas de treinamento das equipes de atendimento a emergências, tais como cursos, aulas teóricas sobre os perigos, tipo e justificativa de cada uma das ações, como isolamento, e evacuação de áreas sob risco, ações de resgate de vítimas, de combate aos eventos anormais (fogo, vazamentos, explosão), treinamento prático em simulador;

- recursos de alarmes e sinalização do acidente;

- procedimentos indicando ações a tomar na ocorrência das emissões acidentais para a atmosfera, para as águas (rios, lagos, córregos, rede de esgoto) ou vazamentos para o solo;

- recursos e procedimentos para o monitoramento ambiental após o acidente;

- introdução de mecanismos que aumentem a segurança (válvulas de alívio, redundâncias, tanques de transbordo, bacias de contenção);

- realização de análises de risco, HAZOP, modelos de vulnerabilidade da planta;

- plano de comunicações internas e externas (vizinhos, outros representantes da comunidade);

- preparação de informações sobre os materiais perigosos existentes, o impacto desses materiais sobre pessoas e sobre o meio ambiente, medidas corretivas imediatas (primeiros socorros para pessoal e ações para mitigar os impactos);

- procedimentos para comprovar as ações do operador na situação de funcionamento anormal das máquinas e sistemas;

- procedimentos para retomada das atividades, após a solução dos problemas;

- procedimento para preservação de segredos industriais, nas situações de emergência;

- planos de treinamento para verificar a efetividade das ações e o grau de prontidão das equipes.

Muitas situações de emergência com repercussões ambientais ocorrem durante operações de transporte de produtos, principalmente combustíveis e outros produtos químicos. Cuidados especiais devem ser tomados (sendo definidos procedimentos específicos) em situações de transferência de cargas e interconexão entre diferentes meios de transporte (transporte intermodal). Dependendo dos riscos envolvidos com o produto, devem ser estudados os itinerários, as condições de manutenção das rodovias, os pontos de apoio, as épocas do ano mais adequadas, os riscos de alagamentos em épocas de grandes chuvas, a sazonalidade de tráfego (feriados e safras agrícolas), o apoio possível de órgãos 
de defesa civil e do Corpo de Bombeiros. Sendo possível e economicamente viável, devem ser escolhidas as rotas de menor risco, evitando-se áreas densamente povoadas, áreas de proteção de mananciais e de reservatórios de água para a população. Devem ser identificados os pontos vulneráveis do percurso, tais como cruzamento com outras rodovias ou ferrovias. Se necessário ou recomendável, deve ser previsto comboio com escolta. Os veículos deverão estar sinalizados, com simbologia de acordo com o produto transportado, de acordo com os Decretos Federais $n^{0} 88.821$ de 06/10/83 (aprova o Regulamento para a Execução do Serviço de Transporte Rodoviário de Cargas ou Produtos Perigosos) e $\mathrm{n}^{\circ}$ 96.044, de 18 de maio de 1988 (aprova o Regulamento para o Transporte Rodoviário de Produtos Perigosos e dá outras providências).

Após uma ocorrência indesejável, deverão ser revistos os procedimentos e o Plano de Resposta às Emergências, em face dos resultados reais.

\subsubsection{A cultura de segurança}

O termo cultura de segurança, cada vez mais empregado pelas indústrias com potencial mais elevado de riscos, foi empregado inicialmente pela Agência Internacional de Energia Atômica, reconhecendo o fato de que a segurança nuclear depende muito das ações e da conscientização das pessoas dentro da organização. Edgar Schein, citado por PACKER (2002), que estudou em profundidade esse problema, propôs três níveis da cultura de segurança na organização.

$1^{\circ}$ nível - Chamou de implementação de "artefatos" - que é a estrutura organizacional visível de processos - aquilo que você consegue ver, ouvir, sentir.

$2^{\circ}$ nível - Chamou de "valores esposados" ou "valores admitidos" - que são as estratégias, metas, filosofias. Trata-se daquilo que a organização diz a respeito dela própria.

$3^{\circ}$ nível - São as "hipóteses básicas ou essenciais", as funções e posturas, que normalmente são inconscientes, as crenças e percepções, os modos de pensar.

Os "artefatos", aquilo que é visível, são os produtos da organização, são as defesas na cultura de segurança, as ações que realmente são tomadas para permitir a realização de uma determinada operação de forma segura, incluindo, por exemplo, procedimentos atualizados, procedimentos conservativos, comunicação aberta, autoverificações, linhas claras de autoridade, auditorias, melhoria de processos, ou seja, as defesas que existem para salvaguardar e prevenir os riscos nucleares.

Os valores esposados, aqui com o termo empregado no sentido de "casados", referem-se aos compromissos assumidos pela direção da organização, aquilo que a 
organização diz que ela quer ser e como deve agir. A sua divulgação é feita por meio da fixação de uma "Política de Segurança", para promover comportamentos, atitudes, expectativas, definições da missão, sendo essencial a sua divulgação e compreensão correta em todos os níveis, feita pela intranet, posters, banners, crachás e documentos divulgados.

É importante que os padrões e critérios relacionados à cultura de segurança, estabelecidos por organismos como a Agência Internacional de Energia Atômica, se transformem em valores esposados pela organização. E, trabalhados para customizá-los à estrutura e hábitos, eles podem ser transformados em procedimentos e instruções de trabalho, ou seja, em "artefatos".

O terceiro nível citado, que consideramos o mais importante a ser atingido, com o auxílio dos valores esposados e dos "artefatos", referem-se às crenças inconscientes que se tornam visíveis pelas ações dos colaboradores, observando-se os padrões de comportamento, que sejam visíveis.

$\mathrm{Na}$ área nuclear, é essencial se buscar a operação segura. Ou seja, estudar os processos envolvidos com ênfase na sua vulnerabilidade e potencial de perigos. A questão de segurança deve ser uma prioridade constante, sendo observadas as vulnerabilidades. A melhor forma para reduzi-las consiste no emprego do princípio da defesa em profundidade, para compensar falhas humanas e falhas materiais. São estabelecidos vários níveis de proteção, na forma de barreiras sucessivas, de modo a impedir a liberação de material radioativo para o ambiente.

Ou seja, é necessária a defesa em profundidade para manter níveis adequados de segurança. Todas as defesas podem ser separadas em um dos três tipos que poderíamos chamar 3 Ps - Planta, Processo e Pessoas:

a) na planta - considera-se que a instalação (planta) é uma barreira efetiva de segurança se ela estiver nas condições de projeto, ou seja, na configuração correta para a qual foi projetada;

b) no processo - devem ser buscadas todas as formas de impedir a propagação de eventuais acidentes;

c) nas pessoas - as barreiras são efetivas se as pessoas tiverem sido treinadas e qualificadas, sendo importante realizar avaliações de desempenho e realimentação dos resultados.

Como exemplo, podemos considerar seis barreiras físicas ou materiais em relação a um combustível nuclear dentro de um reator: a primeira barreira é a própria 
matriz cerâmica, a segunda é a tubulação das varetas, a terceira o vaso do reator, a quarta a blindagem do reator, a quinta sendo a piscina do prédio e a sexta, a contenção do prédio.

Em qualquer organização onde se utilizam processos ou materiais com nível de risco mais elevado que o normal, é muito importante a ênfase em se desenvolver uma cultura de segurança. E, nesse trabalho de organização e gerenciamento da promoção da cultura de segurança, o papel da liderança é vital para a formação dessa cultura em todo o pessoal envolvido. É importante a existência de uma Política de Segurança, emitida pela Alta Administração, com a visão e intenções quanto a este assunto. As atividades do líder devem ser os primeiros exemplos de postura correta frente aos riscos.

O gerente ambiental deve ser bem compreendido em suas idéias, deve definir a direção e as metas, implementar e manter um treinamento e espírito empreendedor.

A primeira atividade consiste em investigar o estágio existente quanto à cultura de segurança, procurando os pontos fracos e problemas potenciais, estabelecer uma política e uma estratégia para a promoção dessa cultura, definir pontos chaves e metas de promoção da cultura de segurança.

Após esse levantamento inicial, implementar as ações identificadas e monitorar a sua efetividade. Em seguida, realizar auditorias para identificar os pontos fracos porventura existentes e novos problemas que ocorreram durante as atividades de preparação.

É importante não se esquecer das empresas contratadas e dos prestadores de serviços terceirizados, caso existentes, como estes se posicionam quanto à cultura de segurança e sistemas de qualidade. Organizando os comentários acima, os seguintes passos devem ser seguidos:

$1^{\mathrm{o}}$ - estabelecer uma política de segurança, e expectativas quanto à cultura de segurança da organização;

$2^{\circ}$ - investigar e avaliar como está a situação da cultura de segurança na organização (postura das pessoas);

$3^{\circ}$ - definir áreas em que a cultura de segurança é essencial, porém não está sendo cumprida adequadamente, que precisam ser melhoradas e reforçadas;

$4^{\circ}$ - definir o conteúdo e o escopo de promoção da cultura de segurança para reforçar áreas carentes;

$5^{\circ}$-definir um grupo de trabalho para promover os conceitos de cultura de segurança, com a participação de facilitadores de cada área organizacional; 
$6^{\circ}$ - definir um cronograma de promoção da cultura de segurança e de auditorias de verificação de conformidade;

$7^{\circ}$ - avaliar os resultados das auditorias e da monitoração, implementando ações corretivas ou preventivas e novas metas de melhoria.

Verificamos que os passos acima enunciados consistem em um PDCA particular para a implementação da cultura de segurança, semelhante ao empregado para a implantação do SGA.

Segundo a ELETRONUCLEAR (2000), é necessário que os indivíduos tenham uma atitude questionadora, rigorosa e prudente e que, antes de iniciar qualquer atividade relacionada à segurança, eles devem levantar questões como:

- entendo a tarefa?

- quais são as minhas responsabilidades?

- como elas se relacionam com a segurança?

- tenho os conhecimentos necessários para proceder corretamente?

- quais são as responsabilidades das outras pessoas?

- há alguma circunstância não usual?

- preciso de algum auxílio?

- o que pode acontecer de errado?

- que consequiência pode ter uma falha ou erro?

- o que pode ser feito para prevenir falhas?

- o que faço se ocorrer uma falha?

Ainda segundo a ELETRONUCLEAR (2000), as pessoas devem ter uma atitude rigorosa e prudente. Esta envolve, pelo menos:

- entendimento do procedimento;

- obediência ao procedimento;

- atenção para o inesperado;

- parada para reflexão quando ocorrerem problemas;

- procura da ajuda necessária;

- atenção à ordem, ao prazo e à limpeza;

- cuidado em todas as ações;

- abandono de simplificações e atalhos.

Para assegurar a efetividade da cultura de segurança, é importante que sejam realizadas auditorias de verificação em segurança nuclear. Se possível, é interessante que 
sejam convidados como auditores os profissionais de outras organizações similares, para que eles tragam as suas experiências do assunto e, além da auditoria, sejam identificadas oportunidades de melhoria. Também devem ser identificados indicadores de desempenho da cultura de segurança.

OBADIA (2002) estudou em profundidade a questão da cultura de segurança, objeto de sua tese de doutoramento, tendo realizado uma avaliação de uma instalação dessa cultura no Instituto de Energia Nuclear, no Rio de Janeiro. Ele preparou uma interessante correlação dos fatores que colaboram para a obtenção de uma cultura de segurança com os critérios de excelência avaliados para a concessão do "Prêmio Nacional de Qualidade". Estes últimos critérios (Modelo de Excelência), foram criados em 1991, com base no Malcolm Baldridge American Quality Award, com o objetivo de identificar organizações de "classe mundial", avaliando oito critérios de excelência: Liderança; Estratégias e Planos; Clientes; Sociedade; Informação e Conhecimento; Recursos Humanos; Processos e Resultados. No trabalho de avaliação do IEN, OBADIA et al (2002) pontuaram os seguintes fatores, ligados aos critérios de excelência do Prêmio Nacional de Qualidade:

- compromisso da alta direção com a segurança;

- liderança evidente;

- alta prioridade à segurança;

- direcionamento sistemático à segurança;

- importância da segurança nos planos estratégicos da organização;

- ausência de conflitos entre a produção e a segurança;

- relacionamento com órgãos licenciadores e regulatórios;

- perspectiva pró-ativa e de longo prazo;

- gerenciamento de mudanças;

- qualidade dos documentos e procedimentos;

- cumprimento de regulamentos e procedimentos;

- pessoal qualificado e bem dimensionado;

- tarefas e responsabilidades bem definidas;

- transparência e comunicação;

- motivação e satisfação no trabalho;

- boas condições de trabalho relacionadas ao tempo de execução, carga de trabalho e stress;

- adequada alocação de recursos; 
- colaboração e trabalho em equipe;

- tratamento de erros no trabalho;

- gerenciamento de conflitos;

- evolução organizacional por meio do aprendizado; e

- compromisso com o desempenho e mérito.

Um trabalho interessante será uma verificação desses fatores na organização em que estivermos com interesse em aplicar o Sistema de Gestão Ambiental.

\subsection{As etapas de verificações e correções}

As normas determinam a necessidade de preparar e implantar:

- procedimentos para monitorar e medir as características das operações que produzam impactos sobre o meio ambiente;

- procedimentos de verificação do cumprimento dos requisitos especificados (por exemplo, nos programas, metas, manual, instruções de trabalho e requisitos legais);

- procedimentos para registro dos resultados.

Para cada área ou atividade importante, deve-se:

- identificar e documentar a informação de verificação a ser obtida e especificar a precisão requerida dos resultados (identificadores de desempenho ambiental);

- especificar e documentar os procedimentos de verificação, os locais e as épocas das medidas;

- preparar, documentar e manter procedimentos de garantia de qualidade, inclusive para a calibração de instrumentos e elaboração de gráficos de controle da qualidade, mantendo registros desse material;

- preparar e manter procedimentos para aquisição de dados e interpretação;

- preparar e documentar critérios de aceitação, bem como as ações a serem tomadas quando os resultados forem insatisfatórios;

- acessar e documentar a validade de dados quando se suspeitar que os sistemas de verificação não estejam funcionando bem;

- verificar que os indicadores de desempenho ambiental sejam confiáveis e que os resultados sejam reproduziveis sob as mesmas condições;

- salvaguardar medidas e instalações de teste de ajustes não autorizados ou avarias. 
A fase de verificação (Check) é importante para comparar se os objetivos e metas foram efetivamente atingidos na fase de execução do plano, ou seja, realizar a confrontação daquilo que foi planejado com aquilo que foi realmente executado.

Esta fase serve, então, para determinar a eficácia do sistema gerencial, e também avaliar os sistemas (equipamentos) da organização, ou seja:

- identificar tudo o que deu certo, conforme planejado;

- identificar os pontos de insucesso, propondo ações corretivas.

\subsection{1 - Monitoramentos e medições}

Monitoramento é o acompanhamento contínuo do processo, tanto gerencial quanto técnico, de modo que a organização disponha, a todo instante, de um conhecimento completo sobre o desempenho de seu sistema de gestão ambiental. Monitorar significa medir ou avaliar, ao longo do tempo.

Controlar, por outro lado, significa tomar as ações para que as atividades e operações sejam realizadas de acordo com um padrão estabelecido, realizando-se os ajustes necessários quando o sistema começa a se afastar desse padrão.

A Norma ISO 14.001 (2004) estabelece que "a organização deve estabelecer, implementar e manter procedimento(s) para monitorar e medir regularmente as características principais de suas operações que possam ter um impacto ambiental significativo. $\mathrm{O}(\mathrm{s})$ procedimento(s) deve $(\mathrm{m})$ incluir a documentação de informações para monitorar o desempenho, os controles operacionais pertinentes e a conformidade com os objetivos e metas ambientais da organização".

Para que esta fase apresente resultados confiáveis, é necessária a existência de indicadores de desempenho, ou seja, formas de medir e comparar, conforme comentado anteriormente, no item 3.3.5 (objetivos e metas). Para cada tipo de variável devem ser definidas as formas de quantificar e avaliar (em se tratando de avaliações gerenciais) ou de medir (em se tratando de variáveis físicas, químicas ou biológicas de processo).

\subsection{2 - Não-conformidades, ações corretivas e ações preventivas}

Não-conformidades são todos os aspectos e valores que não se encontram de acordo com as leis, normas aplicadas (por exemplo, algum item da ISO 14.001), procedimentos e regulamentos estabelecidos pela organização. 
As normas de gestão ambiental exigem que sejam redigidos e implantados procedimentos para identificar as não-conformidades, reais e potenciais, verificar as responsabilidades e definir as medidas corretivas e preventivas necessárias.

Deverão ser também definidos os responsáveis pela documentação, comunicação e correção de não-conformidades, sendo avaliados os riscos potenciais e impactos ambientais decorrentes.

A identificação da necessidade de tomar ações corretivas é, normalmente, resultante de um trabalho de análise sobre o material coletado nas auditorias internas ou da observação dos processos industriais, quase sempre referente a não-conformidades sistêmicas. As ações devem ser proporcionais à extensão dos problemas e à amplitude dos impactos ambientais. Devem ser investigadas as causas das não conformidades, executando-se ações para evitar sua repetição.

As ações corretivas deverão ser baseadas em procedimentos cuidadosamente estudados, avaliados e documentados. O processo de tratamento de não conformidades, por meio de ações corretivas, deve incluir uma análise da eficácia dessas ações, ou seja, se elas foram adequadas e suficientes para remover o problema e impedir a sua reincidência. Identificada uma não-conformidade importante, é necessário investigar as causas que as geraram, de modo a atuar no sentido de evitá-las no futuro. Esse trabalho pode ser realizado, por exemplo, empregando-se um diagrama de Ishikawa. A causa fundamental (principal, para a ocorrência do efeito indesejável) poderá ser tratada como uma ação corretiva (e depois de resolvido o problema, como uma ação preventiva para os casos futuros semelhantes).

A necessidade de tomada de ações preventivas, por sua vez, freqüentemente é mais dificil de ser identificada. Isto porque a não-conformidade ainda não ocorreu, não existe, e por isso mesmo fica mais difícil visualizá-la. Entretanto, sabemos que é muito vantajoso para a organização se conseguirmos identificar a possibilidade dessa ocorrência, principalmente se existir uma situação de risco. Lembra-se o velho ditado, que diz que "é preferível prevenir que remediar". Remediar seria tomar uma ação corretiva. Prevenir, normalmente é mais barato e mais eficiente.

Por ser mais difícil identificar as ações preventivas, sugere-se o uso de algumas planilhas preparadas quando se faz análise de risco. Essas planilhas ajudam a pensar no problema, a estudar com mais detalhes os processos industriais e identificar as possibilidades de risco e, sendo considerado relevante, qual seria a ação para evitar aquela possível situação, que seria a ação preventiva a tomarmos. 
Algumas dessas planilhas são bem simples de serem preparadas, outras um pouco mais trabalhosas. Deve-se escolher o tipo de planilha em função do tempo disponível para o trabalho, ou pela importância e riscos daquele tipo de sistema; se o risco for mais elevado é melhor usar uma planilha mais completa.

A primeira delas, e mais simples, é a planilha denominada "E se?" (What if, em inglês). E se acontecer esta determinada ocorrência, qual a conseqüência?

Outras planilhas (análise ainda qualitativa) interessantes são as de "APP" Análise Preliminar de Perigos e de "HAZOP" - Perigos de Operação.

Existe uma tendência atual muito forte para que as análises de risco quantitativas sejam consideradas como uma ferramenta útil na identificação de ações preventivas. Essas análises vêm sendo realizadas com mais freqüência para as partes consideradas mais críticas dos sistemas industriais com riscos de acidentes com conseqüências ambientais. Os órgãos ambientais têm estimulado esse tipo da análise, por meio das quais, realizando-se cálculos, chega-se a uma determinada "probabilidade" de ocorrência daquele acidente ou daquela determinada falha, diminuindo um pouco a subjetividade que existe na análise apenas qualitativa. A partir daí, o processo se limita a identificar se essa probabilidade é aceitável e, não o sendo, realizar modificações no projeto que levem a uma redução da probabilidade até um nível aceitável. A Figura 3.7 apresenta um resumo dos passos principais, de forma esquemática: 


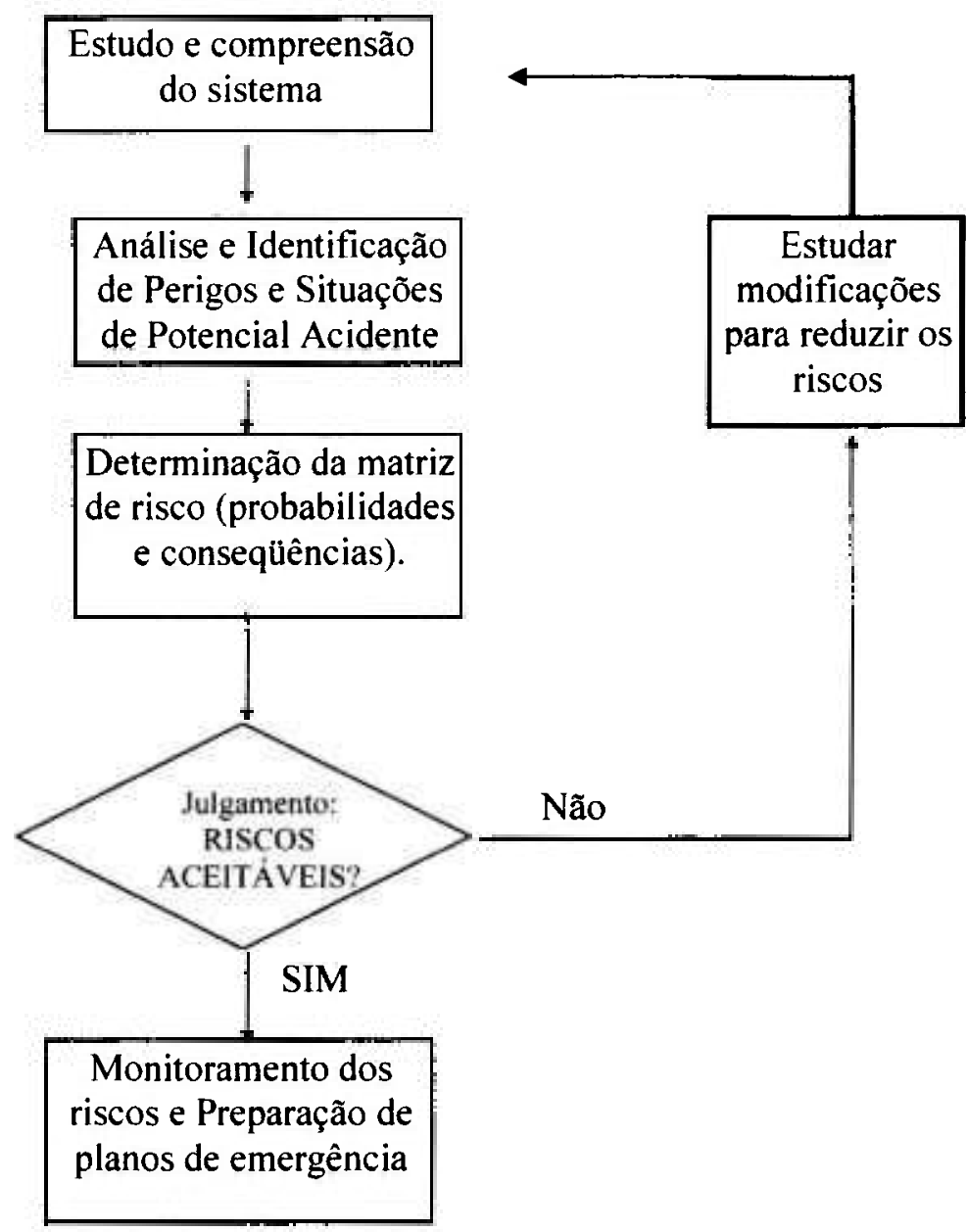

Figura 3.7 - Análise de riscos

Ou, de uma forma mais completa, poderíamos analisar segundo o fluxograma da Figura 3.8: 


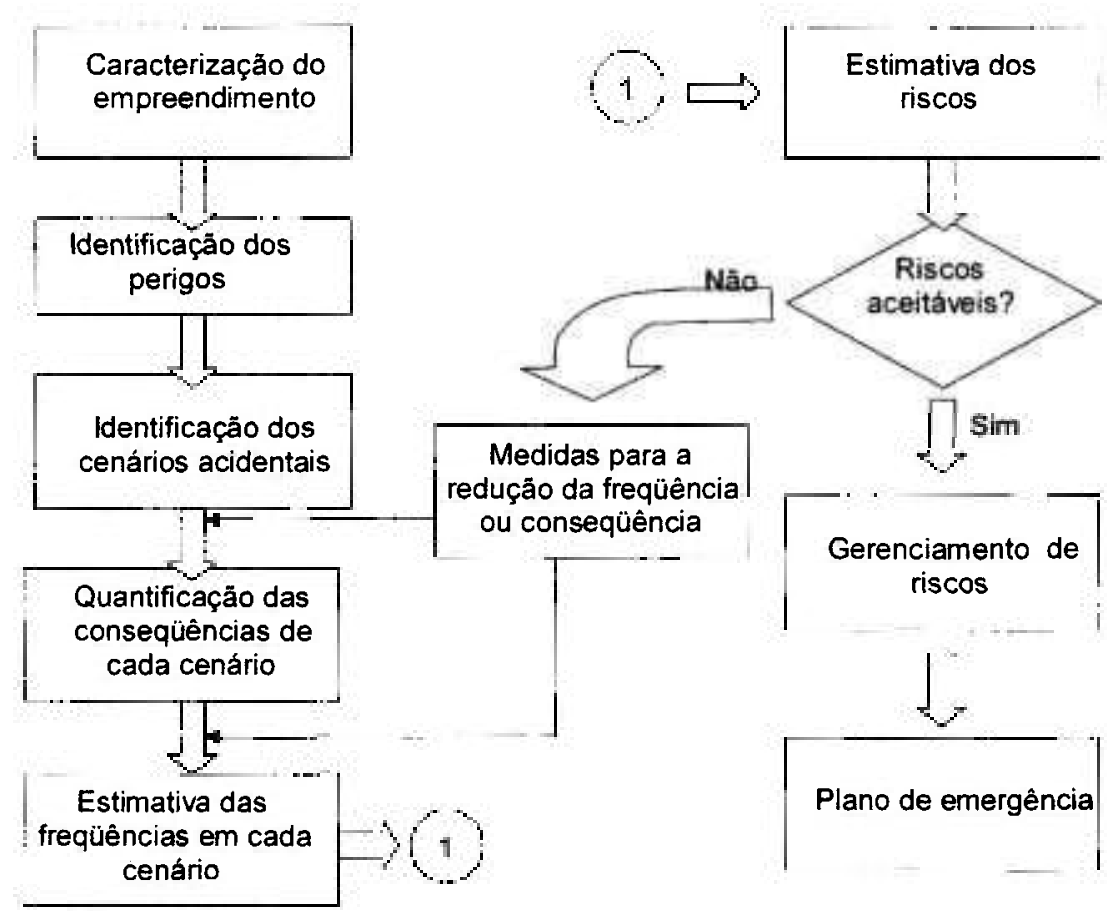

Figura 3.8 - Etapas de uma análise de riscos quantitativa

\subsubsection{Registros}

Os registros ambientais são constituídos por todos os documentos e dados coletados durante todo o processo de implantação e manutenção do SGA, incluindo os documentos de planejamento, treinamento, valores medidos das variáveis físicas e químicas da planta, calibrações e aferições de instrumentos, comunicações, relatórios de auditores. Eles são, na verdade, a prova de que a organização está com o seu SGA atuante durante todo o tempo.

A organização deverá possuir procedimentos formais para a identificação, armazenamento, proteção, recuperação, retenção e descarte de registros (Norma ISO 14.001).

Segundo a norma ISO 14.001 (ABNT, 2004), é recomendado que os registros incluam, entre outros:

- registros de reclamações;

- registros de treinamento;

- registros de monitoramento de processo;

- registros de inspeção, manutenção e calibração; 
- registros pertinentes de prestadores de serviço e de fornecedores;

- relatório de incidentes;

- registros de testes de preparo a emergências;

- resultados de auditoria;

- resultados de análise pela alta administração;

- decisão sobre comunicação externa;

- registros de requisitos legais ambientais aplicáveis;

- registros de aspectos ambientais significativos;

- registros de reuniões ambientais;

- informações sobre desempenho ambiental;

- registros de conformidade legal;

- comunicação com partes interessadas.

Além desses registros sugeridos na Norma, é interessante elaborar outros tipos de registros:

- licenças;

- identificação de produtos: dados de composição e propriedades;

- queixas, ações legais, multas;

- pesos ou volumes de resíduos produzidos;

- resultados de inspeções; e

- informações de empresas contratadas ou fornecedores.

Os registros deverão ser legíveis, correlacionáveis às atividades a que se referem e arquivados (em papel ou banco de dados sob forma eletrônica), de modo a permitir uma fácil recuperação. Em seu processo de arquivamento, os registros deverão ser protegidos de umidade, incêndio, deterioração ou perdas (em arquivos eletrônicos, deverão ser previstos "back-ups", arquivados em local físico separado do original). Todo registro deverá ser mantido por um tempo determinado, findo o qual ele perde sua importância. Nessa ocasião, os registros devem ser destruídos. Os procedimentos devem prever o período de preservação dos registros.

A empresa deve prever, em seus procedimentos, de que forma as informações constantes dos registros estarão disponíveis para os seus empregados, quando eles tiverem necessidade dessas informações na implantação e operação do SGA.

Os procedimentos deverão indicar as ações a tomar no tratamento e arquivamento de registros que contenham informações confidenciais. 


\subsubsection{Auditorias internas}

A Norma NBR ISO 19.011:2002 - Diretrizes para auditorias de sistema de gestão da qualidade e/ou ambiental (ABNT, 2002), define Auditoria como "processo sistemático, documentado e independente para obter evidências de auditoria e avaliá-las objetivamente para determinar a extensão em que os critérios de auditoria são atendidos". E define evidências de auditoria como "registros, apresentação de fatos ou outras informações, pertinentes aos critérios de auditoria". A mesma norma define critérios de auditoria como "conjunto de políticas, procedimentos ou requisitos".

É interessante verificarmos como a norma antiga de auditora ambiental (a ABNT NBR ISO 14.010) a definia:

"A auditoria ambiental é um processo sistemático e documentado de verificação, realizado para obter e avaliar, de forma objetiva, evidências de auditoria para determinar se as atividades, eventos, sistemas de gestão e condições ambientais especificados, ou as informações relacionadas a estes estão em conformidade com os critérios de auditoria, e para comunicar os resultados deste processo ao cliente."

A Norma ABNT ISO 14001:2004 estabelece, em seu item 4.5.5, que a organização deve assegurar que as auditorias internas do sistema de gestão ambiental sejam conduzidas em intervalos planejados para determinar se o sistema de gestão ambiental está em conformidade com os arranjos planejados para a gestão ambiental, incluindo-se os requisitos da Norma, e se foi adequadamente implementado e está sendo mantido. A auditoria também é realizada para fornecer resultados de desempenho do SGA à administração (ABNT, 2004).

As auditorias internas cumprem, dessa forma, um papel interessante no sentido de preparar a organização para a certificação, quando serão realizadas auditorias externas. Assim sendo, a ISO 14.001 determina que a organização estabeleça um ou mais programas de auditoria, levando-se em consideração a importância ambiental das operações pertinentes e os resultados de auditorias anteriores. Também define que devem ser estabelecidos procedimentos de auditoria para tratar das responsabilidades e requisitos para se planejar e conduzir as auditorias, para relatar os resultados e manter os registros associados. Os procedimentos também devem determinar os critérios de auditoria, escopo, freqüência e métodos.

"A seleção de auditores e a condução das auditorias devem assegurar a objetividade e a imparcialidade do processo de auditoria" (ABNT, 2004). Os auditores 
internos devem ser independentes do departamento ou função da área auditada, para evitar as influências indesejáveis (vínculos de subordinação, amizades) que poderiam influenciar na isenção de julgamento. Também é possível que as auditorias sejam realizadas por pessoas externas à organização, que trabalhem em seu nome.

As auditorias de conformidade legal são realizadas para verificar a concordância dos procedimentos com os requisitos legais ou com códigos empresariais e compromissos voluntariamente assumidos pela organização; as auditorias de sistema de gestão ambiental são realizadas para verificação da concordância dos resultados reais com os requisitos da norma de gestão ambiental adotada, da política ambiental, de padrões internos e metas estabelecidas, para verificar o comprometimento e responsabilidades dos administradores, para avaliar as práticas operacionais, avaliar quanto se atingiu dos objetivos e metas tais como redução de riscos, limites de emissões, economias de custos, eficiência de operação, conforme definido em seu escopo (definição inicial sobre os objetivos da auditoria).

As auditorias são realizadas por meio do exame de documentos e registros, entrevistas pessoais, inspeções em campo, reuniões, medições e ensaios, em um processo denominado obtenção de "evidências de auditoria", devendo ser finalizada com relatórios escritos e exposição oral aos diretores e outros funcionários de níveis mais elevados da organização.

A comparação dos objetivos e metas e dos requisitos legais com os valores reais alcançados permite concluir sobre o desempenho ambiental do setor que, consolidado aos outros setores, fornece um retrato da situação da organização.

Um dos objetivos mais importantes, hoje em dia, das auditorias de sistemas de gestão é realizar uma avaliação da eficácia do sistema de gestão em atingir seus objetivos especificados.

A freqüência com que a auditoria deva ser realizada depende da importância ambiental da área envolvida (fatores de risco de problemas ambientais) e dos resultados de auditorias anteriores. As áreas de alto risco, onde ocorram processos complexos, devem ser auditadas com maior freqüência do que as áreas administrativas. Para a organização como um todo, a média recomendada é de 3 anos (auditoria de re-certificação), sendo usual a exigência de uma auditoria simplificada de verificação (cobrindo alguns tópicos da norma e partes da organização), a cada 6 meses. 
Algumas exigências são previstas na norma NBR ISO 19011 como, por exemplo, a de que os objetivos globais do programa de auditoria estejam claramente definidos e documentados, objetivos esses definidos pelo Cliente (ABNT, 2002).

\subsection{A etapa de avaliação}

Esta etapa (fase A do PDCA) é, na realidade, uma fase de "reflexão" sobre os resultados obtidos e definição da estratégia para uma nova rodada do ciclo PDCA. Após o sistema de gestão ambiental ser implementado e colocado em prática, deverá ser feita uma análise cuidadosa das imperfeições e melhorias possíveis a serem incluídas no programa. As revisões são possibilitadas pelos registros de todos os passos, sucessos e fracassos, sobretudo dos relatórios das auditorias ambientais, que realizam as avaliações de uma maneira sistemática, técnica e isenta. Essas revisões devem ser baseadas em procedimentos que definam aquilo que precisa ser monitorado e quais as responsabilidades envolvidas. Esta fase não pode ser confundida com a fase Check do PDCA, pois agora se verifica o conjunto completo das ações, com uma visão bem ampla do processo como um todo, enquanto a fase Check deve se pautar pela verificação de cumprimento daquilo que foi planejado (fase P), do atendimento de leis e regulamentos, ou seja, de áreas mais específicas.

Segundo requisito da ISO 14.001 (ABNT, 2004), a alta administração deve analisar o SGA em intervalos planejados, para assegurar sua continuada adequação, pertinência e eficácia. As análises devem incluir a avaliação de oportunidades de melhoria e a necessidade de alterações no sistema de gestão ambiental, inclusive da política ambiental e dos objetivos e metas ambientais. Devem ser mantidos registros dessas análises.

Essa revisão, realizada com responsabilidade, é uma das medidas mais importantes para obtenção de um processo de melhoria contínua. Em particular, deverão ser avaliadas as modificações na legislação, os eventuais acidentes e incidentes, os relacionamentos e desejos das partes interessadas e as mudanças tecnológicas que tenham ocorrido com relação aos produtos, equipamentos da planta e processos produtivos, sempre com a visão de melhoramento contínuo, passo a passo, com o estabelecimento de novos níveis de controle. Se, eventualmente, for observado que os resultados obtidos já são satisfatórios, esta fase deve ser aproveitada para consolidação dos procedimentos, por meio da padronização das ações.

Recomenda-ser que a alta direção programe e realize uma reunião anual, na qual o responsável pelo SGA apresente um resumo do desempenho obtido, com fatos e dados que retratem o cumprimento da política ambiental, dos objetivos e metas, sucessos e 
insucessos, custos decorrentes, ressaltando as eventuais vantagens em prosseguir o programa. Com o apoio, principalmente dos relatórios de auditorias (internas e externas), deverá ser feita uma discussão sobre a postura estratégica da organização em face às questões ambientais, definindo-se o rumo a seguir, com eventual revisão da política, objetivos e metas. 


\section{PROPOSTA DE IMPLANTAÇÃo DE UM SISTEMA DE GESTÃo AMBIENTAL NO LABORATÓRIO DE REJEITOS RADIOATIVOS DO IPEN}

A CNEN mantém atualmente os seguintes depósitos de rejeitos radioativos:

\section{- Depósito definitivo:}

Em Abadia de Goiás, localizada a $25 \mathrm{~km}$ do centro de Goiânia, especialmente construído para receber os rejeitos resultantes do acidente com a abertura indevida de uma cápsula contendo Césio-137, ocorrido em 1987.

- Depósitos intermediários:

Localizados no Instituto de Pesquisas Energéticas e Nucleares (IPEN, na Cidade Universitária, USP - São Paulo), no Centro de Desenvolvimento da Tecnologia Nuclear (CDTN, na Cidade Universitária, UFMG, Belo Horizonte) e no Instituto de Energia Nuclear (IEN, na Cidade Universitária, UFRJ, Rio de Janeiro).

Este trabalho visa, especificamente, um estudo de caso para o Laboratório de Rejeitos Radioativos do IPEN e, com as devidas modificações, poderá ser de utilidade para os demais depósitos intermediários operados pela CNEN.

\subsubsection{Laboratório de Rejeitos Radioativos do IPEN}

O Laboratório de Rejeitos Radioativos do IPEN é constituído por um edifício principal de 2 pavimentos de $15 \times 35 \mathrm{~m}$ e três galpões para armazenagem de rejeitos, com uma área total de $460 \mathrm{~m}^{2}$.

O Laboratório recebe, trata e armazena rejeitos radioativos de baixa e média atividades, provenientes de outras unidades do IPEN, além de rejeitos provenientes de indústrias, clínicas e outras instituições externas, principalmente das regiões sul e sudeste do país.

O Laboratório conta atualmente com a participação de 12 pessoas: 6 pesquisadores ( 5 dos quais são doutores), 5 técnicos e uma secretária, além de bolsistas e estagiários.

De um modo geral, os rejeitos recebidos podem ser classificados em 7 categorias, em função de seus diferentes métodos de tratamento:

a) líquidos; 
b) sólidos compactáveis;

c) sólidos não compactáveis;

d) biológicos;

e) fontes radioativas;

f) pára-raios radioativos; $\mathrm{e}$

g) detectores de fumaça radioativos.

Logo após serem recebidos no andar térreo do edifício principal, os materiais são separados por categorias em uma sala, sendo encaminhados para tratamento, de acordo com a sua categoria.

a) rejeitos líquidos, que são originados principalmente de instalações do próprio IPEN. Entre eles, ressaltam-se as resinas de troca iônica, utilizadas no reator IEA-R1, com atividade mais elevada. Existe um projeto para tratar esses rejeitos, incorporando-os em uma matriz sólida, construindo blocos de concreto, a serem enviados futuramente para um repositório final.

b) sólidos compactáveis: trata-se de uma série de materiais utilizados em instalações que manipulam materiais radioativos (produção de radioisótopos, fabricação de combustíveis nucleares etc.), tais como luvas, papel toalha, sacos plásticos de embalagens etc. A compactação é realizada com uma prensa de $10.000 \mathrm{kgf}$. Esse procedimento reduz o volume dos rejeitos em cerca de 5:1. O material compactado é colocado em tambores de 200 litros, que ficam, a seguir, estocados em um dos galpões.

c) sólidos não compactáveis: tratam-se de materiais diversos (ferramentas, peças metálicas etc.), que ficaram contaminados e cuja descontaminação não se justifica, principalmente do ponto de vista econômico, para permitir a continuidade de uso ou o descarte como resíduo convencional. Esses materiais também ficam estocados em tambores de 2001 ou caixas metálicas de 1300 litros.

d) biológicos: constituem-se principalmente de restos de animais utilizados em experimentos científicos. Sofrem tratamento por desidratação, são calcificados e armazenados em tambores metálicos de 200 litros.

e) fontes radioativas: as fontes em desuso (mas que ainda contém material radioativo), utilizadas pela indústria (gamagrafia, medidores de nível etc) e aplicações médicas (radioterapia e radiodiagnóstico) são enviadas pelos usuários ao LRR. Essas fontes são armazenadas em uma sala ou em um dos galpões. Foi instalada uma célula quente para que seja feita a abertura da fonte, retirando-se o material radioativo, a ser 
depositado em recipientes especiais com blindagem de chumbo, até sua deposição em repositório final.

f) pára-raios: muitos pára-raios antigos utilizavam materiais radioativos (principalmente Amerício-241 e poucos com Rádio-226). Havia a idéia de que provocando-se a ionização do ar próximo ao pára-raios, este aumentava a sua eficiência na proteção, atraindo os raios. Avalia-se que tenha sido produzido, no Brasil, um total de 75.000 pára-raios radioativos; destes, cerca de 20.000 foram recuperados, sendo que 16.000 estão armazenados no LRR e 4.000 no CDTN (Minas Gerais). Quando o páraraios é recebido, é separado o material radioativo contido em uma pequena plaqueta, que é removida retirando-se seus rebites. $\mathrm{O}$ restante do material metálico (aço e cobre) do pára-raios está sendo armazenado, aguardando-se a conclusão dos estudos para o estabelecimento de uma metodologia para a sua descontaminação, para posterior descarte como sucata metálica comum.

g) detectores de fumaça: muitos detectores utilizam o Am-241, porém com baixa atividade. Cerca de 20.000 deles foram recolhidos ao LRR, sendo desmontados em uma bancada para a retirada do material radioativo; o restante do dispositivo é descartado como resíduo comum.

\subsection{Política Ambiental}

Com base nas recomendações do Capítulo 4, sugere-se a seguinte política ambiental para o LRR:

\section{POLÍTICA AMBIENTAL}

Nós, do Laboratório de Rejeitos Radioativos do IPEN, consideramos que a proteção ambiental e a saúde pública são aspectos fundamentais das nossas atividades. Dessa forma, assumimos os compromissos de:

- melhorar continuamente nossos processos e serviços, de modo a reduzir os impactos ambientais de nossas atividades;

- respeitar as legislações federal, estadual e municipal e normas da CNEN e de outros órgãos ambientais, relacionadas às nossas operações;

- prevenir a poluição, adotando práticas que protejam o meio ambiente e a saúde de nossos trabalhadores;

- atuar para reduzir o consumo de recursos naturais, evitando desperdícios;

- motivar e treinar nossos colaboradores, visando sua atuação com eficácia; 
- relatar prontamente às chefias superiores quaisquer incidentes e deficiências observadas no laboratório, relacionadas à proteção ambiental;

- procurar utilizar materiais alternativos não tóxicos e adotar práticas para minimizar as liberações de materiais perigosos ou radiação para o meio ambiente.

Para auxiliar a organização na consecução desses compromissos, implantamos um Sistema de Gestão Ambiental, cujos objetivos e metas serão constantemente atualizados e disponibilizados às partes interessadas.

São Paulo, xx de xxxxx de xxxx

Assinatura do responsável pelo LRR

\subsection{Comprometimento com a Política Ambiental}

A Direção do IPEN deve estar comprometida com a implementação, a manutenção e o aperfeiçoamento do SGA, provendo os recursos necessários para as atividades requeridas.

No nível do Laboratório de Rejeitos Radioativos (LRR), seu dirigente máximo deverá demonstrar o mesmo comprometimento.

Iniciado o processo, deverão ser realizadas reuniões formais com todos os membros do LRR, para que tomem conhecimento da Política Ambiental, e seja assegurado um comprometimento de todos em relação aos dispositivos dessa política. Essas reuniões deverão ser registradas em atas, para conhecimento futuro dos auditores.

Deverá ser formado um grupo de trabalho, composto de representantes dos vários setores existentes no laboratório, para conduzir as atividades de implementação do Sistema de Gestão Ambiental. A liderança desse grupo será exercida por algum profissional designado como "Gerente Ambiental" do LRR. Todos os componentes do laboratório deverão colaborar com os trabalhos, incluindo os de identificação dos impactos ambientais e análise dos perigos.

O cumprimento das leis é uma necessidade para qualquer organização, e parte relevante da Política Ambiental. Esse compromisso foi expressamente declarado na Política Ambiental do LRR. É responsabilidade de todos os dirigentes do IPEN e do LRR, apoiados pelos setores operacionais, em cumprir a Política Ambiental estabelecida. 
Estes devem avaliar a aplicabilidade das exigências legais e de outras partes interessadas (por exemplo, da CNEN, demandas dos vizinhos e de outras áreas do IPEN) quanto à relevância, devendo informar as áreas envolvidas sobre as prescrições aplicáveis e a forma de implementação dos requisitos legais. Os funcionários encarregados desse trabalho, designados formalmente pelo responsável pelo LRR, devem seguir procedimentos específicos para a realização desta tarefa.

\subsection{Identificação dos aspectos e impactos ambientais}

Para cumprir esta etapa da implantação do Sistema de Gestão Ambiental, haverá a necessidade de que o Grupo de Trabalho identifique todos os processos e serviços realizados pelo LRR, identifique os rejeitos radioativos armazenados, os produtos químicos e outros materiais de consumo, as situações de risco envolvidas (visando os impactos potenciais e as situações de perigo), avaliando-se todo o ciclo de vida do laboratório, desde o planejamento de novos programas, serviços e experimentos, avaliando-se os novos projetos, construção, operação, manutenção, até o descomissionamento e encerramento das atividades.

Apresenta-se, na Figura 4.1, um exemplo de fluxograma de processo das atividades relacionadas aos materiais recebidos pelo LRR para tratamento $\mathrm{e}$ armazenagem, elaborado de forma preliminar, a ser futuramente melhor detalhado pelos técnicos do LRR. Percorrido na vertical, o fluxograma indica a seqüência de operações, desde a entrada dos rejeitos até a sua armazenagem. No lado esquerdo de cada bloco, são registradas as entradas de materiais e energia, referentes àquela determinada etapa do processo, enquanto do lado direito são registradas as saídas, freqüentemente associadas à geração de impactos ambientais. 


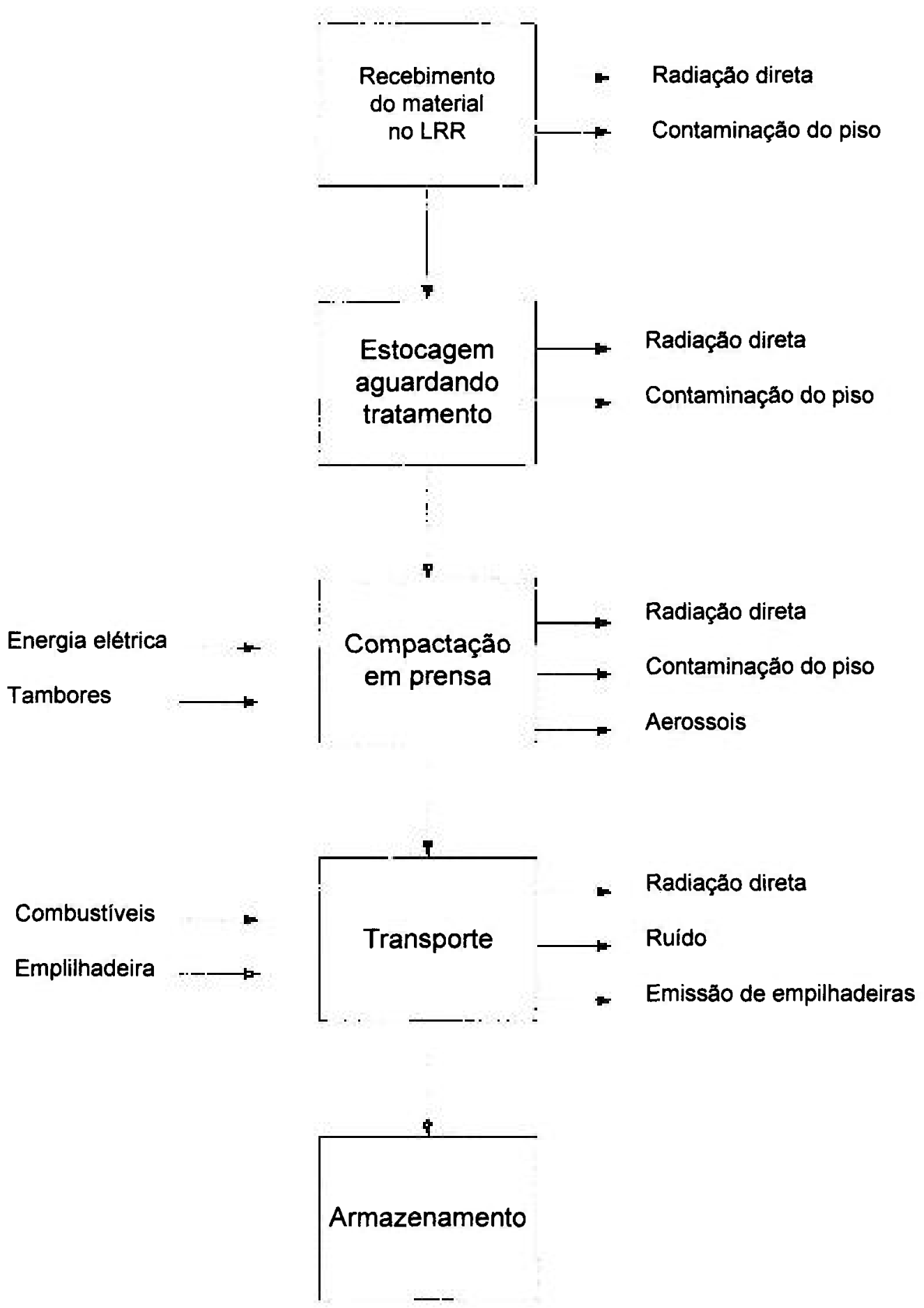

Figura 4.1 - Fluxograma de processo de tratamento de sólidos compactáveis

A Listagem de Fluxogramas existentes poderá auxiliar no controle dos processos, assegurando que todas as áreas importantes do LRR foram avaliadas. Sugere-se a planilha de controle da Tabela 4.1. 
Tabela 4.1 - Planjlhas ale cuntroble de tlunogramas de prizesso

\begin{tabular}{|c|l|l|l|l|}
\hline IPEN / CNEN/ LRR & \multicolumn{3}{|c|}{ CONTROLE DE FLUXOGRAMAS DE PROCESSO } \\
\hline $\begin{array}{c}\text { Número do } \\
\text { Fluxograma }\end{array}$ & Atividade & Responsável & $\begin{array}{c}\text { Datas de } \\
\text { emissão/ } \\
\text { revisão }\end{array}$ & Observações \\
\hline & & & & \\
\hline & & & & \\
\hline & & & & \\
\hline & & & & \\
\hline & & & & \\
\hline Preparado por: & Data: & Aprovado por: & Data: & \\
\hline
\end{tabular}

A partir do fluxograma apresentado como exemplo, observam-se os seguintes aspectos ambientais principais e os correspondentes impactos ambientais:

\begin{tabular}{|l|l|}
\hline Emissão de radiação ionizante & $\begin{array}{l}\text { Exposição direta do trabalhador e } \\
\text { indivíduos do público }\end{array}$ \\
\hline Emissão de aerossóis & $\begin{array}{l}\text { Contaminação do piso } \\
\text { Contaminação do ar interno e externo à } \\
\text { instalação }\end{array}$ \\
\hline Liberação de efluentes líquidos & $\begin{array}{l}\text { Contaminação de águas } \\
\text { Contaminação do solo }\end{array}$ \\
\hline Ruído & Incômodo aos trabalhadores \\
\hline Incêndio & $\begin{array}{l}\text { Destruição patrimonial e contaminação } \\
\text { do ar e do solo }\end{array}$ \\
\hline $\begin{array}{l}\text { Outros eventos da natureza (ventos fortes, } \\
\text { tornados) }\end{array}$ & $\begin{array}{l}\text { Destruição patrimonial e contaminação } \\
\text { do ar e do solo }\end{array}$ \\
\hline Descarte de baterias e pilhas & Contaminação do solo \\
\hline Descarte de óleo usado & Contaminação do solo e de águas \\
\hline Consumo de energia elétrica & Esgotamento de recursos \\
\hline Consumo de água & Esgotamento de recursos naturais \\
\hline Vazamentos de água & Esgotamento de recursos naturais \\
\hline $\begin{array}{l}\text { Estabilidade estrutural inadequada do } \\
\text { produto e/ou embalado }\end{array}$ & $\begin{array}{l}\text { Riscos de falha estrutural, com } \\
\text { contaminação do solo e do ar }\end{array}$ \\
\hline $\begin{array}{l}\text { Riscos de vazamento de gases gerados no } \\
\text { embalado }\end{array}$ & Contaminação do ar \\
\hline $\begin{array}{l}\text { Degradação microbiana no produto, } \\
\text { devido à presença de matéria orgânica }\end{array}$ & Contaminação do solo e do ar \\
\hline $\begin{array}{l}\text { Embalagens projetadas com materiais } \\
\text { com baixa resistência à corrosão }\end{array}$ & Contaminação do solo, de água e do ar \\
\hline
\end{tabular}


Na implantação de um Sistema de Gestão Ambiental no LRR, os trabalhos de identificação dos impactos e sua priorização deverão ser realizados pelos componentes do grupo de trabalho, de forma a serem levadas em conta várias opiniões, de pessoas com maior experiência no assunto.

A priorização dos impactos ambientais deverá ser feita de forma a subsidiar a etapa seguinte, que é a definição dos objetivos e metas. Entre outros fatores a serem levados em consideração, devem ser analisados os riscos (eventos potenciais) que as atividades e os processos podem acarretar ao meio ambiente e à saúde de colaboradores e público externo ao LRR. Estes riscos devem ser determinados e avaliados com base em critérios rastreáveis e, a partir dos critérios, serem definidas metas e ações para prevenir os impactos ambientais adversos.

A priorização dos impactos ambientais deverá levar em conta vários fatores, entre os quais estão:

- os requisitos legais e outros requisitos ambientais aplicáveis à organização;

- os compromissos estabelecidos na Política Ambiental;

- a severidade e a magnitude dos impactos ambientais;

- a demanda das partes interessadas no desempenho ambiental da organização (público externo, CNEN, IBAMA, outras áreas do IPEN);

- as opções tecnológicas existentes, disponíveis, para a melhoria dos processos, levando-se em conta os aspectos técnicos e econômicos (melhor técnica disponível sem acarretar custos excessivos).

Na Tabela 4.2 é apresentado um exercício de priorização dos impactos ambientais anteriormente identificados. 


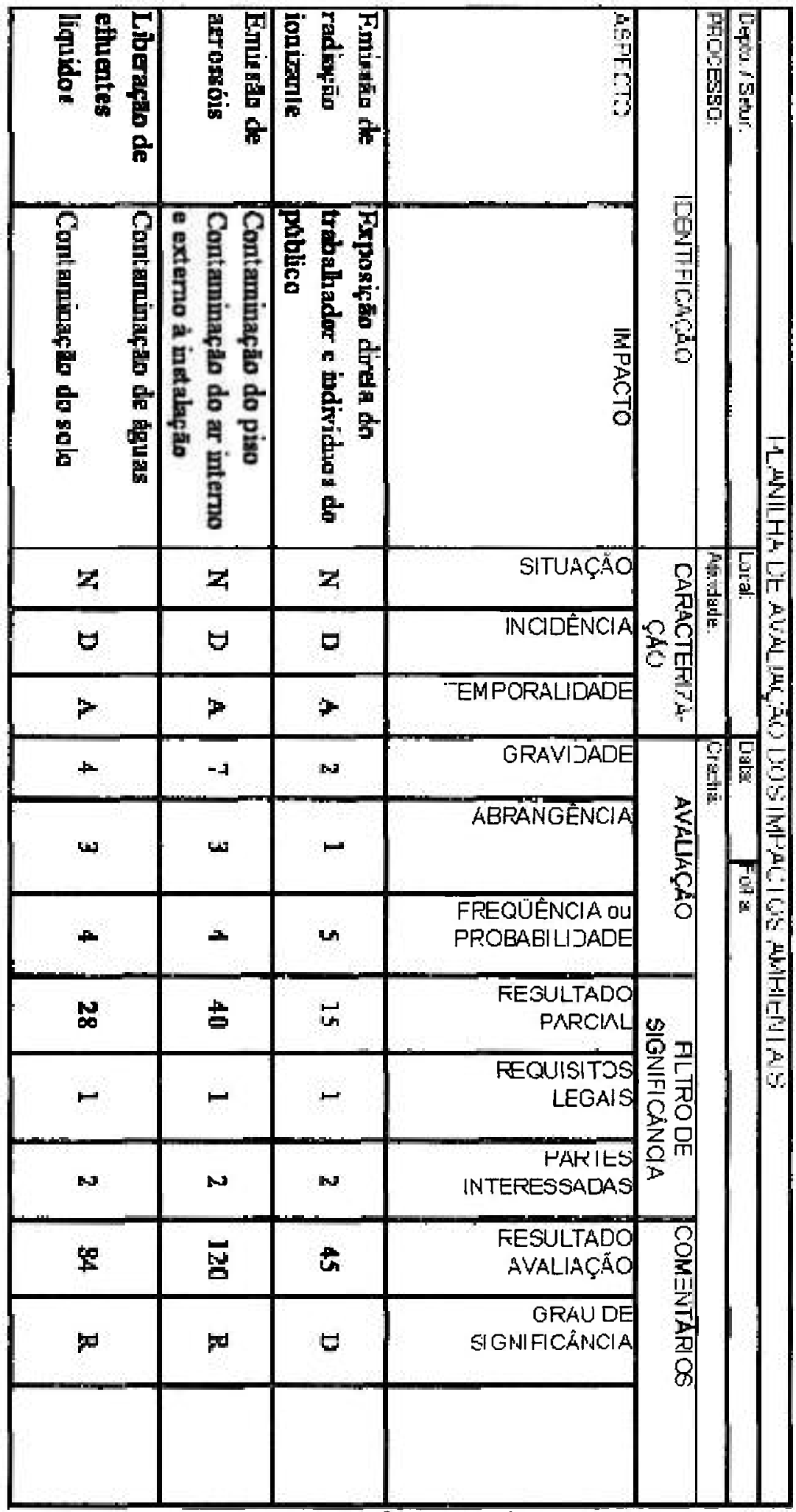

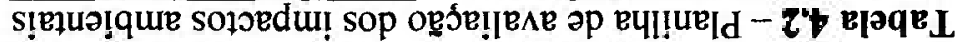




\subsection{Proposta de objetivos e metas}

As metas deverão ser estabelecidas segundo os processos "top down - bottom up" (de cima para baixo - de baixo para cima), de maneira mensurável. Algumas delas, as "top down" serão emanadas da alta direção do IPEN ou do LRR, originárias da Política Ambiental, enquanto outras (as "bottom up") são originárias da análise dos processos e estabelecidas pelo grupo de implantação do SGA, conforme o item anteriormente apresentado.

Para que as metas possam ser alcançadas, deverão ser planejados e atribuídos prazos, recursos, responsabilidades e competências, na etapa seguinte do processo, que é a elaboração do Plano de Ação. Os objetivos e metas deverão ser estabelecidos pela equipe do LRR, com base na lista completa de aspectos e impactos ambientais identificados ao se realizar o trabalho de implantação do SGA e na priorização destes impactos.

Como exemplos, podem ser citados:

Objetivo 1: Reduzir a emissão de efluentes líquidos e gasosos.

Meta 1: Caracterizar e quantificar todas as emissões líquidas, até agosto de 2008.

Meta 2: Caracterizar e quantificar todas as emissões gasosas, até agosto de 2008.

Meta 3: Estudar processos alternativos de tratamento de rejeitos, em relação àqueles já implementados no LRR, até junho de 2009.

Objetivo 2: Garantir a proteção física das instalações do LRR

Meta 1: Instalar câmaras de vigilância nos arredores do LRR, até agosto/2008

Meta 2: Introduzir sistema eletrônico de alarme e controle de acesso a todas as áreas controladas, até dezembro de 2008

Meta 3: estabelecer um programa de divulgação e treinamento sobre rejeitos radioativos para todos os funcionários terceirizados do IPEN, até junho/2008.

\subsection{Proposta de um Plano de Ação}

O Plano de Ação deverá agregar às informações de caracterização dos impactos (qual impacto, local de sua geração etc.) outras informações relacionadas às metas, sendo atribuídos prazos, recursos, responsabilidades e competências.

A planilha a seguir, na Tabela 4.3, a ser preenchida pelos componentes do grupo de implantação do SGA, contém um exemplo de um Plano de Ação. 


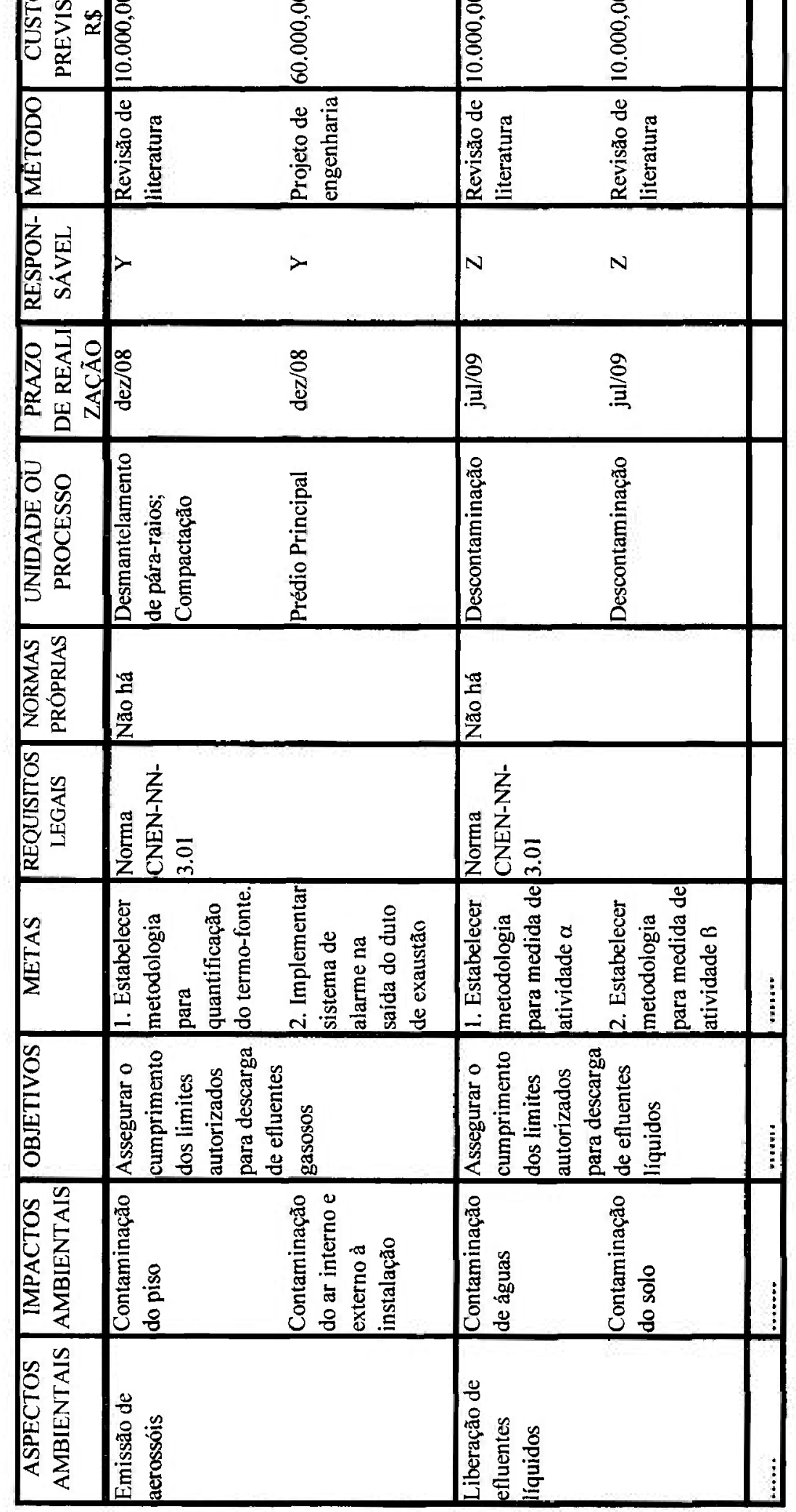




\subsection{Comunicações internas e externas}

Os procedimentos a serem preparados deverão estabelecer a sistemática de comunicação com as partes interessadas em relação ao SGA do LRR, definindo as formas de comunicação (meios, freqüência e tipo de informação).

Os seguintes canais poderão ser utilizados como forma de atingir eficácia das comunicações:

a) comunicações internas: intranet, informativos internos, quadros murais, caixas de sugestões, mala direta eletrônica para os funcionários do LRR, quadro de "certo e errado" (fotografias);

b) comunicações externas: internet, formulário de demanda de partes interessadas externas, palestras e publicações em revistas e jornais, folhetos do próprio LRR, campanhas ambientais realizadas (semana de meio ambiente, semana da CIPA).

Deve-se atribuir prioridade às respostas quando:

a) as comunicações tratarem-se de uma reclamação de partes interessadas (nesse caso, elaborar um registro de ocorrência ou relatório de não-conformidade);

b) as comunicações tiverem como origem um órgão de controle ambiental (CETESB, IBAMA, SMA), Universidades e ONGs;

c) as comunicações tiverem como origem órgãos de comunicação de massa (jornais, emissoras de TV, rádio);

d) as comunicações proporcionarem uma oportunidade de melhoria para o SGA.

Os colaboradores e grupos interessados externos, principalmente os geradores de rejeitos radioativos, devem receber informações relativas ao meio ambiente, necessárias à compreensão da contribuição do LRR, sendo importante a construção de um diálogo aberto entre as partes.

Segundo CLARKE (2003), a comunidade local deve ser informada dos processos de tomada de decisões. Um processo de sucesso requer:

- envolvimento do público no início do processo;

- reconhecimento e respeito a outros pontos de vista;

- clara compreensão do processo de tomada de decisões. 
As consultas sobre meio ambiente e segurança do trabalho, referentes ao LRR, deverão ser encaminhadas ao responsável pela implantação ou manutenção do SGA no LRR, sendo respondidas com o envolvimento dos respectivos setores.

As reclamações de partes interessadas devem ser encaminhadas aos setores competentes do IPEN e ao responsável pelo LRR, sendo devidamente respondidas.

Os contatos com órgãos governamentais e autarquias relativas ao meio ambiente e segurança ocupacional deverão ser realizados pela Direção do IPEN.

\subsection{Conscientização e treinamento}

Todos os funcionários do LRR devem receber treinamentos de conscientização, para mostrar a colaboração que cada um deles pode dar à sociedade em relação às questões ambientais mais relevantes, ressaltando-se os principais impactos ambientais causados pelas atividades do Laboratório e as conseqüências para o meio ambiente e para o público externo dos desvios de conduta em relação aos procedimentos estabelecidos. Os treinamentos devem visar a obtenção de conhecimentos de caráter geral relacionados à questão ambiental e conhecimentos técnicos específicos. Visam também à manutenção e ao aperfeiçoamento dos conhecimentos, habilidades e aptidões dos colaboradores.

As chefias das áreas do LRR deverão levantar todas as necessidades de treinamento de seus setores, para que estes sejam programados, preparados e aplicados de acordo com um cronograma a ser estabelecido. Deverão ser treinados principalmente os funcionários cujas tarefas possam gerar um impacto significativo para o meio ambiente, com base na avaliação dos aspectos e impactos ambientais, perigos e riscos e nãoconformidades identificadas em auditorias.

Os treinamentos precisarão ser repetidos (melhorando-os) com uma determinada regularidade, para manter os conhecimentos atualizados.

O SGA deverá colaborar na identificação de novos requisitos regulatórios e necessidades para treinamento

O LRR deverá manter programas de treinamento, visando conscientizar os seus funcionários quanto:

- à Política Ambiental do LRR;

- à identificação e análise dos aspectos e impactos ambientais relevantes relacionados às atividades do laboratório; 
- aos benefícios ambientais resultantes das boas práticas, ao cumprimento da Norma ISO 14.001 (ABNT, 2004) e um desempenho melhorado;

- ao papel e responsabilidade de cada profissional na execução de seus trabalhos, em conformidade com a Política Ambiental e requisitos do SGA, bem como das conseqüências das não-conformidades;

- ao cumprimento dos procedimentos operacionais e instruções de trabalho ligadas ao meio ambiente;

- ao atendimento dos requisitos legais;

- ao conhecimento dos requisitos básicos do sistema;

- aos perigos envolvidos nos processos e material armazenado no LRR;

- à preparação para resposta a emergências.

O desenvolvimento técnico dos colaboradores pressupõe uma qualificação contínua, preparando-os para a realização com competência das tarefas atuais (e futuras), bem como tornando-os aptos para serem promovidos, assumindo funções com nível maior de responsabilidades.

$O$ aperfeiçoamento do colaborador deve ser, principalmente, uma responsabilidade do seu superior imediato. Para auxiliá-lo, os funcionários devem expor às suas chefias as suas necessidades de treinamento.

Adicionalmente ao levantamento das necessidades de treinamento realizado pelo superior hierárquico, a área de Recursos Humanos do IPEN deve encaminhar propostas de treinamento à Diretoria, visando à implementação de novos sistemas, tecnologias e mudanças previstas para o LRR em suas instalações e processos. Também deverão ser previstos treinamentos específicos em ferramentas da qualidade (Controle Estatístico de Processos, Análises de Modos de Falhas e seus Efeitos, Auditoria da Qualidade, Métodos de Análise e Solução de Problemas etc.).

Periodicamente, os chefes de cada área do LRR devem determinar e documentar a necessidade de qualificação de cada funcionário.

As ações de treinamento realizadas devem ser documentadas, por exemplo, em um "registro de treinamento", indicando-se o título do treinamento, carga horária, instrutor, nome e assinatura dos participantes e resultado de uma avaliação de desempenho (se houver). 
Procedimento para treinamento, bem como os registros de treinamentos, devem ser mantidos disponíveis para consulta na administração do LRR e na área de Recursos Humanos do IPEN.

A eficácia do treinamento deve ser avaliada, em um primeiro estágio pelo superior imediato do colaborador e, mais tarde, por auditorias internas.

Em suma, os treinamentos devem ser realizados para assegurar que todos os funcionários do LRR executem seus trabalhos de maneira segura, levando em conta a proteção ambiental.

\subsection{Estrutura de preparação e controle de documentos}

O LRR deverá manter um controle dos documentos e registros, com o propósito de orientar o cumprimento da sua Política Ambiental e dos demais requisitos da Norma ISO 14.001 e da legislação, bem como evidenciar esse cumprimento.

O Manual de Gestão Ambiental do LRR do IPEN, como documento principal do sistema, deverá apresentar, de forma resumida, os processos e métodos utilizados na implantação e manutenção do SGA; ele deverá descrever, em uma visão sistêmica, as responsabilidades e autoridades dos funcionários e das chefias em todas as fases do processo.

Todos os documentos importantes do LRR deverão ser controlados, à semelhança dos documentos do sistema da qualidade. O controle deve incluir as etapas de emissão, liberação, distribuição, alteração, arquivamento, cancelamento e disposição final dos documentos. O processo de controle deve ser exercido independentemente do tipo de midia, por exemplo, papel, meio eletrônico ou outra forma de registro de dados. Somente os originais dos documentos deverão ser assinados.

Os documentos do SGA podem ser classificados em:

- documentos internos, como por exemplo, o Manual de Qualidade Ambiental (nível estratégico), Procedimentos Sistêmicos (nível tático), Procedimentos Operacionais, Instruções de Trabalho, Especificações de Processo, Desenhos, Diretrizes, Normas Internas, Listas de controle de rejeitos, entre outros (nível operacional); e,

- documentos externos, por exemplo, regulamentações legais, normas da CNEN, normas nacionais e internacionais aplicáveis à instalação, e também as consultas de partes interessadas. 
Para cada documento, deve ser mantido um registro que contenha os seguintes dados:

- nome do documento (título);

- codificação do documento;

- data de sua emissão ou revisão;

- responsáveis pela emissão, aprovação e alterações;

- responsáveis pela liberação;

- tipo e tempo de arquivamento;

- tipo de disposição ou proteção contra uso indevido.

Todas as determinações do sistema de gestão ambiental para assegurar o planejamento, a realização e o controle dos processos, bem como os seus resultados, devem ser documentados e arquivados, incluídas as obrigações de cumprimento da legislação e normas da CNEN. Também devem ser levadas em conta as normas internas relacionadas à proteção de dados e segurança de informações e à forma de arquivamento ou destruição de documentos e dados.

Os documentos internos devem ser revistos sempre que necessário; no mínimo, deverá ser feita uma revisão semestral para análise crítica sobre a validade (adequação à norma ISO 14.001 e outros requisitos legais) e utilidade (aplicabilidade) dos documentos.

Os documentos internos deverão ser aprovados pelas chefias das áreas. No caso de revisão, as modificações devem ser analisadas e aprovadas pelas mesmas chefias que assinaram o documento original. Quando a aprovação envolver mais de uma área, o emitente deverá indicar as áreas envolvidas, cujos chefes também assinarão o documento.

Um dos problemas mais freqüentes de controle de documentos é decorrente do uso, cada vez maior, da intranet para distribuição e uso de documentos, principalmente procedimentos e instruções de trabalho. Existem grandes vantagens no uso deste meio, tais como a velocidade de disseminação, custo reduzido, a minimização das cópias em papel (e, consequentemente, menor quantidade a ser descartada quando os documentos ficam obsoletos e superados) etc. Porém, há dificuldade em se garantir o uso da versão atualizada, devendo-se evitar o uso de cópias feitas pelo usuário e arquivadas em seu computador pessoal, pois, eventualmente, podem ter se tornado superadas. $\mathrm{Na}$ distribuição via intranet, serão válidas sempre as versões dos documentos disponibilizados, retirando-se do sistema as versões obsoletas. Os redatores dos documentos são responsáveis pela sua correção e identificação clara. Como, atualmente, muitos dados são arquivados em computadores, 
deverá ser assegurado um mecanismo para assegurar a preservação e acesso a esses dados (disponibilidade), no período mínimo previsto para arquivamento.

Existe a necessidade de se controlar as autorizações de aprovação de documentos em meio eletrônico, sendo uma forma mais comum o uso de senha (password), restrita ao funcionário autorizado.

Os documentos controlados disponíveis apenas em papel deverão ser identificados quanto à sua validade, por meio da aposição de carimbo, identificação manual ou outro meio apropriado. $\mathrm{O}$ usuário, devidamente cadastrado junto ao setor emissor, deve receber automaticamente a nova edição ou informação de cancelamento, pelo setor da qualidade responsável pelas novas emissões dos documentos. Poderá ser utilizado um "Protocolo de Entrega" para confirmação de recebimento. A responsabilidade pela destruição ou identificação do documento obsoleto é do usuário, ou do setor da qualidade responsável pelo sistema de documentação, dependendo do interesse da organização, manifestado por procedimento específico.

Os documentos liberados e disponíveis para consulta em meio eletrônico deverão ser considerados como "Cópias Controladas" e válidos para utilização. As cópias controladas deverão conter um carimbo com a inscrição "Cópia controlada" preferencialmente na cor vermelha. Cópias em papel, a partir desta, serão válidas desde que correspondam ao documento no meio eletrônico. A responsabilidade pela verificação da validade do documento compete ao usuário. Os originais dos documentos obsoletos deverão conter um carimbo com essa informação. Suas cópias deverão ser destruídas, quando do recebimento das novas revisões.

Deverá ser elaborado um índice contendo a lista de todos os documentos do SGA do LRR, identificando a situação de revisão atualizada dos documentos.

Deve-se assegurar que as emissões atualizadas de documentos estejam disponíveis nos locais onde são realizadas operações essenciais e de risco de exposição, cabendo essa atribuição aos responsáveis pelos setores, bem como a retirada de uso dos documentos obsoletos. Os documentos mantidos para registro histórico devem ser assim identificados, de forma a evitar o seu uso inadequado.

\subsection{Resposta em situações de emergência}

Com base nos aspectos ambientais potenciais, relacionados às situações de risco e na vulnerabilidade intrínseca do meio ambiente, devem ser avaliados os riscos de ocorrência dos impactos ambientais associados a estes aspectos e suas conseqüências. 
Deverá ser elaborado um Plano de Emergência, de modo a atender, de forma rápida (com prontidão) e eficaz, os potenciais acidentes, contribuindo para eliminar ou reduzir os impactos ambientais e as consequeências de maior dano. A elaboração do Plano de Emergência deve ser útil na adoção de ações preventivas.

O Plano de Emergência deverá contemplar todos os procedimentos a serem seguidos em casos de acidentes radiológicos ou nucleares, contendo instruções sobre as ações a serem tomadas durante e após uma situação de emergência; os procedimentos deverão indicar os responsáveis pelas ações.

Para a implantação do Plano de Emergência, a administração deverá providenciar os recursos materiais e humanos necessários.

O Plano de Emergência deverá ser revisado periodicamente; na ocorrência de um acidente, o Plano deverá ser imediatamente analisado e revisto.

Deverão ser realizados, tanto quanto possível e com uma certa periodicidade, exercícios e simulações de acidentes previstos no Plano de Emergência, como forma de treinamento do pessoal envolvido e verificação da pertinência das ações previstas.

Os procedimentos deverão ser revistos em função dos resultados de exercícios simulados que tenham sido realizados, de novas e prováveis situações de emergência identificadas e de modificações em processos e mudanças organizacionais implementadas.

\subsection{Monitoramento e medições}

Deverá ser elaborado e implementado no LRR um Plano de Monitoramento e Medições, com o objetivo de verificar o desempenho ambiental do laboratório e o cumprimento dos objetivos e metas ambientais estabelecidas no Plano de Ação, bem como verificar o nível de atendimento aos requisitos legais e normas ambientais aplicáveis.. Os locais de medição e as características das amostras deverão ser especificados, bem como preparados os formulários para registro dos valores medidos.

As áreas de metrologia do LRR deverão ter como meta reduzir continuamente o número de não conformidades nos processos de calibração dos equipamentos de monitoramento e medição. Os equipamentos devem ser calibrados e controlados de acordo com procedimentos documentados, sendo a calibração feita por comparação com padrões nacionais ou internacionais rastreáveis. Todos os equipamentos devem ser registrados no sistema, antes de entrarem em uso. A cada equipamento deverá ser atribuída uma 
identificação de controle, devendo-se prever inspeções periódicas e sistemáticas quanto ao seu funcionamento apropriado e precisão.

O processo de controle dos equipamentos deverá ser descrito em procedimentos de inspeção e calibração, que poderão ser elaborados individualmente para um equipamento específico, ou em procedimentos de inspeção e calibração normalizados, válidos para uma série de equipamentos com características similares.

Quando a calibração dos equipamentos de monitoramento e medição for feita por laboratórios de metrologia externos, estes deverão ser acreditados por órgão oficial para as grandezas de medição correspondentes.

Caso os equipamentos sejam calibrados em laboratórios próprios do IPEN, estes deverão ser apropriados aos tipos de equipamentos, adequadamente equipados e com pessoal técnico qualificado.

O escopo do laboratório, tipos e magnitude de calibrações e/ou ensaios deve atender as diretrizes da Norma NBR ISO/IEC 17025 (ABNT, 2004). Os métodos utilizados devem ser rastreáveis a métodos internacionalmente aceitos.

Quando não houver a disponibilidade de um laboratório certificado pela Norma ISO/IEC 17025, deverá ser realizada uma auditoria no laboratório candidato com base nos requisitos dessa norma. Comprovada a qualificação do laboratório, deverá haver uma aprovação da CNEN para este uso. Também poderão ser utilizados os serviços de calibração realizados pelos fabricantes dos equipamentos.

Os registros dos resultados da calibração devem ser arquivados.

Sugere-se o uso da planilha apresentada na Tabela 4.4, como um documento de controle das monitorações e medições. Além dela, deverão ser construídas planilhas específicas para monitoração dos processos do LRR. 
Tabela 4.4 - Plano de monitorações e medições

\begin{tabular}{|c|c|c|c|c|c|c|}
\hline $\begin{array}{l}\text { CNEN / IPEN } \\
\text { LRR }\end{array}$ & \multicolumn{4}{|c|}{ PLANO DE MONITORAÇÕES E MEDIÇÕES } & Documento & Data: \\
\hline $\begin{array}{l}\text { Categoria do } \\
\text { monitoramento }\end{array}$ & Local & $\begin{array}{l}\text { Parâmetro } \\
\text { avaliado }\end{array}$ & $\begin{array}{l}\text { Valores } \\
\text { limites }\end{array}$ & $\begin{array}{l}\text { Método de } \\
\text { avaliação }\end{array}$ & Freqüência & \\
\hline $\begin{array}{l}\text { Nivel de atendimento } \\
\text { dos requisitos legais e } \\
\text { normas aplićáveis }\end{array}$ & & & & & & \\
\hline $\begin{array}{l}\text { Nível de cumprimento } \\
\text { dos objetivos e metas }\end{array}$ & & & & & & \\
\hline $\begin{array}{l}\text { Qualidade dos } \\
\text { efluentes líquidos }\end{array}$ & & & & & & \\
\hline $\begin{array}{l}\text { Emissōes para a } \\
\text { atmosfera }\end{array}$ & & & & & & \\
\hline $\begin{array}{l}\text { Descarte de resíduos } \\
\text { sólidos }\end{array}$ & & & & & & \\
\hline $\begin{array}{l}\text { Controle dos níveis de } \\
\text { radiação }\end{array}$ & & & & & & \\
\hline $\begin{array}{l}\text { Desempenho dos } \\
\text { controles operacionais }\end{array}$ & & & & & & \\
\hline $\begin{array}{l}\text { Controle de } \\
\text { equipamentos de } \\
\text { medidas }\end{array}$ & & & & & & \\
\hline Preparado por: & Data: & Revisado & & Aprova & por: & Data: \\
\hline
\end{tabular}

\subsection{Controle de registros}

Em todas as fases do processo de implantação e manutenção do SGA, devem ser registrados os resultados de reuniões, acordos, análises e inspeções. Os registros auxiliam na definição e atribuição de responsabilidades. Os tipos de registro e sua forma devem ser definidos em procedimentos.

Deverá ser criado um procedimento que estabeleça métodos para identificar, coletar, indexar, arquivar, manter e dispor os registros ambientais. Os registros têm a finalidade de permitir a rastreabilidade dos dados ambientais das atividades e serviços do LRR.

Os registros devem conter, entre outras, as seguintes informações: nome do registro, tipo, codificação, local de arquivamento, data, emitente, aprovador (se necessário), tempo mínimo de arquivamento, tipo de disposição ou proteção contra uso indevido e distribuição entre interessados. Os dados ambientais deverão ser registrados em formulários preenchidos à mão ou em sistema eletrônico de processamento de dados, sendo arquivados de forma a permitir uma rápida e fácil recuperação. Devem ser arquivados em local que não permita deterioração ou dano, e controlados para evitar a sua perda. 
Os registros devem ser mantidos para demonstrar, em qualquer instante, a conformidade do SGA implantado com os requisitos estabelecidos em legislação, normas e procedimentos estabelecidos para o LRR.

\subsection{Indicadores de desempenho}

Uma das fases mais importantes da etapa de avaliação do SGA (fase C), consiste no estabelecimento e verificação dos indicadores de desempenho.

A avaliação dos resultados alcançados, quanto ao grau de implementação do SGA e eficácia das ações, deve ser feita regularmente pela Direção do LRR, em conjunto com as várias áreas técnicas e gerenciais.

O reconhecimento precoce dos pontos fracos, a definição de ação corretiva e a pronta disponibilização dos recursos necessários, irão permitir que os requisitos impostos pela CNEN, por novas leis e outras partes interessadas, sejam rapidamente atendidos.

Com base nas metas fixadas no Plano de Ação e nos procedimentos estabelecidos, devem ser fixados os indicadores de desempenho aplicáveis ao laboratório. Como exemplos, podem ser citados:

a) consumo de energia elétrica (em MWh por ano);

b) consumo de água ( $\mathrm{em}^{3}$ por ano);

c) geração de águas servidas (em $\mathrm{m}^{3}$ por ano);

d) emissões na atmosfera (em $\mathrm{t}$ por ano ou Bq por ano);

e) geração de Resíduos (em t por ano ou Bq por ano);

f) quantidade (em $\mathrm{m}^{3}$, ton ou $\mathrm{Bq}$ ) de rejeitos radioativos armazenados no LRR;

g) percentagem de metas atingidas;

h) número de não conformidades por ano, identificadas em auditorias;

i) número de ações corretivas por ano;

j) número de ações corretivas implementadas em relação ao número de ações corretivas necessárias;

k) eficácia do controle de equipamentos, verificando-se o número de dispositivos de monitoramento e medição calibrados, por unidade de tempo;

1) despesas e custos de controle dos equipamentos, avaliando-se os custos em relação ao orçamento total do LRR;

m) intervalos médios de re-calibração dos equipamentos do LRR; 
n) percentagem de funcionários treinados em questões ambientais;

o) satisfação dos funcionários (avaliada com base em pesquisas de opinião);

p) participação dos funcionários em seminários e congressos (índice em relação ao total de colaboradores);

q) absenteísmo dos funcionários (avaliado com base em índices de ausência por doenças, licenças, faltas);

r) vida útil média dos equipamentos;

s) número de reclamações de partes interessadas;

t) número de ações de melhoria sugeridas;

u) número de ações de melhoria implantadas em relação ao número de ações de melhoria sugeridas;

v) estatística de acidentes;

w) estatística de doenças do trabalho e doenças ocupacionais.

\subsection{Auditorias internas}

O IPEN deverá realizar avaliações do SGA implementado no LRR, para obter informações relevantes para a Administração e para subsidiar a Direção do LRR, referentes aos seguintes temas:

- desempenho de processos;

- resultados de auditorias;

- resultados de implementação de ações preventivas e corretivas;

- modificações que podem influir sobre o sistema de gestão; e

- recomendações de melhorias.

As auditorias internas têm por finalidade colaborar com a melhoria do sistema de gestão ou de parte dele, em relação ao atendimento dos requisitos da política ambiental, procedimentos e demais requisitos da norma ambiental adotada (ISO 14.001), além do cumprimento da legislação vigente e de normas da CNEN. As auditorias também irão avaliar a eficácia do SGA, ou seja, se o sistema está devidamente implementado e mantido, verificando-se o cumprimento dos objetivos e metas estabelecidos e do plano de ação, além dos procedimentos e instruções de trabalho. Realizando-se auditorias, é confirmado o cumprimento das atividades planejadas e a eficácia do sistema de gestão. A chefia do LRR tem a responsabilidade de definir e apoiar a realização das auditorias internas, realizadas em intervalos regulares (definidos em procedimento), avaliar os resultados e adotar as medidas necessárias para monitorar sua eficácia. 
As auditorias deverão ser planejadas cuidadosamente, definindo-se:

a) Objetivos da auditoria: conforme a própria definição de auditoria, trata-se de um processo sistemático e documentado para determinar, com base em evidências objetivas, se as atividades do SGA e seus resultados estão de acordo com os requisitos estabelecidos para o sistema em sua política, plano de ação e procedimentos, verificando-se se as ações necessárias foram implementadas com eficácia e se elas estão adequadas para a atingir os objetivos pretendidos; também visam comunicar os resultados da avaliação à administração.

b) Escopo da auditoria: deverão ser verificadas todas as áreas internas que tenham envolvimento com os elementos do SGA, obtendo-se amostras das evidências de cumprimento dos requisitos do sistema.

c) Freqüência das auditorias: todos os elementos do SGA implementado no LRR devem ser auditados ao menos uma vez por ano.

As auditorias internas devem ser realizadas por auditores qualificados. Como o número de funcionários do LRR é reduzido, é desejável que os auditores sejam externos à unidade, sendo convidados funcionários de outras áreas do IPEN para a realização desse trabalho, o que aumenta a isenção e independência dos auditores em relação à área auditada. $O$ recrutamento deve ser feito com base em uma lista de auditores qualificados, com cursos de qualificação para auditores ambientais, internos ou externos. Quando necessário, poderão ser chamados auditores externos, também devidamente qualificados.

O roteiro apresentado, a seguir, poderá ser usado para orientar a seqüência de passos na realização das auditorias internas. É importante que a equipe responsável pela implantação do SGA conheça o processo de realização de uma auditoria, para que exista uma melhor compreensão do papel de cada um dos participantes e seja entendido o modo de trabalho dos auditores externos, caso seja decidida a obtenção de certificação do SGA. Dessa forma, será facilitado o relacionamento auditor-auditado. Um clima de entendimento sobre a importância da auditoria, e do seu modo de realização, colabora para o sucesso final. Os seguintes passos podem ser seguidos:

a) Definição da realização da auditoria interna

Essa definição é feita pela direção do LRR, aprovando a indicação do Gerente Ambiental, seguindo um cronograma de realização de auditorias (no mínimo uma auditoria anual em cada årea). 
b) Seleção do auditor líder

Deverá ser indicado pelo IPEN um auditor-líder, a quem caberá uma grande parcela de autoridade e responsabilidade em todas as ações decorrentes. $\mathrm{O}$ auditor líder deverá determinar a abrangência, o escopo (extensão e limites, se total, ou cobrindo apenas algumas unidades ou áreas específicas do LRR) e os critérios de auditoria. A auditoria somente poderá ser iniciada se o auditor-líder estiver convencido de que:

- existem informações suficientes e apropriadas a respeito do objeto da auditoria;

- existe cooperação adequada por parte das áreas auditadas; $\mathrm{e}$

- existem recursos adequados para apoiar o processo.

$O$ auditor-líder será o responsável final por todas as fases da auditoria, devendo ter uma boa experiência e capacidade gerencial, liderança e autoridade para tomar decisões finais com relação à condução da auditoria. Ele representará a equipe de auditoria perante as áreas auditadas e ao representante da administração do IPEN, cabendo a ele a condução dos trabalhos e a elaboração e apresentação do relatório final.

c) Preparação da auditoria

O auditor-líder, com o auxílio do gerente ambiental, deverá realizar uma análise preliminar das áreas a serem auditadas, examinar a documentação do SGA aplicável em cada área, coletar informações iniciais sobre os processos existentes, os aspectos ambientais relacionados aos serviços, o sistema de gerenciamento ambiental implantado, a importância ambiental da área, os resultados (registros) de auditorias anteriores e outras informações relevantes, de modo a identificar as especialidades requeridas dos auditores, visando a preparação das listas de verificação a serem seguidas.

Também como preparação, ele deverá listar os critérios e padrões a serem empregados na auditoria.

$\mathrm{O}$ auditor-lider deverá informar às áreas auditadas os objetivos e metas da auditoria (procura de conformidades).

d) Seleção da equipe de auditoria

O auditor-líder deverá selecionar os componentes da equipe de auditoria, participando essa escolha à Direção do LRR. Deve ser verificada a independência dos auditores em relação à área auditada, ausência de preconceitos de qualquer tipo, não 
podendo ocorrer conflitos de interesse nem idéias ou fatos do passado que prejudiquem uma completa isenção. É imprescindivel que os auditores selecionados possuam os conhecimentos, as habilidades e a experiência requeridos para aquele tipo de auditoria a ser realizada, dentro da área coberta por cada um.

e) Planejamento da auditoria pela equipe

A equipe de auditoria, nesta fase, deverá se preparar para a auditoria propriamente dita.

A primeira etapa consistirá em receber as orientações do auditor-líder, ouvir sua explanação sobre o material por ele levantado anteriormente sobre os processos e a legislação, sobretudo a respeito do sistema de gerenciamento ambiental do LRR e dos objetivos a serem atingidos, identificação das unidades organizacionais a serem auditadas, cronograma das reuniões e requisitos de confidencialidade. Deverá ser feita, também, uma clara atribuição de responsabilidades entre os auditores.

Deverá, a seguir, ser feito o planejamento detalhado da auditoria, com gráficos de Gantt (tempos esperados para as atividades de maior duração, datas de início e fim) e outras ferramentas gerenciais de planejamento (atividades, tempos, responsabilidades, redes de precedência etc.), e definidos os métodos de trabalho e os critérios da auditoria.

Segundo a norma ISO 19011 - Diretrizes para auditorias de sistema de gestão da qualidade e/ou ambiental, "critério de auditoria é o conjunto de políticas, procedimentos ou requisitos" (ABNT, 2002). Os critérios de auditoria são usados como uma referência para a avaliação da "evidência de auditoria". Deverão ser preparados pela equipe os formulários para relatar as observações de auditoria e documentar evidências (que darão suporte às conclusões dos auditores) e listas de verificação (ckeck lists) com os questionários de auditoria, a serem respondidos nas primeiras reuniões, bem como os procedimentos de auditoria, caso necessário. A preparação dos check lists é uma das fases mais importantes para o sucesso de uma auditoria e sua qualidade será muito influenciada pela capacidade dos auditores e da experiência (banco de dados da empresa). Não se deve improvisar, iniciando-se a auditoria sem os check-lists, pois fatalmente os auditores se esquecerão de verificar tópicos importantes, que comprometerão as conclusões finais.

Os critérios devem ser objeto de acordo entre o auditor-líder e a direção do LRR, sendo comunicados aos responsáveis pelas áreas auditadas, tendo o grau de detalhamento adequado. O plano de auditoria deverá ser suficientemente flexível, para permitir eventuais mudanças na ênfase com que alguns assuntos serão tratados, 
dependendo das informações que serão coletadas durante o desenrolar da auditoria (as listas de verificação devem ser vistas como um "guia" e não como um "trilho").

Deverão ser preparadas as listas de dúvidas e pontos a serem esclarecidos nas primeiras reuniões. Todos os documentos de referência deverão ser identificados, tais como a norma que "contra a qual" a auditoria se referencia, o manual de qualidade ambiental, entre outros documentos.

A equipe deverá preparar a agenda da auditoria.

Os auditores deverão ter conhecimento dos procedimentos de emergência e de segurança das instalações em que irão trabalhar, para evitar riscos pessoais.

\section{f) Reunião de abertura}

Deverá ser realizada uma reunião de abertura como início da auditoria entre a equipe de auditores e a equipe do LRR. Em alguns casos, é recomendável que exista até mesmo uma pré-auditoria (com cerca de dois diaş de duração), como ferramenta de preparação.

O auditor-líder, depois de apresentar a equipe de auditores, deverá explicar todos os passos que serão cumpridos nos trabalhos de auditoria, discutir (e rever, se for o caso) o escopo, a abrangência e o planejamento, os métedos que serão empregados, os critérios de auditoria, o prazo para finalização dos trabalhos, definir os canais de comunicação oficiais entre as equipes de auditores e auditados, confirmar a disponibilização de recursos e facilidades solicitados, confirmar a hora e a data de reuniões entre as equipes, horários das visitas e auditorias a cada local do LRR, esclarecer quaisquer dúvidas a respeito do plano de auditoria e discutir os pontos principais dos documentos e material anteriormente recebidos. O processo de auditoria deve ser concebido para proporcionar um nível desejado de confiabilidade das constatações e conclusões, tanto para os auditores, como para a direção do LRR.

g) Conhecimento do sistema de gerenciamento ambiental

O sistema de gerenciamento ambiental é composto pela estrutura organizacional, responsabilidades, práticas, procedimentos, processos e recursos para implantação do gerenciamento ambiental.

A equipe de auditoria deverá verificar de que forma a administração do LRR realiza o gerenciamento de todas as atividades relacionadas ao controle ambiental, se ela compara os resultados obtidos (desempenho) com os valores especificados como requisitos, 
e quais são e como atuam os mecanismos de controle para garantir esse cumprimento em um processo contínuo.

Os auditores deverão procurar indicativos e evidências que demonstrem o cumprimento (conformidades) ou descumprimento (não-conformidades) dos compromissos assumidos e requisitos da norma. Estas constatações podem ser dos seguintes tipos:

- físicas: constatações e observações visuais do auditor, na observação dos instrumentos e equipamentos do LRR. A calibração dos instrumentos deverá ser verificada, antes de confiar plenamente nos seus resultados;

- documentais: observações dos registros e medições feitas anteriormente à auditoria, bem como das atividades previstas e efetivamente realizadas quanto ao sistema de gerenciamento ambiental;

- declaratórias: observações colhidas a partir de depoimentos dos funcionários do LRR durante as entrevistas. De preferência, esses indícios deverão ser confirmados por um dos dois métodos adicionais expostos, com fatos e dados.

Uma das partes importantes da auditoria é a realização de entrevistas, visitas aos vários locais do LRR relacionados à armazenagem dos rejeitos, emissões, processos etc, que se complementam com a análise dos documentos e realização de alguns ensaios e testes de amostras, para confirmar medições. Nessa fase deverão ser confirmadas (por um dos métodos acima) as informações prestadas na fase inicial de fornecimento de informaçðes. Todas as informações obtidas deverão ser documentadas e interpretadas, para serem utilizadas como evidências de auditoria. É interessante lembrar que as atividades da auditoria estão sujeitas a incertezas, já que o processo é baseado em amostragens, razão pela qual se justifica uma grande persistência por parte do auditor na busca de confirmações, quando as evidências não forem muito claras. As informações obtidas de entrevistas e que pareçam indicar não conformidades, deverão ser confirmadas por outras fontes (registros, medidas, observações físicas, documentos etc.).

Deverão ser obtidas, entre outras, as seguintes informações (também denominadas indícios):

- existência real do sistema de gerenciamento ambiental (não somente no papel);

- confrontação completa dos requisitos da norma ambiental adotada com o material apresentado pelo LRR (política, procedimentos etc.); 
- verificação da conformidade das instalações com a legislação federal, estadual e municipal, atualidade das licenças de órgãos ambientais governamentais;

- responsabilidades reais das pessoas alocadas ao sistema de gerenciamento ambiental e comprovação de treinamentos desse pessoal;

- aspectos ambientais dos produtos estocados no LRR, atividades e modo como o Laboratório controla esses aspectos;

- desempenho do LRR em termos de emissões e descargas, quantidades recebidas de matéria prima, uso de água e de energia, armazenagem de produtos químicos e outros materiais perigosos etc.;

- identificação e classificação dos resíduos perigosos;

- identificação do destino final dos resíduos, bem como das condições de sua armazenagem e transporte;

- visita e inspeção das vizinhanças do LRR, observando emissões e ruído;

- verificação da existência de queixas de vizinhos e da comunidade;

- levantamento do histórico de problemas ambientais do LRR;

- levantamento de resultados de auditorias anteriores para, comparando com a situação atual, verificar as ações de melhoramento contínuo;

- levantamento de resultados de inspeções de órgãos governamentais;

- identificação dos passivos ambientais do LRR (depósitos de resíduos perigosos, condições do aqüiffero sob o terreno e vizinhanças, ações trabalhistas relacionadas a problemas ambientais);

- identificação dos gastos incorridos com a correção de problemas ambientais;

- análise dos procedimentos elaborados para uso em situações de emergência (planos de contingência);

- verificação da existência e desempenho de controles e alarmes para prevenir situações de risco;

- análise do sistema empregado para identificar e corrigir as deficiências observadas, por meio de inspeções e auditorias internas;

- verificação da efetividade do treinamento de pessoal para as funções ligadas à qualidade ambiental. 
A qualidade e quantidade das evidências devem permitir a auditores competentes, trabalhando independentemente $\mathrm{e}$ sob as mesmas condições, obter constatações similares na avaliação das mesmas evidências.

Os auditores, bem como os futuros usuários dos resultados da auditoria devem estar conscientes de que as evidências coletadas serão apenas uma amostra das informações disponíveis (o período de tempo e os recursos são limitados), portanto existirão sempre elementos de incerteza no processo. Por isso, o auditor ambiental deve se empenhar em obter evidências suficientes para permitir um bom julgamento da questão (constatações isoladas significativas e conjunto de constatações menos significativas).

h) Análise de indícios de conformidades e não-conformidades

Após a auditagem de todas as atividades previstas no planejamento, a equipe de auditores deve reunir todas as suas observações para determinar quais devem ser enquadradas como não-conformidades, que deverão ser identificadas em termos de requisitos específicos da norma ISO 14001 ou outros documentos, com base nos quais foi realizada a auditoria. A equipe de auditoria deve garantir que as não-conformidades sejam expostas de maneira clara, concisa e apoiadas por evidências objetivas. Quando várias nãoconformidades se referirem a um mesmo assunto, elas devem ser agrupadas e registradas somente uma vez (por exemplo, se for constatado uso de documentos obsoletos em 3 áreas diferentes do LRR, não serão 3 não-conformidades e sim 1 não-conformidade, ocorrendo em 3 locais).

Devem ser também identificadas as não-conformidades potenciais para aspectos ambientais importantes, como parte de um processo preventivo. Esse reconhecimento poderá ser feito com base em um estudo de FMEA (Análise de Modos de Falha e seus Efeitos), estudos aprofundados de confiabilidade (probabilidades de falhas) etc., apresentados ou solicitados pelo auditor. Dessa forma, a gerência do LRR poderá "a priori" tomar ações preventivas para as possíveis falhas (introdução de redundâncias, reforços estruturais, melhoria de controles etc.).

Lembramos que a não-conformidade somente deverá ser aberta se o auditor tiver os três elementos designados como "RVC": Requisito da norma, Violação e Caso (evidência objetiva).

Todas as observações de não-conformidade devem ser conhecidas pela gerência do auditado. 
i) Avaliação global de dados levantados

Os resultados da auditoria deverão ser baseados em fatos comprovados por evidências documentadas e possíveis de serem reconstituídas.

Esta fase poderá ser realizada cumprindo os seguintes passos:

- participação à equipe do LRR das não-conformidades principais;

- interação entre os membros da equipe de auditoria para rever as observações sobre áreas comuns, e assegurar a completeza das informações (atuação como um time);

- revisão de resultados de amostras, eventualmente enviadas a laboratórios para confirmação de resultados;

- preparação de um resumo de resultados e conclusões parciais;

- análise crítica dos resultados, evitando-se generalidades;

- preparação da reunião de encerramento.

j) Preparação do relatório preliminar

O relatório deverá ser preparado em linguagem clara, precisa e concisa. Deverá estar muito apoiado em fatos e dados, citando-se os eventos e os itens de regulamentos, leis ou normas que não estão sendo cumpridos, se for o caso. Ao final deste item estão colocados, como sugestão, dois formulários padronizados para acompanhamento de auditorias, sobretudo as internas (Tabelas 4.4 e 4.5). $\mathrm{O}$ conjunto destes formulários, para todas as áreas analisadas, fornece subsídios para os relatórios preliminar e final.

O relatório preliminar deverá ser apresentado formalmente na reunião de encerramento. Para que não surjam dúvidas e controvérsias importantes, recomenda-se que o auditor líder realize, anteriormente, uma reunião com o responsável geral pelo LRR para relatar as não-conformidades, convocando-se outros participantes de cada uma das partes envolvidas no processo, caso necessário.

Se o escopo da auditoria houver previsto esta atividade, o auditor-líder poderá incluir sugestões de melhoria no SGA do LRR, a partir dos fatos levantados e de sua experiência.

k) Reunião de encerramento.

A reunião de encerramento deverá ser realizada com o objetivo de apresentar as constatações da auditoria aos auditados, com a presença de toda a equipe de auditores, o gerente do LRR e sua equipe. É recomendável que os gerentes conheçam todos os resultados da auditoria antes dos escalões mais altos da organização, dentro da filosofia de 
gerenciamento responsável. É importante que seja percebido que a auditoria foi fortemente baseada em fatos e dados comprováveis, sendo esta a ocasião apropriada para a solução de divergências ou dúvidas de ambas as partes. $O$ auditor-líder deverá conduzir a apresentação, devendo ser redigida uma ata de reunião. É importante que a alta administração do IPEN, com o apoio do chamado "Representante da Direção (RD)" participe da reunião e entenda claramente os resultados da auditoria. As seguintes recomendações podem ser seguidas para um bom desenvolvimento dos trabalhos:

- apresentar o propósito da reunião e um panorama geral da auditoria antes de entrar em detalhes específicos;

- indicar as metas da auditoria, o modo de sua realização, os participantes no LRR;

- apresentar em detalhes cada não-conformidade registrada no relatório preliminar;

- verificar se os participantes estão compreendendo satisfatoriamente todos os pontos apresentados;

- responder às dúvidas e solicitar esclarecimentos às suas dúvidas, se existirem;

- registrar todos os comentários feitos pelo pessoal do LRR, em ata de reunião;

- encerrar a reunião.

I) Atividades finais da auditoria

As atividades finais consistem na elaboração do Relatório da Auditoria (relatório final) e sua distribuição à alta direção da organização. $O$ relatório final deverá ser preparado sob a responsabilidade do auditor-líder, que deverá datá-lo e assiná-lo. Deverão ser registrados o local, organização ou unidade auditada, época da realização da auditoria (datas de início e período de tempo), objetivos e escopo inicial definidos, critérios acordados em relação aos quais a auditoria foi realizada, documentos de referência contra os quais a auditoria foi conduzida, funções auditadas, equipe de auditores, equipe de representantes do LRR, padrões de referência, declaração explícita de confidencialidade dos resultados, descrição sumária do processo de auditoria e principais resultados, observações de não-conformidades, conclusões da auditoria e outras informações relevantes, como por exemplo, um julgamento da equipe auditora quanto à extensão do atendimento à norma ISO 14.001 (ABNT, 2004). Deverá ser indicada a lista de distribuição de exemplares desse relatório. Deverão ser indicados tanto os pontos positivos quanto os negativos observados, levando em conta os comentários havidos na reunião de 
encerramento, bem como um sumário do processo de auditoria, incluindo quaisquer obstáculos encontrados.

O relatório deverá registrar comentários sobre o cumprimento de leis e regulamentos, indicar os pontos observados nos quais há riscos de responsabilização legal dos gerentes e dirigentes da organização, apresentar sugestões de ações corretivas e melhorias dos processos (principalmente das causas fundamentais das não-conformidades ou das causas potenciais à ocorrência de não-conformidades, em uma abordagem preventiva) indicando idéias de custos para implementação dessas melhorias (se isso fizer parte do escopo definido), fazer comparações entre o desempenho de unidades equivalentes (por exemplo, outros laboratórios equivalentes do IEN e CDTN, caso já tenham sido feitas auditorias ambientais nessas unidades). A linguagem deverá ser clara, precisa e concisa, devendo-se procurar adotar um enfoque pró-ativo, ou seja, é melhor apresentar oportunidades de melhorias do que apontar erros.

$O$ relatório deverá, em sua conclusão, indicar claramente se o Sistema de Gestão Ambiental do LRR está em conformidade com a Norma ISO 14001 (ABNT, 2004) ou outras normas adotadas.

É muito importante que exista uma completa observância da confidencialidade dos resultados, dados obtidos e informações de documento, processos, pontos fortes e pontos fracos do LRR, por questões éticas.

As auditorias ambientais, como qualquer outro tipo de auditoria, recolhem apenas amostras daquilo que é a situação real da organização, devido ao tempo limitado e às dificuldades de observação. É muito importante que a equipe de auditoria $e$, principalmente, os usuários das informações e resultados da auditoria, estejam conscientes das limitações e incertezas decorrentes desse processo, levando isso em conta na tomada de decisões que possam afetar os trabalhos da organização, recomendando-se uma análise mais aprofundada do problema quando houver dúvidas sobre assuntos muito importantes.

Após a análise do relatório e decisões gerenciais no sentido de implementar as correções e melhorias necessárias (corretivas ou preventivas, priorização das nãoconformidades quanto aos riscos ambientais, com designação de pessoal e liberação de recursos materiais e financeiros), é possível que a equipe de auditoria seja solicitada para realizar uma inspeção rápida para verificação das ações, emitindo-se um relatório resumido. Ou, por outro lado, se houver acordo prévio, o auditor poderá apresentar recomendações para a realização de ações corretivas às não-conformidades. 
Os formulários apresentados, a seguir, poderão ser utilizados para registrar elementos importantes associados às auditorias.

Tabela 4.5 - Modelo de Relatório Interno de Auditoria AUDITORIÄ INTERNA DO SGA DO LRR

Relatório $\mathrm{n}^{\circ}$

Data:

Área do LRR auditada:

Responsável pela área:

Finalidade e escopo da auditoria:

Período de realização:

Documentos de referência: .

Equipe de auditores:

Área auditada:

Nome:

Assinatura:
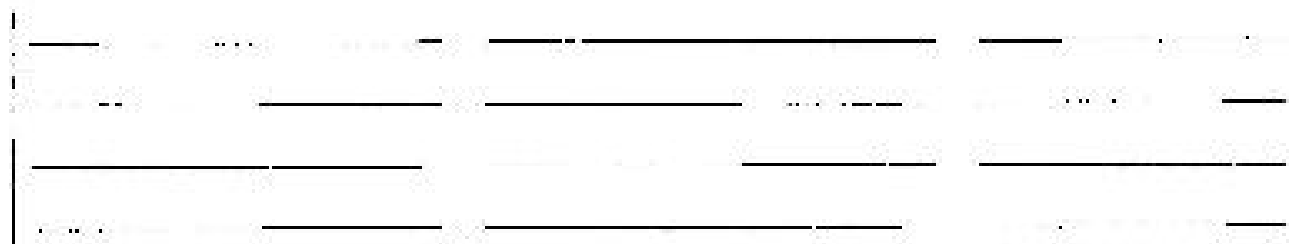

Preparado por:

Data:

Aprovado por:

Data: 
Tabela 4.6 - Modelo de Relatório de Acompanhamento de Auditoria

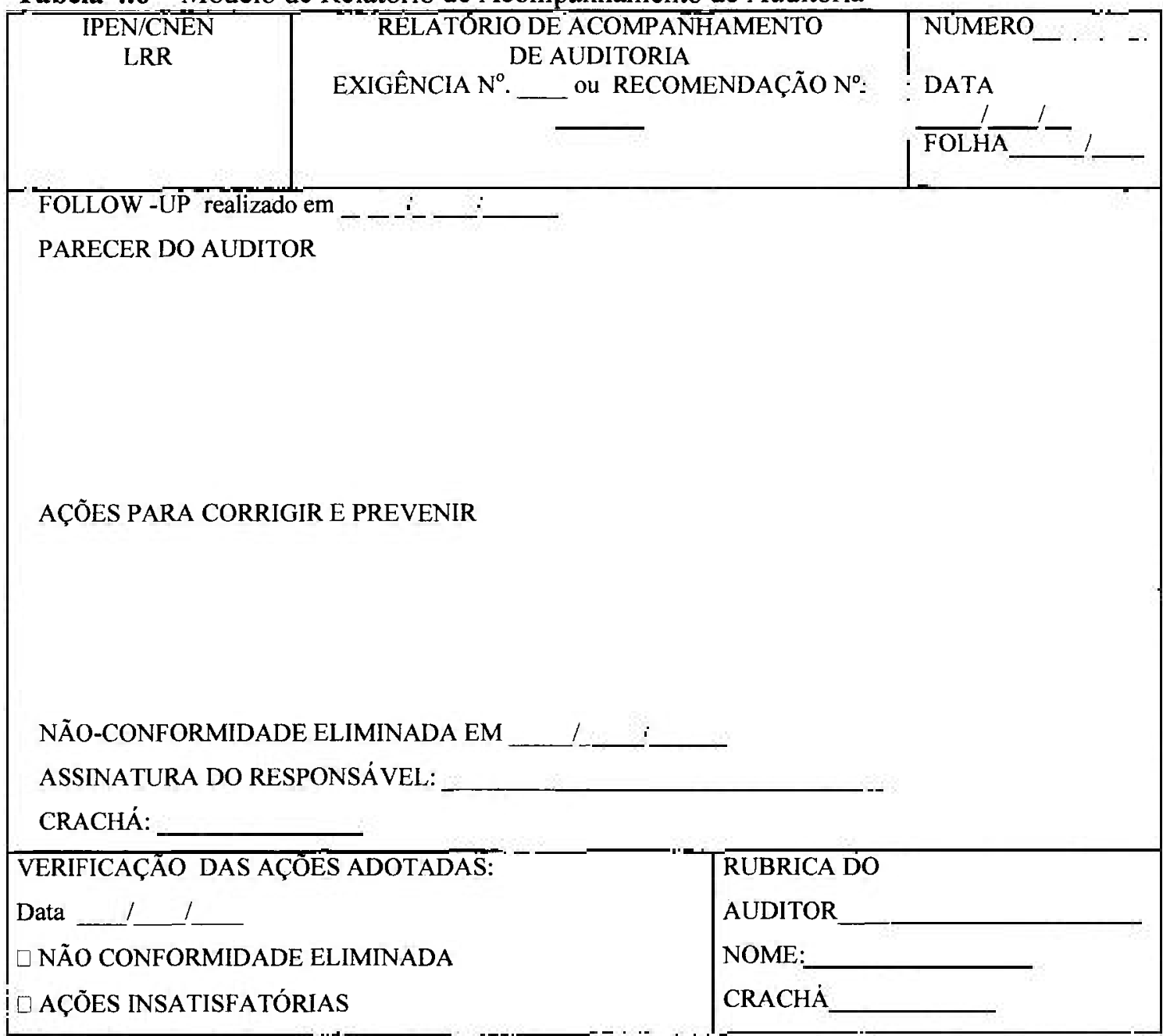


Tabela 4.7 - Relatório de Não-Conformidade Ambiental

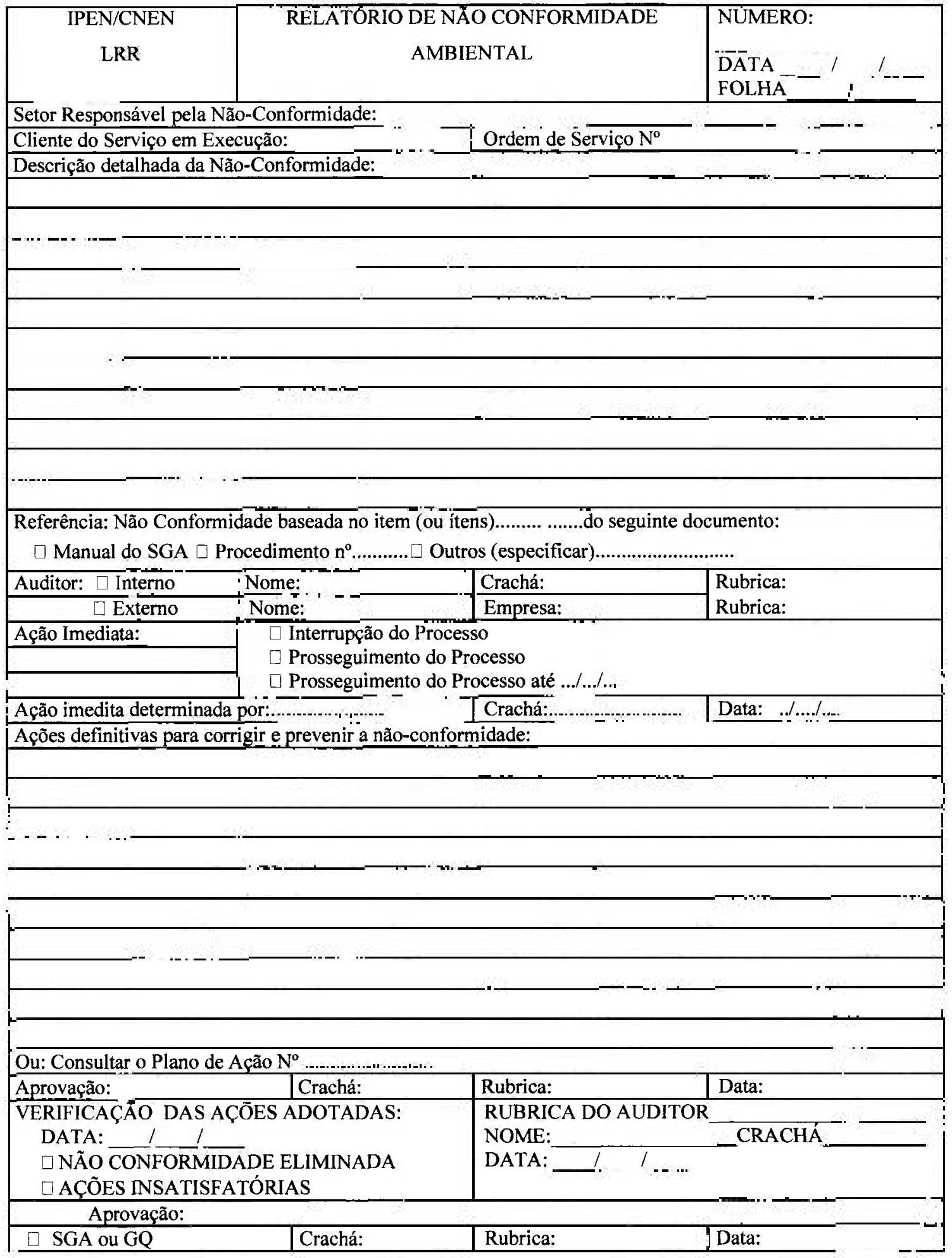




\subsection{Tratamento de não-conformidades}

Os desvios de procedimentos estabelecidos, que podem gerar impactos ambientais importantes, devem ser investigados, sendo tomadas ações de contenção, de correção e prevenção. As não-conformidades devem ser identificadas como resultado do trabalho e atuação de vários elementos constantes do SGA do LRR:

a) ações de monitoramento, medições e avaliações;

b) auditorias;

c) inspeções pela CNEN ou órgãos de controle ambiental;

d) análises críticas do SGA;

e) trabalhos de preparação e resposta em situações de emergência;

f) recebimento de comunicações internas ou externas.

As ações a serem tomadas, ao ser identificada uma não-conformidade, devem ser proporcionais à magnitude e importância dos impactos ambientais relacionados, reais ou potenciais. Poderá ser adotada a mesma classificação atribuída aos impactos, como por exemplo, catastrófica, crítica, marginal ou desprezível.

As não-conformidades que causem impactos marginais ou desprezíveis devem ser discutidas em reuniões e, com menor grau de formalismo, devem ser discutidas e implementadas as ações preventivas.

Atribuída uma classificação à não-conformidade, deve ser exercida uma ação de controle, voltada a eliminá-la ou a reduzir os impactos ambientais. Devem ser estabelecidas ações corretivas e, sempre que possível, estender o escopo dessa ação, de modo a ser realizada também uma ação preventiva

Para cada não-conformidade, devem ser identificadas as suas causas, ou causas potenciais, para que, eliminando-se as causas, seja anulada a não-conformidade e impedida a sua repetição. Uma das ferramentas mais interessantes para a identificação das causas é o Diagrama de Ishikawa, ou Diagrama de Causa-Efeito. Nele, são considerados os fatores 6M: Máquinas, Método, Medidas, Meio-ambiente, Mão-de-obra e Matérias primas. Deve existir um esforço para que seja identificada a "causa-raiz", que é a principal responsável pela ocorrência da não-conformidade. 
O dirigente principal do LRR deve realizar a verificação das eficácia das ações corretivas, com base em evidências objetivas, como, por exemplo, registros, relatórios, medições e entrevistas.

Para as não conformidades potenciais, ou seja, aquelas que não são baseadas na constatação de falhas, deverão ser estabelecidas ações preventivas. 


\subsection{PROGRAMAS DE GESTÃo ESPECÍFICOS}

Este tópico pretende apresentar algumas sugestões de implantação de programas de gestão específicos no LRR, aproveitando-se a estrutura montada para gestão ambiental, de forma a gerenciar com eficácia esses programas.

\subsection{Gestão de resíduos sólidos comuns}

Existindo resíduos sólidos, como resultado das atividades, haverá a necessidade de dar um destino a esses resíduos. O método tradicional de destinação consiste, na maioria das vezes, em sua colocação em aterros sanitários, aterros industriais e, muitas vezes, em lixões.

O problema vem se agravando cada vez mais em função do crescimento do volume do lixo, decorrente de mudanças de hábitos de consumo, com maior uso de alimentos processados e grande quantidade de embalagens. Existe, provavelmente uma maior conscientização com relação aos efeitos altamente negativos dos lixões: contaminação do solo, proliferação de vetores de doenças, contaminação de lençóis de água no subsolo, poluição visual, liberação de odores, entre outras conseqüências. A outra opção é a disposição em aterros, sanitários para o lixo orgânico e de limpeza pública e aterros industriais para os resíduos industriais.

A solução mais recomendada consiste em gerenciar, de forma integrada e adequada, o problema dos resíduos, reduzindo-se a sua geração e buscando-se estimular o reuso dos materiais, recuperação e reciclagem.

Resíduos domésticos (lixo): a solução mais efetiva será atingirmos melhores níveis de educação ambiental e de motivação das pessoas, para que elas modifiquem sua conduta. Será necessário que seja reduzido o consumo de certos materiais e embalagens (de plástico, por exemplo, substituindo-as por embalagens de papel e vidro), que seja aumentada a separação do lixo por tipos, para facilitar os processos de reciclagem. No LRR é muito pequena a contribuição desses resíduos.

Resíduos industriais: as melhores soluções passam pelos conceitos de "produção limpa", que envolve práticas gerenciais e industriais que buscam qualidade: prevenção da geração de resíduos, principalmente os perigosos e tóxicos; uso mais racional, com economia e parcimônia, de água e energia (já que quase todas as formas de 
produção de energia geram impactos ambientais significativos e a água, com qualidade, vem se tornando cada vez mais um bem escasso); uso sustentável de recursos naturais; emprego de práticas e possibilidades de reutilização, recuperação e reciclagem de materiais, melhor manutenção dos equipamentos; destino final da forma mais adequada e correta, dentro da melhor tecnologia disponível e adequada a cada tipo de resíduo.

É necessário conhecer cada material que entra e sai da instalação, suas propriedades químicas e físicas, realizar balanços de massas e conhecer o potencial de poluição de cada produto ou subproduto. Estudos relativamente simples poderão consolidar programas de reciclagem, separando-se os materiais por tipos e obtendo-se ganhos, desde que exista uma sustentabilidade econômica no processo. Esses inventários e auditorias, de verificação de conformidade à política da empresa e seus procedimentos formalizados, constituem-se em ferramentas valiosas para manter o sistema ativo e com posturas de melhoramento contínuo.

O tratamento e a disposição de resíduos constituem-se, na maioria dos casos, em atividades complexas e caras, razões para se procurar a minimização de sua geração e redução de seus impactos sobre o meio ambiente.

A menor geração proporciona economia de despesas com transporte e armazenamento e também aumentam a segurança, proteção e saúde dos empregados. Os procedimentos para redução devem prever as atividades de todos os envolvidos, prevendose:

- tomar precauções com o armazenamento e transporte;

- avaliar as economias obtidas e estabelecer um sistema de alocação de custos para os resíduos gerados;

- estudar a quantidade mínima de matérias primas a ser estocada, com a finalidade de reduzir volumes e áreas de almoxarifado, com todas as vantagens ambientais decorrentes disso (redução de espaços de armazéns, redução de ar condicionado, redução de emissões fugitivas, etc.);

- promover avaliações periódicas dos resultados alcançados e fixação de novas metas.

Outras sugestões visando reduzir a geração de resíduos são:

- identificar os resíduos e efluentes descartados (caracterização dos componentes, em termos de composição química, quantidades, conseqüências ambientais) e identificar os processos industriais que geraram aqueles produtos. Com o conhecimento obtido, estudar modificações nos processos (ou nas matérias primas) mais impactantes; 
- procurar reduzir os riscos causados pelos resíduos, estudando-os quanto à sua toxicidade, flamabilidade, reatividade, corrosividade e radioatividade, preparando-se melhor os funcionários no seu manejo, fornecendo equipamentos de proteção individual adequados, preparando procedimentos a serem rapidamente cumpridos em situações de emergência, entre outras ações. Procurar modificar os processos industriais e a matéria prima, de modo que não resultem resíduos com estas características. Restringir e controlar o acesso a estes materiais perigosos;

- estudar as origens da matéria prima, como ela é obtida na natureza, o método de extração caso se trate de algum minério, sua armazenagem e seu uso na organização. Estudar a possibilidade de melhorar algumas dessas fases;

- evitar, caso existam alternativas, o uso de matérias primas que sejam tóxicas ou apresentem outros tipos de perigo (serão reduzidos os riscos de contaminação dos trabalhadores e aumentada a segurança do trabalho. Banir matérias primas de uso proibido pela legislação);

- não usar transformadores cujo fluido isolante seja um PCB (bifenila policlorada), conhecido como ascarel. Substituir aqueles existentes, que usem este produto, enviando-os para incineração;

- evitar gerar resíduos cujo processo de destinação final envolva altos custos, por exemplo, alguns resíduos que somente podem ser incinerados, em condições especiais, com elevado controle de emissões atmosféricas;

- procurar usar produtos de limpeza menos agressivos ao meio ambiente. Evitar usar solventes químicos, dando preferência a solventes não tóxicos, renováveis, de preferência não orgânicos ou, melhor ainda, solventes à base de água, se possivel. Não usar hidrocarbonetos clorados como solvente para limpeza;

- desenvolver métodos de trabalho que reduzam o uso de papel, estimulando-se o uso de correio eletrônico ou arquivos de dados em forma magnética;

Outra postura a ser adotada no LRR refere-se à reciclagem dos resíduos.

Existem grandes vantagens em realizar a reciclagem, sobretudo por poupar recursos e evitar a disposição inadequada, entre as quais podemos citar:

- trata-se de um processo que reduz a quantidade de materiais que seriam destinados a lixões ou aterros (problemas de saturação dos espaços);

- são evitados os custos com a disposição do lixo; 
- proporciona empregos a uma quantidade muito grande de pessoas, com baixíssima qualificação, que teriam imensas dificuldades em encontrar outra forma de trabalho; e

- permite a economia de recursos naturais e de energia.

Os principais materiais recolhidos no lixo são: restos de alimentos, papel e papelão, metais, borracha e couro, madeira, restos de jardinagem, vidro, plástico, têxteis. Sugere-se que seja implementado no LRR um processo de coleta seletiva, cobrindo os seguintes tipos de materiais:

a) papel: separação em papel de jornal, corrugados, livros, revistas, toalhas de papel, papel de escritório, folhetos, papel de embrulho;

b) vidro: garrafas de vidro(transparente, verde, marrom), outros vidros;

c) metais: latas de alumínio, folhas de alumínio, ferrosos, estanho;

d) plásticos: PET, poliestireno, PEAD, (polietileno de alta densidade) PVC (cloreto de polivinila).

O lixo orgânico continuaria a ser retirado e gerenciado pelo IPEN.

A administração do LRR deverá estabelecer a infra-estrutura interna necessária à coleta de resíduos sólidos e materiais para reciclagem, definindo os pontos de coleta $\mathrm{e}$ acessórios necessários, armazenamento e forma de destinação correta.

Deverão ser mantidos registros referentes ao transporte e disposição de resíduos perigosos. Deverá ser previsto um controle sobre as empresas contratadas para reciclagem ou eliminação de resíduos.

\subsection{Gestão do uso da energia}

Energia é um bem essencial em todas as atividades produtivas e de serviço e sua geração quase sempre provoca impactos ambientais significativos. Esse motivo, aliado ao seu custo, cada vez mais elevado, justifica a adoção de planos específicos de uso racional da energia, ou "economias" de energia. O uso racional não significa deixar de usar a energia quando dela se necessita, ou seja, manter ambientes mal iluminados, deixar de usar refrigeração ou aquecimento, mas sim, modificar processos para evitar desperdícios, realizar ajustagens de máquinas para melhorar a sua eficiência energética, melhorar os processos arquitetônicos para utilizar iluminação natural (o que agrada muito mais aos usuários dos ambientes, aumentando inclusive a produtividade das pessoas), melhorar o isolamento térmico em ambientes aquecidos ou refrigerados para evitar perdas, entre outras possíveis medidas de economia: 
Entre as possíveis medidas a serem adotadas pelo LRR quanto ao uso de energia, podem ser citadas:

a) avaliar os motores elétricos existentes, quanto ao seu consumo;

b) substituição de lâmpadas incandescentes por fluorescentes;

c) substituição de reatores comuns por reatores eletrônicos (menor aquecimento e menor consumo);

d) avaliação da cabeação elétrica quanto a aquecimento (perdas e risco);

e) verificação do fator de potência das instalações.

\subsection{Gestão do uso de água}

A água de qualidade constitui-se, atualmente, em um bem de grande valor e importância.

O LRR não é um usuário de volumes significativos de água, porém todos os esforços devem ser tomados para assegurar seu uso racional. Devem ser verificados os consumos nos equipamentos, estudadas as possibilidades de reúso e reciclagem, exercido um controle sobre vazamentos, entre outras ações possíveis.

O descarte de águas residuais deverá ser feito após análise, quando houver suspeita de contaminação, observando-se os valores limite de lançamento previstos na legislação. Estas águas somente poderão ser descartadas após serem submetidas a sistemas de tratamento.

Suspeitando-se da ocorrência de contaminação do solo ou lençol freático, deverão ser feitas sondagens e, se necessário, empreendidas medidas de correção. $\mathrm{O}$ processo e o resultado das medidas corretivas deverão ser controlados periodicamente. 


\section{CONCLUSÕES}

A Norma Internacional ISO 14.001 - Sistemas de Gestão Ambiental, apresenta os requisitos a serem observados pelas organizações preocupadas em atingir e demonstrar um desempenho ambiental mais aprimorado. Essas organizações, principalmente as industriais e de serviços, visam controlar os impactos de suas atividades, produtos e serviços sobre o meio ambiente, levando em conta suas políticas e objetivos ambientais.

Esta dissertação procurou interpretar os requisitos da Norma ABNT ISO 14.001, sugerindo procedimentos e um modo de trabalho, de forma a facilitar o cumprimento desses requisitos pelas organizações que buscam certificação ou, tão somente, melhorar seu desempenho ambiental, independentemente de seu porte e tipo.

O Laboratório de Rejeitos Radioativos (LRR) do IPEN pode ser considerado uma instalação de referência para o tratamento e a armazenagem de rejeitos radioativos de atividades baixa e média, provenientes de outras unidades do IPEN, além de rejeitos radioativos oriundos de indústrias, clínicas e outras instituições externas, principalmente das regiões sul e sudeste do país. Verifica-se que, com o crescente uso da energia nuclear, há uma tendência de aumento desse tipo de rejeito.

Como um estudo de caso, esta dissertação procurou particularizar as sugestões aplicáveis às organizações em geral, adaptando-as para o Laboratório de Rejeitos Radioativos do IPEN. Os pontos considerados mais trabalhosos referem-se à identificação dos aspectos e impactos ambientais, à preparação de um sistema de documentação, as atividades de treinamento e obtenção de uma cultura de segurança e à implantação de um processo de auditorias.

Acreditamos que este trabalho poderá orientar e facilitar a implementação da Norma ISO 14001 nesse Laboratório, caso a Alta Administração julgue necessário e conveniente obter uma certificação desse tipo. Existem muitas vantagens em adotar esse procedimento, o principal delas consistindo na redução de riscos ambientais.

O reconhecimento da Sociedade e de outros Órgãos Governamentais também é um fator importante a ser considerado, justificando a adoção das sugestões contidas neste trabalho. 


\section{REFERÊNCIAS BIBLIOGRÁFICAS}

ASSOCIAÇÃO BRASILEIRA DE NORMAS TÉCNICAS. Diretrizes para auditoria ambiental. Princípios gerais ABNT NBR ISO 14010 (Norma superada). 1996.

ASSOCIAÇÃO BRASILEIRA DE NORMAS TÉCNICAS. Diretrizes para auditorias de sistema de gestão da qualidade e/ou ambiental. ABNT NBR ISO 19011. Novembro 2002.

ASSOCIAÇÃO BRASILEIRA DE NORMAS TÉCNICAS. Sistemas de Gestão Ambiental - Requisitos com orientações para uso. ABNT NBR ISO 14401. $2^{\text {a }}$ edição, 31.12.2004.

BRUNDTLAND, G.H. et all; "Our Common Future", Report of the World Commission on Environment and Development; A/42/427; United Nations Organization; Aug 1987.

CENTRO TECNOLÓGICO DA MARINHA EM SÃO PAULO. Centro Experimental Aramar. Relatório de Impacto Ambiental - RIMA. Multiservice Engenharia. Revisão Final. Setembro de 1997.

CLARKE, R.H. Environmental Radioactivity. The Development of the ICRP Philosophy. In: Protection of the Environment from the Effects of Ionizing Radioation. Proceedings of an International Conference, IAEA, Proceedings...Stockholm 3-10 October 2003. Disponível em: <http://wwwpub.iaea.org/MTCD/publications/PDF/Pub1229_web.pdf>. Acesso em 22.5.2007.

CNEN - COMISSÃO NACIONAL DE ENERGIA NUCLEAR. Gerência de Rejeitos Radioativos em Instalações Radiativas. (CNEN-NE-6.05). Dezembro de 1985.

CNEN - COMISSÃO NACIONAL DE ENERGIA NUCLEAR. Licenciamento de Instalações Radiativas (CNEN-NE-6.02). Julho de 1998.

CNEN - COMISSÃO NACIONAL DE ENERGIA NUCLEAR. Seleção e Escolha de Locais para Depósitos de Rejeitos Radioativos. (CNEN, NE - 6.06). Dezembro de 1989.

CNEN. COMISSÃO NACIONAL DE ENERGIA NUCLEAR Artigo Rejeitos Radioativos. Coordenação-Geral de Relações Institucionais. Divisão de Comunicação Social. Rio de Janeiro, novembro de 2001.

CNEN. COMISSÃO NACIONAL DE ENERGIA NUCLEAR. Critérios de Aceitação para Deposição de Rejeitos Radioativos de Baixo e Médio Níveis de Radiação. (CNEN-NN-6.09). Setembro de 2002.

CNEN. COMISSÃO NACIONAL DE ENERGIA NUCLEAR. Licenciamento de Instalações Nucleares. Norma CNEN-NE-1.04. Dezembro de 2002. 
COMMISSARIAT A L'ENERGIE ATOMIQUE. CEA. Le Traitement du combustible usé : une filière bien maîtrisée. Disponível em $<$ http://www.cea.fr/var/plain/storage/original/application/77eb3b12b94d00326f3f8d830 ce2dba3.pdf>. Acesso em 3.12.2007.

COMMISSARIAT A L'ENERGIE ATOMIQUE. CEA Des neutrons pour la recherche et la gestion des déchets nucléaires. 31.1.2007. Disponível em http://www.cea.fr/presse/liste_des_communiques/experience_megapie. Acesso em 4.12.2007.

DEPARTMENT OF ENERGY OF U.S.A. Energy Outlook 2007, May 2007.

Disponível em http://www.eia.doe.gov/oiaf/ieo/pdf/0484(2007). Acesso em 5.12.2007.

ELETRONUCLEAR. Apostila TEG - Treinamento dos Empregados em Geral. Apostila de Cultura de Segurança. Divisão de Treinamento, 2000.

INTERGOVERNMENTAL PANEL ON CLIMATE CHANGE. Working Group III. Fourth Assessment Report. Climate Change 2007: Mitigation of Climate Change. Summary for Policymakers. 4 May 2007. Disponível em:

<http://www.ipcc.ch/SPM040507.pdf>. Acesso em 9.5.2007.

INTERNATIONAL ATOMIC ENERGY AGENCY. Principles of Radioactive Waste Management, IAEA Safety Series no. 111-F. IAEA, Viena, 1995.

INTERNATIONAL ATOMIC ENERGY AGENCY. Joint Convention on the Safety of Spent Fuel Management and on the Safety of Radioactive Waste Management. INFCIRC/546. 24.12.1997.

NTERNATIONAL ATOMIC ENERGY AGENCY. - The Long Term Storage of Radioactive Waste: Safety and Sustainability - A Position paper of International Experts. Viena, 2003.

Disponivel em: http://www-pub.iaea.org/MTCD/publications/PDF/LTS-RW_web.pdf. Acesso em 5.12.2007.

INTERNATIONAL ATOMIC ENERGY AGENCY. Radiation, People and the Environment. Viena. February, 2004. Disponível em:

$<$ http://www.iaea.org/Publications/Booklets/RadPeopleEnv>. Consultado em 3.5.2007.

INTERNATIONAL ATOMIC ENERGY AGENCY. Management Systems. IAEA Safety Standard Series. DS 338 Draft 6. Viena, 25.8.2004.

INTERNATIONAL COMISSION ON RADIOLOGICAL PROTECTION. ICRP Recommendations on radiological protection. 2007. Disponivel em:

<http://www.icrp.org/>. Acesso em 9.5.2007.

INTERNATIONAL NUCLEAR SAFETY CENTER. Nuclear reactors. Disponível

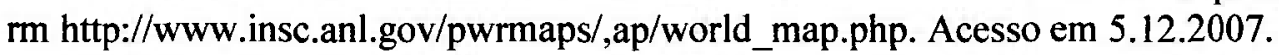

JURAN, J.;GRYNA, F. Juran's Quality Control Handbook. 4.ed. New York, McBraw-Hill, 1988. 
LONG, M.E. Meia-Vida. A Herança Letal do Lixo Nuclear Americano. Revista National Geographic Brasil , julho, 2002.

MINISTÉRIO DE MINAS E ENERGIA. Balanço Energético Nacional 2005, Secretaria de Energia, Ministério de Minas e Energia, Brasilia, DF, 2005. Disponível em: <http://www.mme.gov.br>. Acesso em 5.5.2006.

MOREIRA, J.M.L; ABE, A.Y. Energia Nuclear e os Rejeitos Radioativos. XI Congresso Brasileiro de Energia. Rio de Janeiro - Rio de Janeiro, 16 a 18 de agosto de 2006.

MOURA, L.A.A. Qualidade e Gestão Ambiental. $4^{\text {a }}$ Ed. São Paulo, Editora Juarez de Oliveira, 2004.

NASA - NATIONAL AEROSPACE AND SPACE ADMINISTRATION. Visão noturna da Terra. Disponível em: http://apod.nasa.gov/apod/ap001127.html. Acesso em 5.12.2007.

NATIONAL GEOGRAPHIC BRASIL. Revista mensal de informações. São Paulo. Editora Abril, Ano 3 n.27, julho 2002, 138 p.

OBADIA, I.J; VIDAL, M.C.R; Melo, P.F.F.F. A Total Safety Management Model. Contributed papers. International Conference on Safety Culture in Nuclear Installations, p. 71. IAEA. Rio de Janeiro, 2-6 December 2002.

ROMANATO, L.S. Armazenagem de Combustível Nuclear "Queimado". Dissertação de Mestrado. Orientada pela Profa. Dra. Bárbara M. Rzyski. IPEN, 2005.

SORDI, G.M.; TODO, A.S. Apostila do curso Fundamentos de Tecnologia Nuclear - Proteção Radiológica. IPEN, 2004.

TERREMOTO, L.A.A. Apostila Fundamentos de Tecnologia Nuclear. Reatores. Disciplina TNR-5764. IPEN, 2004.

U.S. NUCLEAR REGULATORY COMMISSION - 10 CFR Part 61 - Licencing Requirements for Land Disposal of Radioactive Waste. Disponível em: http://www.nrc.gov/reading-rm/doc-collections/cfr/part061/full-text.html. Acesso em 4.12.2007. 